\title{
TOOLS FOR FINANCING LOCAL BICYCLE AND PEDESTRIAN IMPROVEMENTS: MOVING FROM PLANNING TO \\ IMPLEMENTATION IN A FISCALLY \\ CONSTRAINED ENVIRONMENT
}

\author{
A Thesis \\ presented to \\ the Faculty of California Polytechnic State University, \\ San Luis Obispo
}

\author{
In Partial Fulfillment \\ of the Requirements for the Degrees \\ Master of City \& Regional Planning \\ Master of Science in Engineering (Transportation Planning Specialization) \\ by \\ Elissa McDade \\ December 2014
}




\section{(C) 2014 \\ Elissa McDade \\ ALL RIGHTS RESERVED}




\section{COMMITTEE MEMBERSHIP}

TITLE:

Tools for Financing Local Bicycle and Pedestrian Improvements: Moving from Planning to Implementation in a Fiscally Constrained Environment

AUTHOR: Elissa McDade

DATE SUBMITTED: $\quad$ December 2014

COMMITTEE CHAIR: Dr. William W. Riggs, Assistant Professor

City \& Regional Planning Department

COMMITTEE MEMBER: Dr. W. David Conn, Professor

City \& Regional Planning Department

COMMITTEE MEMBER: Menka Sethi, Adjunct Professor

Orfalea College of Business 


\begin{abstract}
Tools for Financing Local Bicycle and Pedestrian Improvements: Moving from Planning to Implementation in a Fiscally Constrained Environment

\section{Elissa McDade}

Communities across the United States, of all sizes, have accepted that maintaining the automobile-centric design of their cities is not a sustainable way to plan for the future growth, public health or safety of their cities or citizens. As a result, communities have begun to embrace a shift in their design and engineering standards to allow for pedestrian and bicycle friendly facilities that safely accommodate and encourage mode choice. Through the collective will of the public and city leadership, communities are rapidly moving toward implementing plans and design standards that re-establish the public right of way as safe and accessible for pedestrians and bicyclists, as well as automobiles.

However, in the face of increasingly diminished federal and state transportation funding, cities are looking toward creative local funding mechanisms to pay for their bicycle and pedestrian infrastructure. To understand the types of local funding being used, this thesis analyzes eleven different sized case study cities across the U.S. that are leaders in planning for, and implementing, multimodal capital projects and programs.

These national leaders most widely used the county sales tax measure as a funding mechanism. Additional popular approaches were bond issues, general fund allocations, and transportation impact fees. The case study analysis also 
revealed that cities often looked to more than one local funding source to fund their bicycle and pedestrian capital projects. 


\section{ACKNOWLEDGMENTS}

I would like to thank my thesis committee for your help guiding and shaping the final product. A special thank you goes to Dr. Riggs for his hours of patient and enthusiastic guidance and support. Additionally, thank you to my family for your unceasing support throughout my thesis writing process.

I would also like to thank Nicole Wynands and The League of American Bicyclists for providing 2012/2013 Bicycle Friendly Community data. 


\section{TABLE OF CONTENTS}

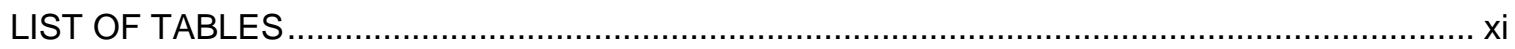

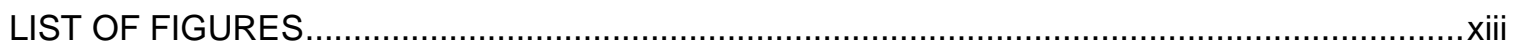

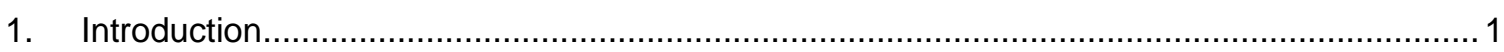

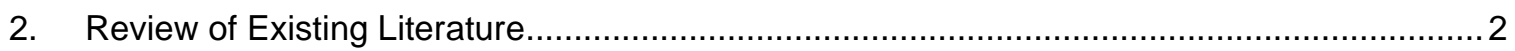

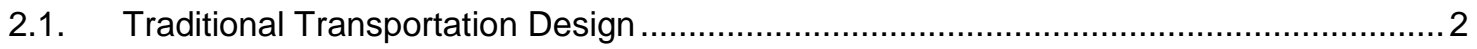

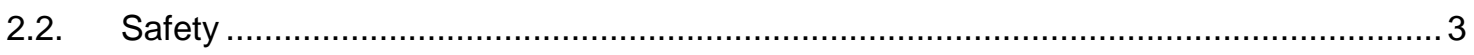

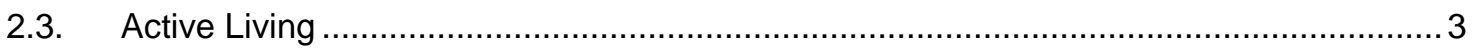

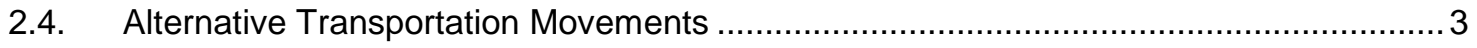

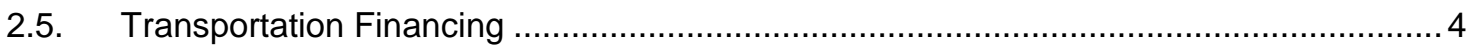

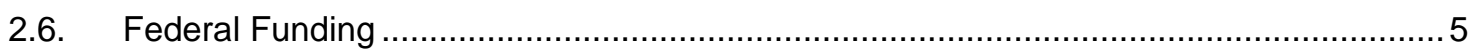

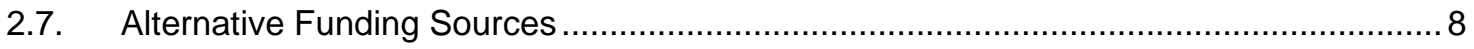

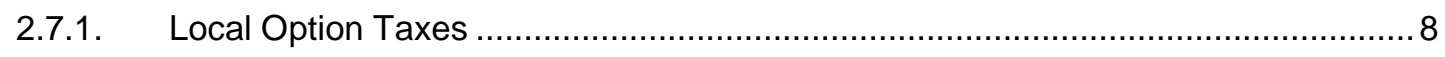

2.7.2. Developer Requirements and Parking Revenues ........................................... 8

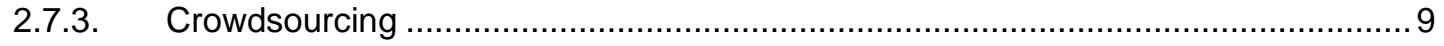

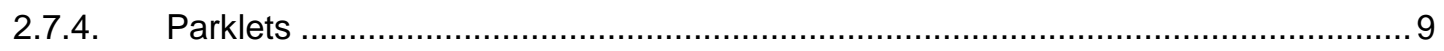

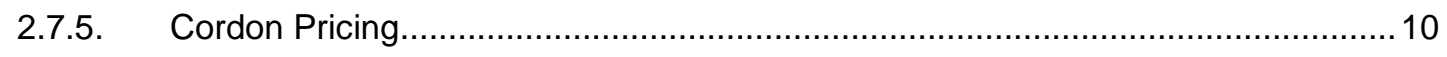

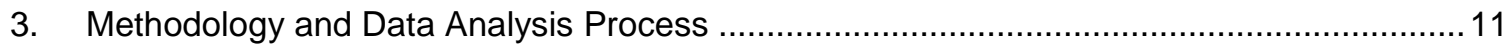

3.1. Proposition and Secondary Research Questions ................................................11

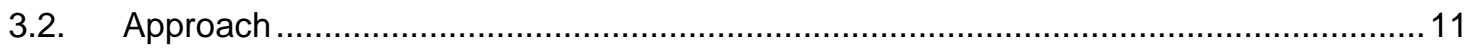

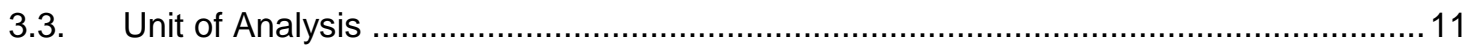

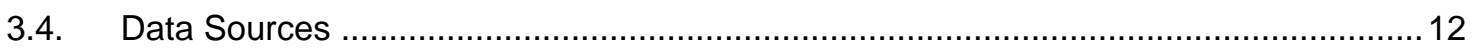

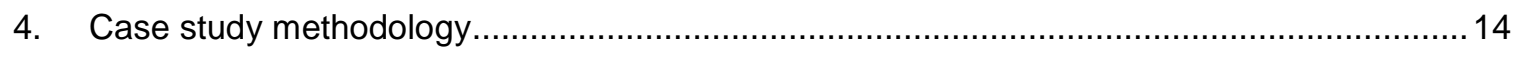

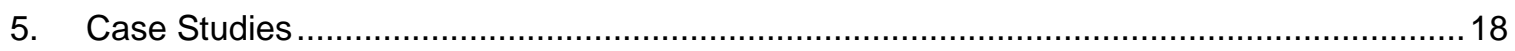

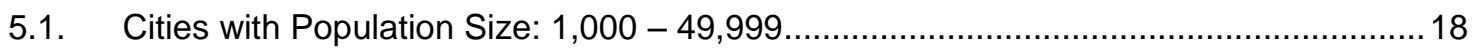




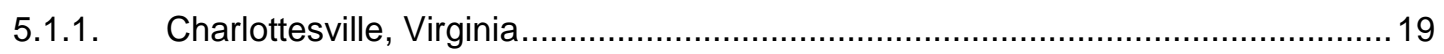

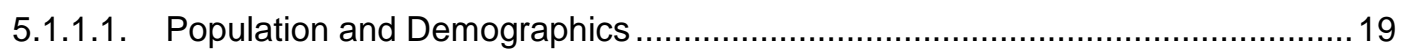

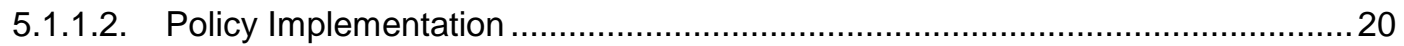

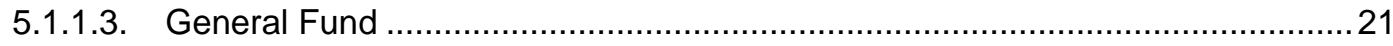

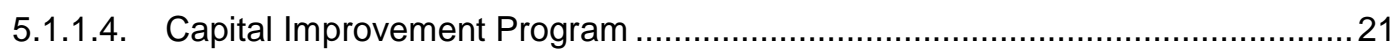

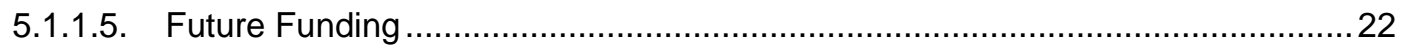

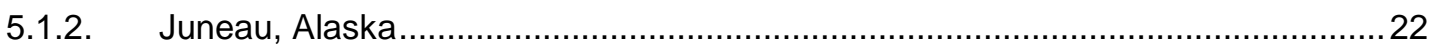

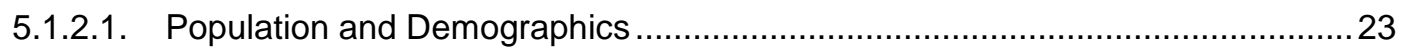

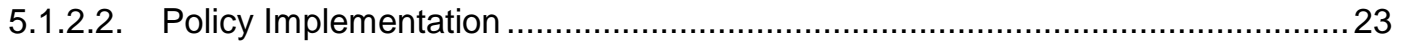

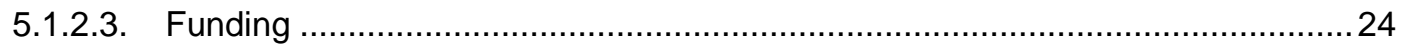

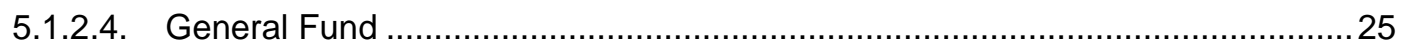

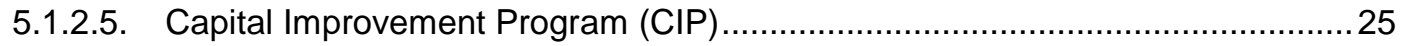

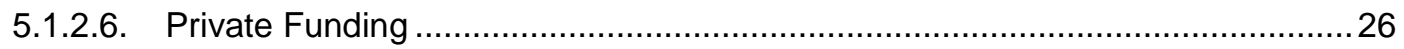

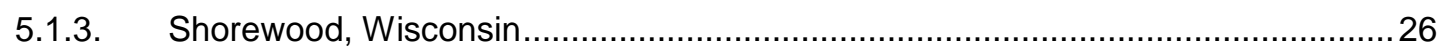

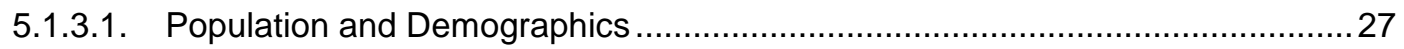

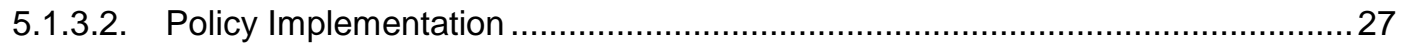

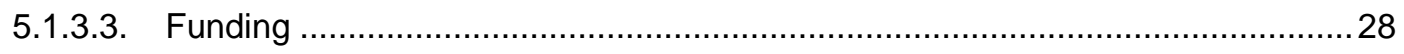

5.2. Cities with Population Size: 50,000 - 99,999..................................................... 30

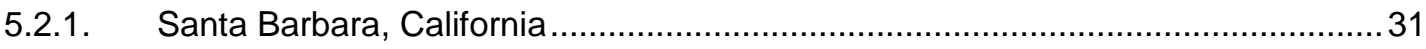

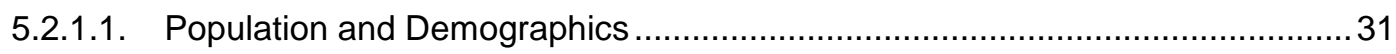

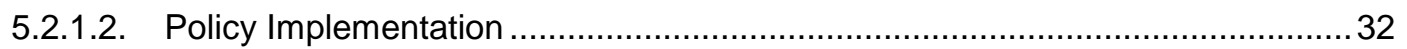

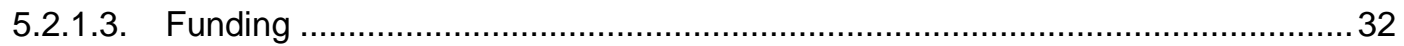

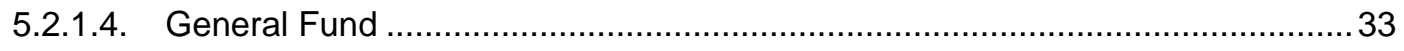

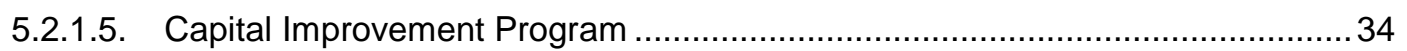

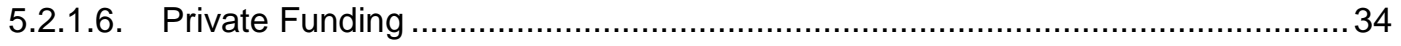

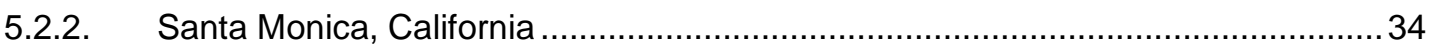

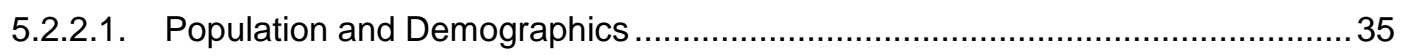

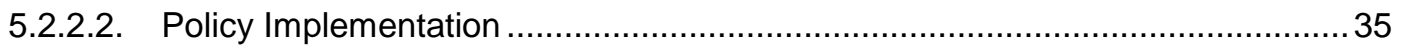


5.2.2.3. General Fund, Special Revenue Fund and Private Funding

5.3. Cities with Population Size: 100,000 - 299,999................................................. 38

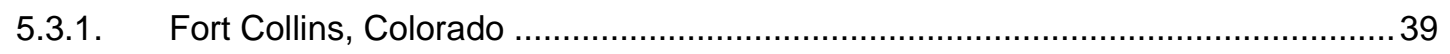

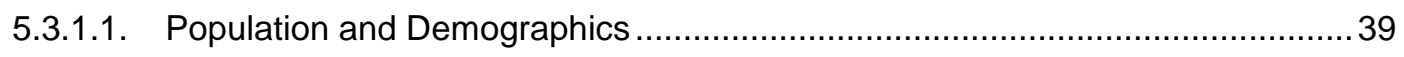

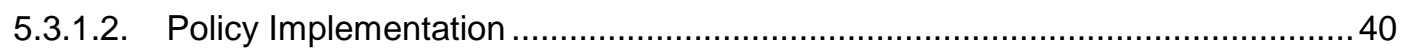

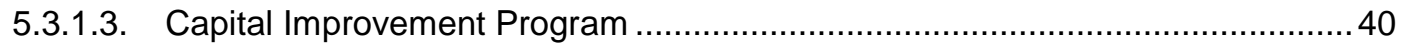

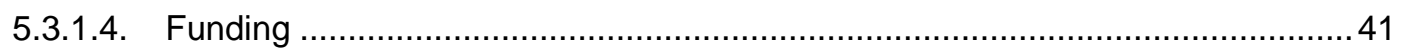

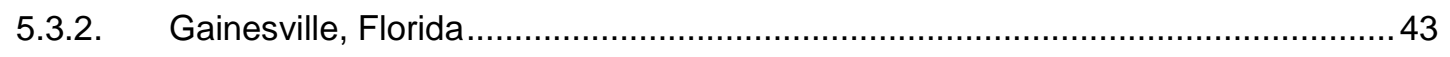

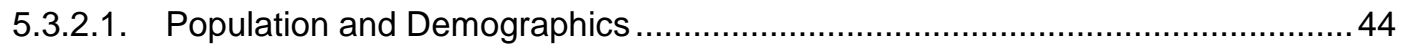

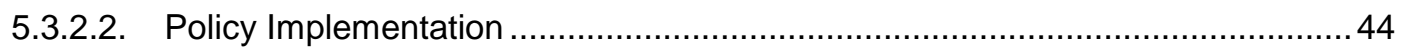

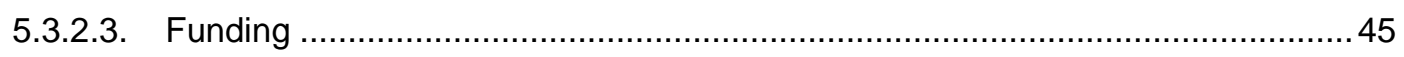

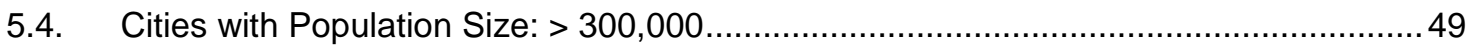

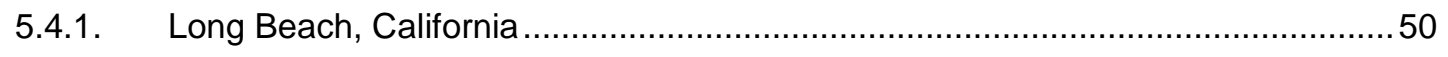

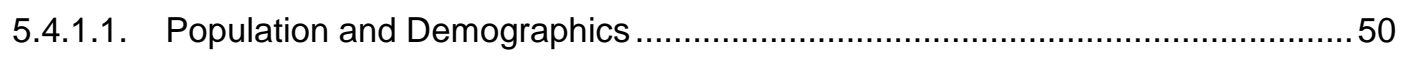

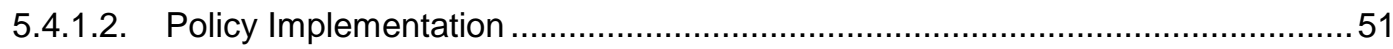

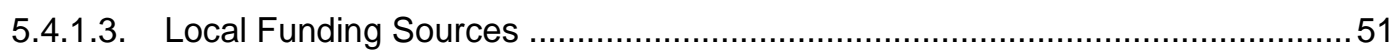

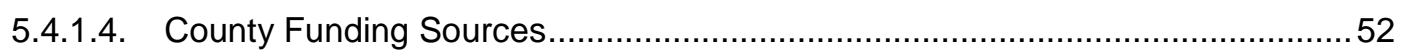

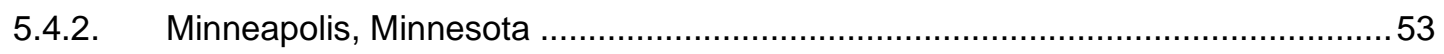

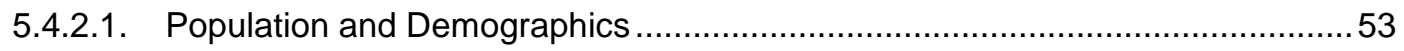

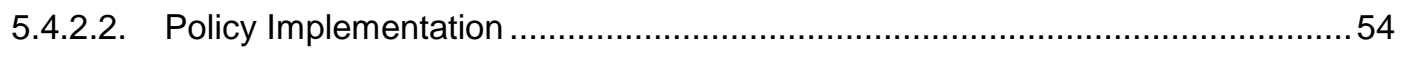

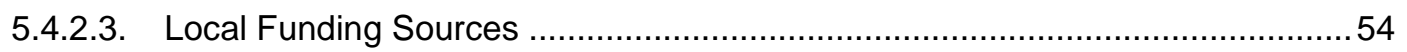

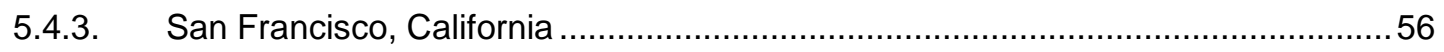

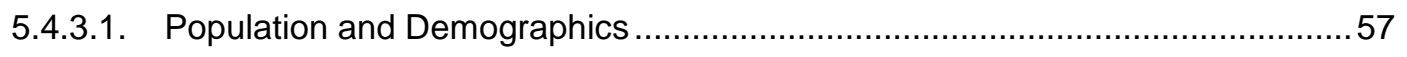

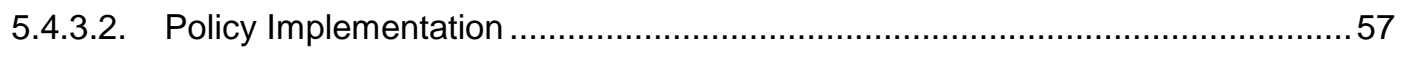

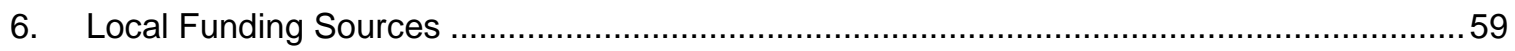

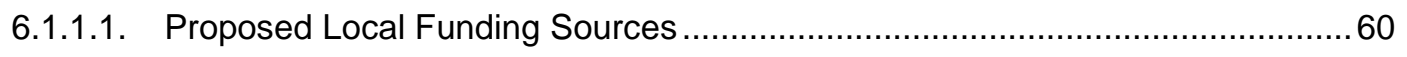

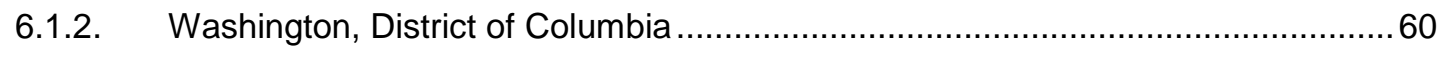

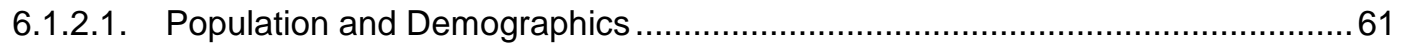




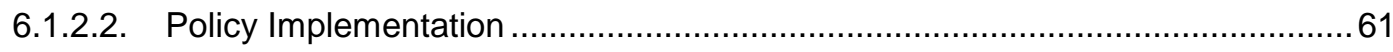

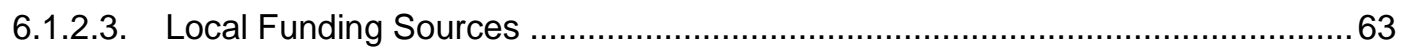

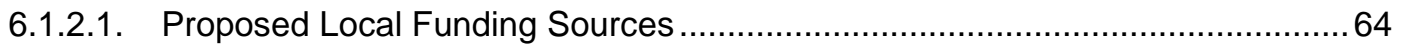

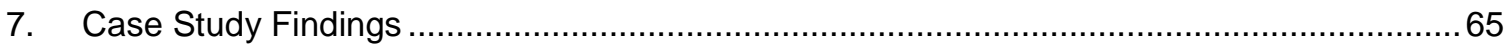

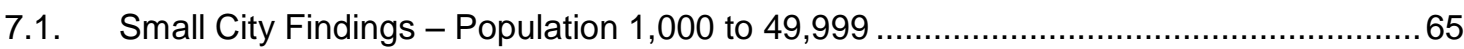

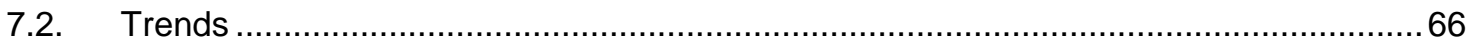

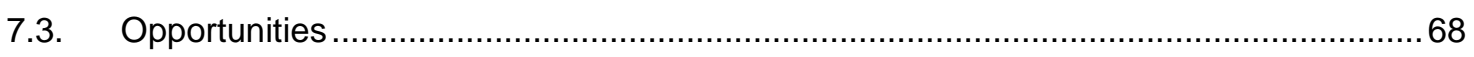

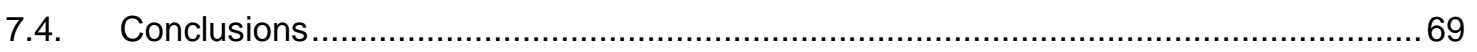

8. Additional Conclusions, Recommendations and Further Study ........................................ 70

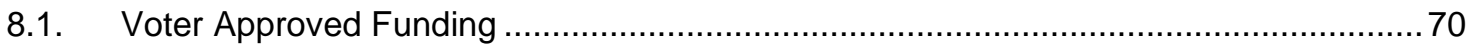

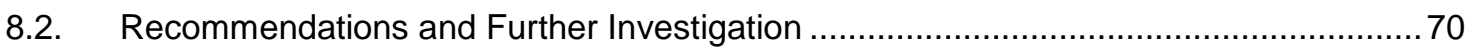

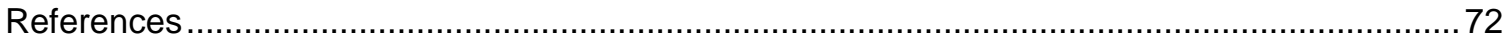




\section{LIST OF TABLES}

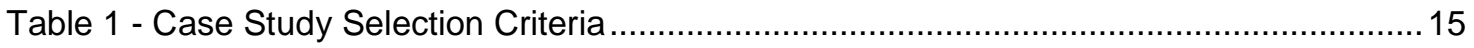

Table 2 - City Scoring Matrix for size 1,000 - 49,999 ....................................................... 18

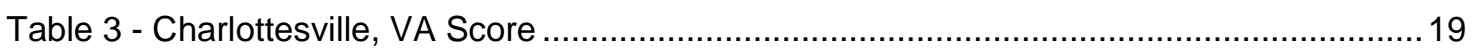

Table 4 - City of Charlottesville, VA Capital Improvement Funds, FY 2014 Budget Cycle .......22

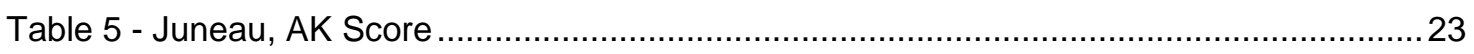

Table 6 - Juneau Programming Projects Reviewed, FY 2012 - 2015 .................................... 24

Table 7 - Juneau CIP, Bicycle and Pedestrian Capital Projects, FY 2015 ..............................26

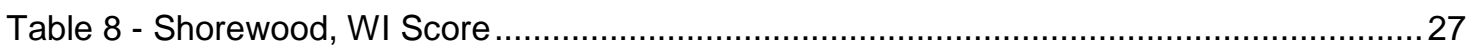

Table 9 - City Scoring Matrix for Population Size 50K - 99,999 …....................................... 30

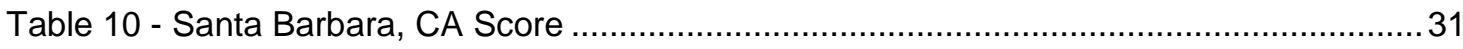

Table 11 - Measure A Program of Projects - City of Santa Barbara, FY 2014/15 .................... 33

Table 12 - City of Santa Barbara Capital Budget FY 2015 - Bicycle and Pedestrian

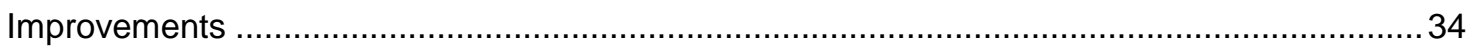

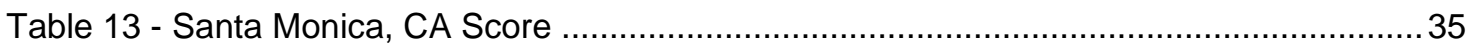

Table 14 - City of Santa Monica Relevant CIP Projects FY 2014-16 …................................ 37

Table 15 - City Scoring Matrix for Population Size 100K - 299,999 ….................................. 38

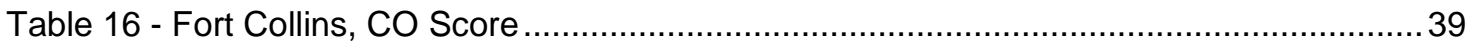

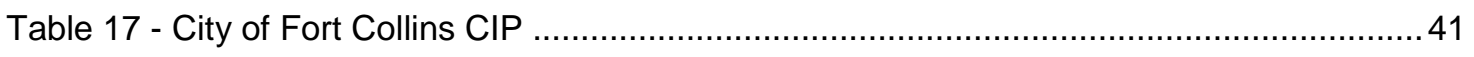

Table 18 - City of Fort Collins - Funded and Approved Projects Budget Years 2015-2016 ...... 42

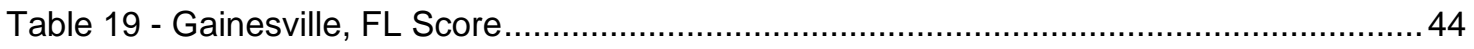

Table 20 - City of Gainesville FY 2013 - 2014 General Funds (unique funding sources) ......... 45

Table 21 - City of Gainesville - 5 Year Schedule of Bicycle and Pedestrian Capital

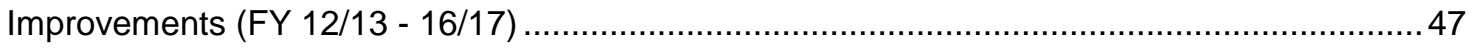

Table 22 - City Scoring Matrix for Population Size > 300,000 …........................................ 49

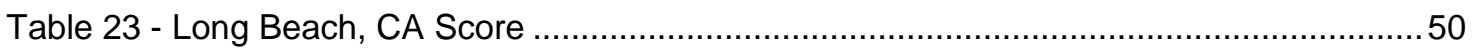

Table 24 - FY 2014 CIP Program Transportation Enhancements - Bicycle, Pedestrian and

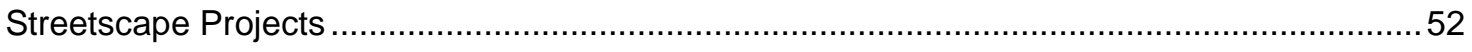


Table 25 - FY 14 Successor Agency CIP - Bicycle, Pedestrian and Streetscape Projects ........52

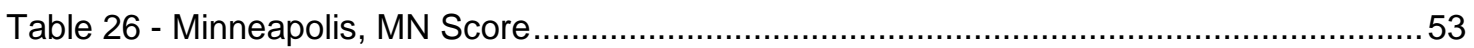

Table 27 - City of Minneapolis 5 Year Capital Investment Allocation (FY 14 Adopted Budget):

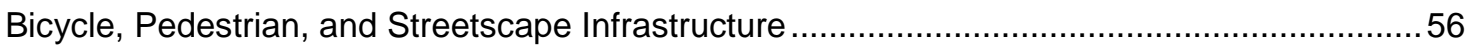

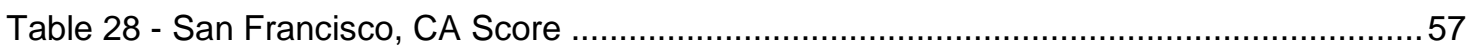

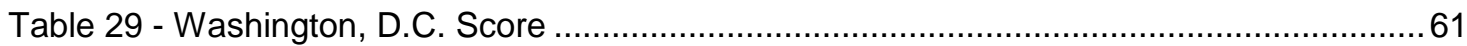

Table 30 - District of Columbia Bicycle and Pedestrian Capital Projects - Proposed Local

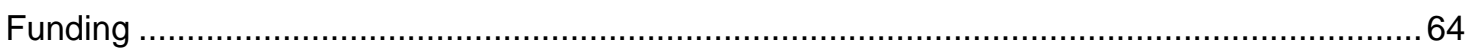

Table 31 - Small City Existing Local Bicycle and Pedestrian Funding Mechanisms .................65

Table 32 - Existing Local Bicycle and Pedestrian Funding Mechanisms by Population Group 67

Table 33 - Existing Local Bicycle and Pedestrian Funding Mechanisms by Local Funding

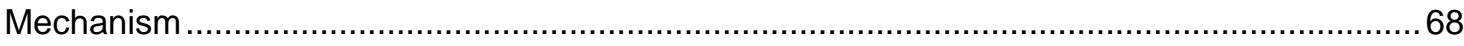




\section{LIST OF FIGURES}

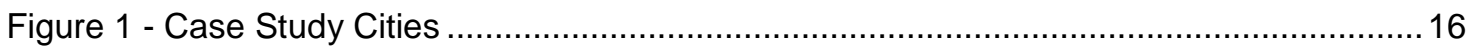




\section{Introduction}

Cities across the U.S. have embraced a shift in their design and engineering standards toward streetscapes that safely accommodate and encourage mode choice. However, they are facing funding shortfalls, due, in part, to stagnating gasoline tax revenue, more fuel efficient vehicles, and a decline in vehicle miles traveled. As a result, local communities are often left to compete with one another for available state and federal dollars. At the local level, many communities are deferring capital projects, such as signal modernization and roadway widening, due to a decline in funding. Without complete state and federal funding assistance, financing of planned and designed bicycle and pedestrian capital projects is placed at a low priority for implementation. As state and federal funding sources also become less abundant, communities need alternative approaches to finance bicycle and pedestrian facilities in a way that allows those projects to be implemented in a reasonable timeframe.

This thesis analyzes national leaders in bicycle and pedestrian infrastructure, policy, and program implementation to attempt to identify the most widely used funding. Through the review of funding sources, funding dollar amounts, community census data, existence of bicycle and/or pedestrian master plans, project implementation framework, and responsible staff from a case study sample, narrowed from a larger grouping of thirty-six different-sized communities, this thesis addresses the following questions:

- What have different communities, of varying sizes, done to provide local funding for bicycle and pedestrian capital projects?

- What types of local funding sources are being used for implementation?

- Is implementation success commensurate with the availability of funding?

Utilizing answers to these questions, this thesis will determine if the case study cities can offer a common funding factor used by these cities that can be generally applied. Where a common factor is not available, these case study cities will serve as examples of leaders in making their cities more safe and accessible for bicyclists and pedestrians. 


\section{Review of Existing Literature}

This literature review will cover traditional transportation design and its current impact on biking and walking. The review will then review existing movements that seek to redesign the existing transportation model to provide equity to all users. In looking at these movements, the literature review will also discuss ancillary benefits to these movements, such as improved safety and social capital. Lastly, this review will discuss the gaps in available sources of funding and alternative sources of funding.

\subsection{Traditional Transportation Design}

Traditional transportation design refers to a roadway design and maintenance methodology that focuses on separating motorist, pedestrian and bicycle uses for safety and convenience.

Traditional transportation design has its roots in the principles set up in the 1929 New York regional plan. This plan suggested that "streets should be adapted to the traffic load and kind of use they are destined to have; main internal streets should be 60 to 80 feet wide; secondary streets should be 30 to 60 feet wide (Southworth \& Ben-Joseph, 1995, p. 72)."

This traditional approach routed through traffic to arterial roadways, or higher capacity roadways, with higher speeds, that were available within and around most communities. In an attempt to provide a safe and calm environment within residential neighborhoods, traditional design limited through traffic by emphasizing curvilinear design and T-shaped streets, or streets with cul-desacs. This design approach reinforced a separation of land uses, and created a disconnected network of safe and low-speed roadways available to pedestrians and bicyclists. While this was not the key reason that generations of people in the mid to late $20^{\text {th }}$ century preferred driving over alternative modes of transportation, such as walking or bicycling, it has contributed to the lack of connected pedestrian and bicycle facilities across separately zoned uses. Additionally, the separation of land uses has contributed to a lack of trip attractors, due to lack of entertainment, dining and amenities within a reasonable walking or bicycling distance (Handy, Cao, \& Mokhtarian, 2005, p. 442; Saelens, Sallis, \& Frank, 2003, p. 83). 


\subsection{Safety}

Modern day curvilinear suburban street design was strongly encouraged by the National Institute of Transportation Engineers (ITE) in the mid-1950's. Engineering studies conducted over a five year period, $1951-1956$, showed $50 \%$ of residential grid pattern streets had a minimum of one accident during the five year study period. However, only $8.8 \%$ of residential streets with a "limited-access" street pattern had record of an accident during that same period. Additionally, streets with a T design were found to be $14 \%$ safer than those with four-leg intersections (Southworth \& Ben-Joseph, 1995, p. 77)." As a result of these findings, ITE published engineering guidelines in 1965 called the Recommended Practice for Subdivision Streets.

\subsection{Active Living}

Transportation Demand Management is defined as "a program designed to reduce demand for transportation through various means, such as the use of transit and of alternative work hours (Grant, D'Ignazio, \& McKeeman, 2013).” In the attempt to reduce demand for transportation, mitigate congestion, and reduce conflicts between motor vehicles and active modes of transportation, TDM measures are supportive of active living and sustainability (Gopalakrishna et al., 2012). "Planning processes that elevate TDM, namely transit and active transportation modes, to equals with road capacity solutions, will tend to support policy objectives related to livability (Gopalakrishna et al., 2012)."

\subsection{Alternative Transportation Movements}

Rising out of these separated land uses and roadways designed to accommodate motor vehicles at high capacity with minimal delay was a dangerous and unpleasant user experience for pedestrians and bicyclists. Not only did the distance between land uses make it inconvenient to run errands, travel to work or school, or go out to eat in any other mode than a motor vehicle, it also made it unsafe and uncommon (Congress for the New Urbanism, 2012; American Planning Association, 2010). Without proper facilities to travel on, pedestrians and bicyclists who chose to do more than stroll through neighborhood streets or ride in cul-de-sacs found themselves in dangerous situations where the roadway design made it known they didn't belong. 
Design and philosophical solutions to these challenges have their beginnings in the New Urbanism movement and Complete Streets. The New Urbanism movement, which began in 1993, advocates narrow street cross-sections supported by a compact and connected street network (Congress for the New Urbanism, 1999; Congress for the New Urbanism, 2012). In particular, "transit, pedestrian, and bicycle systems should maximize access and mobility throughout the region while reducing dependence on the automobile (Congress for the New Urbanism, 1999)." In 2003, America Bikes coined the term "complete streets" as in "a complete streets policy ensures that the entire right of way is routinely designed and operated to enable safe access for all users (American Planning Association, 2010)." A Complete Streets task force was formed to influence federal transportation policy (American Planning Association, 2010). By 2006, the task force had grown to include a number of nationally recognized transportation advocacy organizations and began to actively lobby states to create Complete Streets policy (American Planning Association, 2010).

As a result of this push toward street design with all users in mind, federal guidance from the Federal Highway Administration (FHWA) has come forward with formalized guidance on context sensitive solutions, which encourage the consideration of impacts on human and natural environments, and methods to design streets to avoid delay for all users (Federal Highway Administration, 2014; Transportation Research Board, 2010; Elias, 2011). These include the considerations of narrower roadway crossing distance for pedestrians, suggestions on altering roadway geometry to promote slower vehicle speeds, and the use of colored or buffered bikeways (Federal Highway Administration, 2014; Transportation Research Board, 2010).

\subsection{Transportation Financing}

Due to a lack of ability to keep pace with inflation, more fuel efficient vehicles, and a recent decline in vehicle miles traveled, funding from the federal level continues on a pattern of decline. “The 18.4-cent per gallon gas tax, not raised since 1993, provides insufficient funds to cover current transportation spending (Laing, 2013)." With less gas tax money available to pay for projects, and with constitutional restrictions in some states on the allocation of that money, local 
communities face stiffer competition when competing with one another for available state dollars to fund bicycle and streetscape infrastructure. At the local level, many communities find themselves in budget crises where they are planning street and road maintenance deferment to stretch their thin budgets and keep their existing community infrastructure held together by focusing their efforts on the direst situations. Even San Francisco, which has a sales tax measure, is frequently the focus of model city project funding, and is in the midst of a redevelopment boom, recently reported a $\$ 6.3$ billion gap in transportation funding needed over the next 15 years to modernize its transportation infrastructure and bring all deferred maintenance up to date (Coté, 2013). With crumbling public infrastructure, communities look to alternate sources to find the money necessary to fund the implementation of planned alternative infrastructure.

To understand what federal funding does cover, this section will review the current (as of 2013/2014) and prior years' federal funding. It will also review commonly used local option taxes. Since each state has unique legislation that defines how state funding can be allocated to bicycle, pedestrian and streetscape infrastructure, a review of existing and pending legislation will be covered in the data analysis and methodology section of this thesis as it specifically relates to each of the case study communities.

\subsection{Federal Funding}

The surface transportation system in the United States is funded by a transportation bill that distributes billions of dollars annually to states for capital improvements and maintenance for roads, transit, and bicycle and pedestrian facilities (De Zeeuw \& Flusche, 2011). The current bill that funds surface transportation is the Moving Ahead for Progress in the 21st Century Act (MAP21), which was signed into law by President Obama on July 6, 2012. MAP-21 supplies approximately $\$ 105$ billion in funding for surface transportation for fiscal year (FY) 2012 and FY 2013, and is the first long-term highway authorization enacted since 2005 (U.S. Department of Transportation, 2013). 
Federal funding is allocated to bicycle and pedestrian related projects through key federal programs: the Surface Transportation Program (STP), the Congestion Mitigation and Air Quality Program (CMAQ), the Transportation Alternatives Program (TAP), and the Highway Safety Improvement Program (HSIP). While each program has different stipulations, each also has the capacity to allow for funding of bicycle, pedestrian and streetscape projects. Federal funds are distributed regionally through Metropolitan Planning Organizations.

STP funding can be used by states and localities on projects that preserve and improve the conditions and performance for pedestrian and bicycle infrastructure. $50 \%$ of the funds are required to be distributed to areas based on population: urbanized areas with population greater than 200,000 , areas with population greater than 5,000 but no more than 200,000 , areas with population of 5,000 or less. The remaining $50 \%$ can be used in any area of the state ("Surface Transportation Program (STP)," 2013). Eligible projects can include: bicycle transportation and pedestrian walkways and ADA sidewalk modification, transportation alternatives, and recreational trails projects (“Surface Transportation Program (STP)," 2013).

CMAQ was initially created by the Intermodal Surface Transportation Efficiency Act (ISTEA) of 1991, and has been reauthorized in all subsequent surface transportation acts, including MAP-21 (Federal Highway Administration, 2013). Previous surface transportation act "funding apportionments for each state were calculated based on a formula for weighted populations" in areas that have excessive ozone and carbon monoxide (CO), and are considered areas that either do not meet clean air standards (nonattainment) or have not met clean air standards in the past (maintenance areas) under the Clean Air Act (Federal Highway Administration, 2013). Under MAP-21, funding apportionments are no longer calculated based on a formula. However states are expected to utilize the equivalent of $25 \%$ of their funding to target fine particle particulate matter (PM2.5) reductions in their nonattainment or maintenance areas (Federal Highway Administration, 2013). Additionally, FY 2013 and FY 2014 funding is based on FY 2009 funding, which utilized the formula for weighted populations (Federal Highway Administration, 2013). As a result, each state continues to receive minimum funding allocations based on those FY 2009 
apportionments (Federal Highway Administration, 2013). With MAP-21, states also have increased spending flexibility. With the exception of the $25 \%$ set aside for PM2.5 nonattainment or maintenance, a state has the flexibility to spend the CMAQ funding on any project that meets basic criteria. CMAQ apportionments can be used to fund "new or expanded transportation projects that reduce emissions" (Federal Highway Administration, 2013). As a result, this funding program allows flexibility in the types of capital projects to be funded. In addition to other types of projects, CMAQ can fund travel demand management strategies, traffic flow/management improvements, and bicycle and pedestrian facilities (Federal Highway Administration, 2013; Sacramento County Department of Transportation, 2013).

TAP funding is new as of FY 2013, and consolidates previous funding from pre-MAP-21 programs including Transportation Enhancements, Recreational Trails, Safe Routes to School, and several other discretionary programs, wrapping them into a single funding source. It allocates $2 \%$ of the total amount authorized from the Highway Account of the Highway Trust Fund for Federal-aid highways each fiscal year (Federal Highway Administration, 2013). A state may transfer up to $50 \%$ of TAP funds for use statewide to the National Highway Performance Program (NHPP), STP, HSIP, CMAQ, and/or Metropolitan Planning. Projects or activities can qualify for TAP funding if they are related to surface transportation and a described transportation alternative; recreational trail program; safe routes to school program; or the plan, design or construction of roadways in the right-of-way of former interstate system routes or divided highways. As described by Title 23, United States Code, 2012, these types of projects or activities can involve the following:

- Construction, planning, and design of on-road and off-road trail facilities for pedestrians, bicyclists, and other non-motorized forms of transportation.

- Construction, planning, and design of infrastructure-related projects and systems that will provide safe routes for non-drivers, including children, older adults, and individuals with disabilities to access daily needs. 
- Conversion and use of abandoned railroad corridors for trails for pedestrians, bicyclists, or other non-motorized transportation users.

HSIP replaced STP Safety in FY 2006 and can be used for non-infrastructure safety improvement programs. This funding can be used to improve bicycle and pedestrian facilities when they are tied to a candidate project that intends to correct or improve a hazardous road location or feature, or address a highway safety problem. The candidate project must provide documentation in the "form of crash experience, crash potential, crash rate or other data-supported means" (Federal Highway Administration, 2013).

Stand-alone funding sources from previous surface transportation bills that have remaining money available, such as Surface Transportation Program set-aside for Transportation Enhancement Activities (STP TE) or Safe Routes to School (SRTS), continue to be distributed until the funding is exhausted (Federal Highway Administration, 2013).

\subsection{Alternative Funding Sources}

Different cities have found ways to fund their alternative infrastructure though local option taxes, developer requirements, crowdsourcing, parklets policies and fees, and cordon pricing.

\subsubsection{Local Option Taxes}

Local option taxes are typically voter-approved, single-county sales taxes that are tied to legally binding expenditure plans (Goldman \& Wachs, 2003; Goldman, 2005). In many states, they increasingly dominate transportation planning and finance (Goldman \& Wachs, 2003; Goldman, 2005). They have the ability to create opportunities for innovation by empowering interest groups and policy entrepreneurs to play more direct roles in transportation decision-making (Goldman, Corbett, \& Wachs, 2001).

\subsubsection{Developer Requirements and Parking Revenues}

As a part of its Great Streets master plan, Austin, TX has developed streetscape design standards for its downtown core (City of Austin, 2012). Developers are required to implement these streetscape standards at their own cost, but can qualify for partial reimbursement (City of 
Austin, 2014). City of Austin reimbursement funds are from a $30 \%$ set aside of parking revenues collected in the Great Streets program boundary area (City of Austin, 2014).

\subsubsection{Crowdsourcing}

The City of Memphis has used only private funding to implement a $\$ 4.5$ million two-way protected bike lane project called The Hampline. The City was the first in the country to use crowdsourcing to fund this type of project (Andersen, 2013). The neighborhood crowdsourcing site loby.org was used to raise the final $\$ 75,000$ of the project costs, and as of November 26,2014 , all funds have been raised (Overtonbroad, n.d.).

Inspired by the Memphis example, business leaders in Denver, CO, the Downtown Denver Partnership, launched an Arapahoe Street protected bike lane funding campaign on October 28, 2014 through loby.org (Andersen, 2014). As of November 26, 2014, the campaign has raised $\$ 14,876$ of the total requested $\$ 36,000$ to pay for planning and design of the protected bike lane (Arapahoe Street protected bike lane, 2014).

\subsubsection{Parklets}

Through the parklet model, cities are able to allow residents and business owners to utilize parking spaces and sidewalk space to create appealing and creative streetscape features. San Francisco has actually turned this into a revenue generation model as well. The City provides design, engineering, materials and installation guidelines, and usage and maintenance guidelines (City of San Francisco, 2013. The applicant has to submit a preliminary proposal for review and public comment (City of San Francisco, 2013. If accepted, the applicant then develops a detailed project proposal which includes a budget, and final construction plans (City of San Francisco, 2013. If these plans meet the City requirements, a permit is issued (City of San Francisco, 2013). In the City of San Francisco, initial fees start at $\$ 1,632.50$ and increase where there is a need to remove parking meters or take up more parking spaces (City of San Francisco, 2013). Annual permit renewals are approximately $\$ 221$ (City of San Francisco, 2013). 
Parklets have become very popular. Related policies have been developed in at least the following cities (Luskin School of Public Affairs, 2012):

- New York City, NY

- Philadelphia, PA

- Los Angeles, CA

- Long Beach, CA

- Montreal

- Vancouver

- Oakland, CA

- San Francisco, CA

\subsubsection{Cordon Pricing}

International cities such as London, Singapore, Stockholm, and Milan have had success using cordon pricing systems to reduce vehicle congestion related delay in their financial and urban centers (May, Liu, Shepherd, \& Sumalee, 2002; Liu, Wang, Qu, \& Shiwakoti, 2014). The City of London began charging private vehicles this type of fee to enter Central London on weekdays as of 2003 (Litman, 2006). In London, this pricing strategy has been combined with improvements to transit and improvements to safety and access for bicyclists and pedestrians. The result of this strategy is reduced congestion related delays in central city roadways during peak hours and a safer roadway environment for non-motorized travelers (Komanoff, 2013). London has also had success using fees collected from their cordon pricing system to pay for enhanced bicycle and pedestrian infrastructure. As of $2006 / 2007$, approximately 3\% of net revenues ( $\$ 4$ million of $\$ 137$ million in revenues) were spent on support for new pedestrian crossings and cycling initiatives (Transport for London, 2008). 


\section{Methodology and Data Analysis Process}

\subsection{Proposition and Secondary Research Questions}

In seeking to understand if the most widely used approaches to funding bicycle and pedestrian infrastructure in varied communities across the United States can be gleaned from this study, this thesis also discusses what the top cities of varying sizes have done to fund bicycle and pedestrian projects.

This thesis also seeks to address these three secondary concerns: types of funding sources being utilized for implementation; whether implementation success is commensurate with the availability of funding; and the combinations of funding, policy framework and implementation strategies that are most common for these communities.

\subsection{Approach}

This thesis will use a convergent parallel mixed-method approach to evaluate the way communities are funding their bicycle, pedestrian, and streetscape projects. Mixed-method approaches are valued for their comprehensive coverage of a problem, because they can "free researchers from becoming the prisoner of a particular method of technique and from simply presenting findings derived through different methods alongside each other but discussing them separately (Molenaar, Lerner, \& Newell, 2013)." Using this method, quantitative data are gathered from qualified sources. As data is analyzed, and trends are identified, qualitative research in the form of an in-depth review of government documents will be conducted to confirm or redirect data analysis.

\subsection{Unit of Analysis}

This thesis seeks to understand how communities across the U.S. are financing bicycle and pedestrian infrastructure through the analysis of local funding sources from an initial pool of thirtysix U.S. communities. These are thirty-six communities that have become standard bearers for bicycle and walking activity and legislation. 


\subsection{Data Sources}

The thirty-six Communities analyzed for this thesis were derived from ranked communities that were listed both as a "Walk Friendly Community" (WFC) by the Pedestrian and Bicycle Information Center (PBIC), and as a "Bicycle Friendly Community" (BFC) by the League of American Bicyclists (2012/2013). The PBIC is funded by the Federal Highway Administration and housed within the University of North Carolina Safety Research Center. To become ranked as a WFC by the PBIC, a community must show a commitment to improving walkability and pedestrian safety through comprehensive programs, plans and policies (Pedestrian and Bicycle Information Center). The League of American Bicyclists is a national bicycle advocacy organization that seeks to provide leadership, "define standards and share best practices to engage diverse communities" (League of American Bicyclists). To become ranked as a BFC by the American League of Bicyclists, a community must be "one that welcomes cyclists with trails, bike lanes, share the road campaigns, organized rides, Bike to Work Day events and so much more" (League of American Bicyclists). They are evaluated based on how their "community encourages people to bike for transportation and recreation through the five E's: engineering, education, encouragement, enforcement, and evaluation (League of American Bicyclists).

This cross-tabulation method generated a diverse set of Communities that meet the criteria required to be Bicycle Friendly Community and to be a Pedestrian Friendly Community. They represent 24 states, have populations that range from 1,351 in Grand Marais, MN to 1,526,006 in Philadelphia, PA, and have varied weather, political climates, racial make-up, and population densities.

Primary data for these Communities were collected from The League of American Bicyclists, Smart Growth America, the Pedestrian and Bicycle Information Center, the United States Census, and the Federal Highway Administration. Additional primary data was collected for case study cities from the most recently approved budget; capital improvement programs (CIP); financial plans; Comprehensive or General Plans; pedestrian, bicycle or streetscape master plans; and redevelopment and tax increment financing (TIF) district plans. City staff was not 
directly consulted. Scholarly articles, books, press articles, websites, theses or dissertations and other case studies were utilized as secondary data sources. 


\section{Case study methodology}

Analysis of the list of thirty-six initial cities revealed trends that helped to identify cities that stood out as practice leaders in the implementation of bicycle and pedestrian infrastructure. These trends informed the methodology for choosing case study cities:

- Seventeen of thirty-six communities had a bicycle planning document.

- Nineteen of thirty-six communities had bicycle and/or pedestrian planning language incorporated into their general plan or comprehensive plan.

- Twenty of thirty-six communities had a local Complete Streets Policy.

- Ten of thirty-six communities had more than $90 \%$ of elementary schools offering bike education, and sixteen of thirty-six had more than $51 \%$ of elementary schools offering bike education.

- Eleven of thirty-six communities had more than $90 \%$ of middle schools offering bike education.

- Thirteen of thirty-six communities had $1-25 \%$ of arterial streets with dedicated bicycle lanes, and ten of thirty-six had $26-50 \%$ of arterial streets with dedicated bicycle lanes.

Out of an initial thirty-six cities, eleven cities were selected for in-depth analysis of methods employed to implement pedestrian, bicycle and streetscape infrastructure. These cities were evaluated based on the trends listed above, which indicated their level of commitment to facilities, financing, and planning. These eleven cities stood out for their high number of implemented policy, budget measures, existing modal share, Safe Routes to School Programming, and percentage of arterial streets with bicycle lanes.

The process of selection began with dividing the thirty-six cities into four city population size groups:

- $1,000-49,999$

- $\quad 50,000-99,999$

- $100,000-299,999$ 
- Greater than 300,000

This size grouping was modeled after the Research Brief on America's Cities (Hoene \& Pagano, 2013). Within each population size grouping, the cities were given a point for having each of the possible twelve criteria as shown in Table 1.

Table 1 - Case Study Selection Criteria

\begin{tabular}{|l|l|}
\hline City Data & Receive one point \\
\hline Bicycle Master plan & $Y$ \\
\hline Pedestrian Master plan & $Y$ \\
\hline Pedestrian and Bicycle Plan & $Y$ \\
\hline Pedestrian \& Bike Needs addressed in Comprehensive Plans & $\mathrm{Y}$ \\
\hline Complete Streets Plan (Local) & $\mathrm{Y}$ \\
\hline Plan Funding Component & $\mathrm{Y}$ \\
\hline$\%$ of Commuter Mode Share - Bicycle & $>/=5 \%$ \\
\hline$\%$ Commuter Modal Share - Walking & $>1=5 \%$ \\
\hline$\%$ Commuter Modal Share - Transit & $>1=5 \%$ \\
\hline$\%$ of Elementary Schools offering Bike Education & $>50 \%$ \\
\hline$\%$ of Middle Schools offering Bike Education & $>50 \%$ \\
\hline$\%$ of Arterial Streets with Bike Lanes & $>50 \%$ \\
\hline
\end{tabular}

The resulting points were totaled to create a score for each city. The cities with the highest score in each population size category were selected as the focus of the case studies section of this paper.

For the population size category $1,000-49,999$, the City and Borough of Juneau scored a total of eight out of twelve points due its strong balance of policy and funding documents, commuter mode share, and provision of bike education. To more fully understand this population size category, the study also included case studies for the cities with the second highest scores; Charlottesville, VA, and Shorewood, WI. For the population size category 50,000 - 99,999, the City of Santa Barbara scored a total of ten out of twelve points due to a high number of policy documents. The second highest scoring city in that category; Santa Monica, CA, was also included in the case studies section. The eleven cities selected as the focus of the case studies were as shown in Figure 1 and in the list below. 
Figure 1 - Case Study Cities

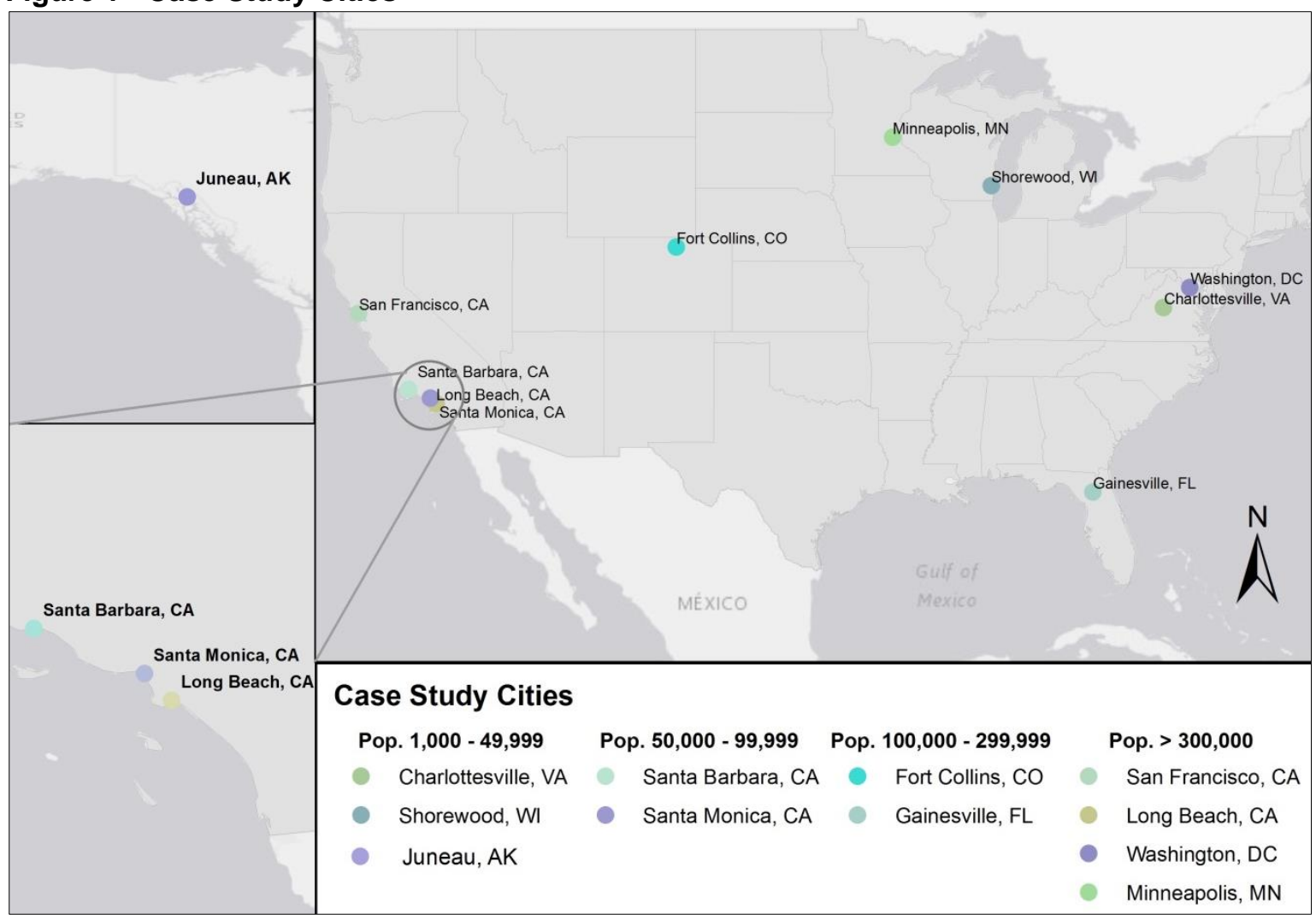

- Juneau, Alaska (Population Size: 1,000 - 49,999)

- Charlottesville, Virginia (Population Size: 1,000 - 49,999)

- Shorewood, Wisconsin (Population Size: 1,000 - 49,999)

- Santa Barbara, California (Population Size: 50,000 - 99,999)

- Santa Monica, California (Population Size: 50,000 - 99,999)

- Fort Collins, Colorado (Population Size: 100,000 - 299,999)

- Gainesville, Florida (Population Size: 100,000 - 299,999)

- Long Beach, California (Population Size: Greater than 300,000)

- Minneapolis, Minnesota (Population Size: Greater than 300,000)

- San Francisco, California (Population Size: Greater than 300,000)

- Washington, District of Columbia (Population Size: Greater than 300,000)

To understand the funding mechanisms used to implement bicycle and pedestrian capital projects, this study examined available public documents from each of the case study cities.

While all communities studied were unique in their approach to financing bicycle and pedestrian infrastructure, they all lacked sufficient federal, state and traditional local funds necessary to complete, or even schedule the implementation, of these capital projects. The following case 
studies illustrate creative local funding mechanisms utilized to achieve these goals. Many of these case studies also discuss continued shortfalls and possible creative solutions that may be addressed in their communities during future policy updates. 


\section{Case Studies}

5.1. Cities with Population Size: 1,000 - 49,999

Table 2 - City Scoring Matrix for size 1,000 - 49,999

\begin{tabular}{|c|c|c|c|c|c|c|c|c|c|c|c|c|c|c|}
\hline \multicolumn{15}{|c|}{ Population size 1,000 - 49,999 } \\
\hline \multicolumn{2}{|c|}{ Green Criteria (1 pt.) } & $\mathbf{Y}$ & $\mathbf{Y}$ & $\mathbf{Y}$ & $\mathbf{Y}$ & $\mathbf{Y}$ & $Y$ & $>/=5 \%$ & $>/=5 \%$ & $>/=5 \%$ & $>50 \%$ & $>50 \%$ & $>50 \%$ & \\
\hline & & \multicolumn{6}{|c|}{ Master Planning (policy \& funding) } & \multicolumn{3}{|c|}{ Commuter Mode Share } & \multicolumn{2}{|c|}{$\begin{array}{l}\text { Bicycle Education } \\
\text { Provision }\end{array}$} & Infrastructure & \\
\hline CitySTATE & $\begin{array}{l}\text { Pop. } \\
\text { size }\end{array}$ & Bike & Pedestrian & $\begin{array}{l}\text { Pedestrian } \\
\text { \& Bike }\end{array}$ & $\begin{array}{l}\text { Ped \& Bike } \\
\text { needs } \\
\text { addressed } \\
\text { in Plans }\end{array}$ & $\begin{array}{l}\text { Complete } \\
\text { Streets } \\
\text { Plan } \\
\text { (Local) }\end{array}$ & $\begin{array}{l}\text { Funding } \\
\text { Component }\end{array}$ & $\begin{array}{l}\% \\
\text { bicycle }\end{array}$ & $\begin{array}{l}\% \\
\text { walking }\end{array}$ & $\begin{array}{l}\% \\
\text { transit }\end{array}$ & $\begin{array}{l}\% \\
\text { elementary } \\
\text { schools }\end{array}$ & $\begin{array}{l}\% \\
\text { middle } \\
\text { schools }\end{array}$ & $\begin{array}{l}\% \text { of arterial } \\
\text { streets with } \\
\text { bike lanes }\end{array}$ & $\begin{array}{l}\text { Total } \\
\text { Green }\end{array}$ \\
\hline JuneauAK & 31,275 & $\mathrm{~N}$ & $\mathrm{~N}$ & $\mathbf{Y}$ & $\mathbf{Y}$ & $\mathbf{Y}$ & $\mathbf{Y}$ & $2 \%$ & $9 \%$ & $5 \%$ & $>90 \%$ & $>90 \%$ & $26-50 \%$ & 8 \\
\hline CharlottesvilleVA & 43,475 & $\mathrm{~N}$ & $\mathrm{~N}$ & $\mathbf{Y}$ & $\mathrm{N}$ & $\mathbf{Y}$ & $\mathbf{Y}$ & $3 \%$ & $12 \%$ & $8 \%$ & $>90 \%$ & $>90 \%$ & $26-50 \%$ & 7 \\
\hline ShorewoodWI & 13,162 & $\mathbf{Y}$ & $\mathrm{N}$ & $\mathrm{N}$ & $\mathbf{Y}$ & $\mathrm{N}$ & $\mathrm{N}$ & $3 \%$ & $8 \%$ & $5 \%$ & $>90 \%$ & $>90 \%$ & $100 \%$ & 7 \\
\hline DavidsonNC & 10,944 & $Y$ & $\mathbf{Y}$ & N & $\mathrm{N}$ & $\mathbf{Y}$ & $Y$ & $1 \%$ & $8 \%$ & $5 \%$ & $0 \%$ & $0 \%$ & $26-50 \%$ & 6 \\
\hline DecaturGA & 19,335 & $\mathrm{~N}$ & $\mathrm{~N}$ & $\mathrm{~N}$ & Y & $\mathbf{Y}$ & $\mathbf{Y}$ & $1 \%$ & $4 \%$ & $7 \%$ & $>90 \%$ & $>90 \%$ & $1-25 \%$ & 6 \\
\hline ConcordNH & 42,695 & $\mathbf{Y}$ & $\mathrm{N}$ & N & $\mathrm{N}$ & $\mathbf{Y}$ & $Y$ & $1 \%$ & $4 \%$ & $1 \%$ & $26-50 \%$ & $76-99 \%$ & $51-75 \%$ & 5 \\
\hline Coeur d'AleneID & 44,137 & $\mathbf{Y}$ & $\mathrm{N}$ & $\mathrm{N}$ & $Y$ & $\mathbf{Y}$ & N & $1 \%$ & $3 \%$ & $0 \%$ & $51-75 \%$ & $26-50 \%$ & $26-50 \%$ & 4 \\
\hline Grand MaraisMN & 1,351 & N & $\mathrm{N}$ & N & $\mathrm{N}$ & $\mathrm{N}$ & N & $0 \%$ & $24 \%$ & $0 \%$ & $>90 \%$ & $>90 \%$ & $100 \%$ & 4 \\
\hline Grand RapidsMN & 10,869 & $\mathrm{~N}$ & $\mathrm{~N}$ & N & Y & $\mathbf{Y}$ & N & $2 \%$ & $4 \%$ & $3 \%$ & $>90 \%$ & $>90 \%$ & $26-50 \%$ & 4 \\
\hline LincolnNE & 36,288 & N & $\mathrm{N}$ & $\mathrm{N}$ & $Y$ & $\mathbf{Y}$ & $\mathbf{Y}$ & $1 \%$ & $3 \%$ & $1 \%$ & $51-75 \%$ & $26-50 \%$ & $1-25 \%$ & 4 \\
\hline OxfordMS & 18,916 & N & $\mathrm{N}$ & $\mathbf{Y}$ & $Y$ & $\mathbf{Y}$ & N & $1 \%$ & $2 \%$ & $0 \%$ & $26-50 \%$ & $>90 \%$ & $1-25 \%$ & 4 \\
\hline NorthamptonMA & 28,549 & $\mathrm{~N}$ & $\mathrm{~N}$ & $\mathrm{~N}$ & $\mathbf{Y}$ & $\mathbf{Y}$ & $\mathrm{N}$ & $3 \%$ & $11 \%$ & $3 \%$ & $1-25 \%$ & $0 \%$ & $26-50 \%$ & 3 \\
\hline
\end{tabular}




\subsubsection{Charlottesville, Virginia}

Key Local Funding Sources: General Fund, Bond Issues

For cities with the population size between 1,000 and 49,999, Charlottesville, Virginia was one of three cities to receive seven points out of a total possible twelve points (see Table 3 below). For its size, Charlottesville stood out for having important policy and funding in place, as well as a higher than average modal share for walking and transit, and a higher than average percentage of Safe Routes to School programming implemented. Charlottesville is ranked by the League of American Bicyclists as a Silver Community, and it is considered a Gold Level Walk Friendly Community by the Pedestrian and Bicycle Info Center.

Table 3 - Charlottesville, VA Score

\begin{tabular}{|l|l|}
\hline City Data & Receive one point \\
\hline Bicycle Master plan & $\mathrm{N}$ \\
\hline Pedestrian Master plan & $\mathrm{N}$ \\
\hline Pedestrian and Bicycle Plan & $\mathrm{Y}$ \\
\hline $\begin{array}{l}\text { Pedestrian/Bicycle Planning Language in } \\
\text { Comprehensive Plan/Transportation Plan }\end{array}$ & $\mathrm{N}$ \\
\hline Complete Streets Plan (Local) & $\mathrm{Y}$ \\
\hline Plan Funding Component & $\mathrm{Y}$ \\
\hline$\%$ of Commuter Mode Share - Bicycle & $</=5 \%$ \\
\hline$\%$ Commuter Modal Share - Walking & $>/=5 \%$ \\
\hline$\%$ Commuter Modal Share - Transit & $>/=5 \%$ \\
\hline$\%$ of Elementary Schools offering Bike Education & $>50 \%$ \\
\hline$\%$ of Middle Schools offering Bike Education & $>50 \%$ \\
\hline$\%$ of Arterial Streets with Bike Lanes & $<50 \%$ \\
\hline Total Score & 7 points \\
\hline
\end{tabular}

\subsubsection{Population and Demographics}

Charlottesville, Virginia, has a population of 43,475 and covers a total area of 10.2 acres, with a population density of 4,246 and a median age of 28 years. The racial demographics are $69.1 \%$ White, 19.4\% Black, 0.3\% American Indian, and 6.4\% Asian (U.S. Census, 2010). Of the total population, $5.1 \%$ classify themselves as Hispanic or Latino (U.S. Census, 2010). 


\subsubsection{Policy Implementation}

The Charlottesville City Council has a stated vision and commitment to a connected community, which is "part of a comprehensive, regional transportation system that enables citizens of all ages and incomes to easily navigate [the] community. An efficient and convenient transit system supports mixed use development along [the] commercial corridors, while bike and pedestrian trail systems, sidewalks, and crosswalks enhance [the] residential neighborhoods. A regional network of connector roads helps to ensure that residential neighborhood streets remain safe and are not overburdened with cut-through traffic (City of Charlottesville, 2013)." Their comprehensive plan received an extensive update in 2013 , and incorporates an emphasis on a transportation system that supports a safe, livable community through sustainable land use patterns and a multimodal transportation network (City of Charlottesville, 2013). The plan also identifies the need to extend their sidewalk network across city-county boundaries and complete their bicycle network (City of Charlottesville, 2013).

The comprehensive plan discussed thirteen small area plans. These were designed for "short term, intensive public planning process... which will contain implementation elements to guide the City in accomplishing the recommended changes of each area plan" (City of Charlottesville, 2013). The most recent small area plan developed by the city is the Strategic Investment Area (SIA) Plan for the downtown core. The SIA contains public space standards and guidelines to facilitate walkability and implementation of the bicycle and pedestrian plan (City of Charlottesville, VA, 2013). The document provides a funding and implementation framework, and recommends "partnerships between the Housing Authority and Private Developers or with the City are key for funding and to promote a unified vision" (City of Charlottesville, VA, 2013). Some of the lessons learned from the small area plans have been incorporated in the latest comprehensive plan update.

The City of Charlottesville adopted a Bicycle and Pedestrian Master plan in 2003, and it is currently in the process of updating this plan (City of Charlottesville, 2003). The updates will include a focus on stakeholder approval, and a use of demonstration projects for pedestrian and 
bicycle facilities to prove their efficacy and value. Additionally, the City is in the process of updating their Complete Streets guidelines, which are motivated by a February 2014 City Council directive that "reaffirmed its commitment to creating complete streets for all users and adopted a resolution to consider the context surrounding the streets as part of any future street design process. As part of the resolution, Council directed staff to undertake a planning process that will reflect the understanding that streets serve a multitude of transportation, economic, social, recreational and ecological needs that must be considered when deciding on the most appropriate design (City of Charlottesville, 2014)." The target year for completing this plan is 2015.

\subsubsection{General Fund}

The City's general fund is "usually referred to as the operating fund and is used to finance the day-to-day operations of the City. It is the largest part of the City's total financial operation. Revenues for this fund are obtained from taxes, licenses and permits, intergovernmental revenue, charges for services, fines, interest, and City/County Revenue Sharing funds (City of Charlottesville, 2013)." The general fund allocates $3 \%$ annually to the Capital Improvement Program Fund, but does not otherwise earmark funding towards pedestrian and bicycle projects.

\subsubsection{Capital Improvement Program}

The City Council adopted fiscal year (FY) 2014 budget allocates $40 \%$ of the capital improvement program funds towards sidewalk installation and repair, streetscape projects, and bicycle infrastructure (City of Charlottesville, 2013). Per the budget, "the Capital Improvement Program Fund is used to account for all financial resources that are needed in the acquisition or construction of capital assets. Revenues for this fund are obtained from bond issues, a transfer from the General fund (City/County Revenue Sharing), a contribution from the City Schools for their small capital projects program, and contributions from Albemarle County for shared projects" (City of Charlottesville, 2013). As shown in Table 4, the City has committed consistent and, in some cases, increasing funding over the 2014 budget year and next four projected years. Neighborhood improvements are also facilitated through a Neighborhood CIP Funds project. Per 
the 2014 CIP, $\$ 47,500$ has been allocated towards capital project needs "solicited by neighborhoods or determined to be needed by City Council" (City of Charlottesville, 2013).

Table 4 - City of Charlottesville, VA Capital Improvement Funds, FY 2014 Budget Cycle Bondable Projects - Transportation and Access

\begin{tabular}{|c|c|c|c|c|c|c|c|}
\hline Project & Adopted FY14 & Projected FY15 $\square$ & Projected FY16 & Projected FY17 & Projected FY18 & 5 Year Total $\mathrm{r}$ & YOY \% increase \\
\hline New Sidewalks & 285,000 & 285,000 & 285,000 & 285,000 & 285,000 & $1,425,000$ & 0 \\
\hline West Main Streetscape & - & 750,000 & 750,000 & 750,000 & - & 225,000 & 0 \\
\hline Martha Jefferson Neighborhood Streetscaping & 50,000 & 300,000 & - & - & - & 350,000 & 0 \\
\hline
\end{tabular}

Martha Jefferson Neighborhood Streetscaping

Non-Bondable Projects - Transportation and Access

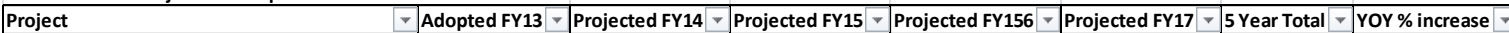

\begin{tabular}{|c|c|c|c|c|c|c|c|}
\hline Project & Adopted FY13 - & Projected FY14 - & Projected FY15 - & Projected FY156 & Projected FY17 ${ }^{-}$ & 5 Year Total $\vee$ & YOY \% increase \\
\hline Sidewalk Repair & 203,587 & 205,623 & 207,679 & 209,756 & 211,854 & $1,038,499$ & 19 \\
\hline Citywide ADA Improvments - Sidewalks and Cur & 95,000 & 95,000 & 95,000 & 95,000 & 95,000 & 475,000 & \\
\hline
\end{tabular}

\begin{tabular}{|c|c|c|}
\hline & & \\
\hline Bicycle Infrastructure & 200,000 & 200000 \\
\hline
\end{tabular}

Note: Adapted from City of Charlottesville, 2013

\subsubsection{Future Funding}

The Pedestrian and Bicycle Master plan identifies public/private partnerships as a funding source to complete identified projects, but the City does not have available documents online which outline the implementation of this type of funding. The small area plans also emphasize public/private partnerships as key funding resources.

\subsubsection{Juneau, Alaska}

Key Local Funding Sources: Sales Tax Measure, Marine Passenger Fee, Developer In-Lieu Fees For communities with the population size between 1,000 and 49,999, Juneau, Alaska was one of three communities to receive seven points out of a total possible twelve points (see Table 5 below). The City and Borough of Juneau stood out for having important policy and funding in place, as well as a higher than average modal share for walking and transit, and a higher than average percentage of Safe Routes to School programming implemented. Juneau lags in the percentage of arterial streets with bike lanes and in its percentage of bicycle commuters. The City and Borough of Juneau is ranked by the League of American Bicyclists as a Bronze Community, and it is considered an Honorable Mention Walk Friendly Community by the Pedestrian and Bicycle Info Center. 
Table 5 - Juneau, AK Score

\begin{tabular}{|l|l|}
\hline City Data & Receive one point if: \\
\hline Bicycle Master plan & $\mathrm{N}$ \\
\hline Pedestrian Master plan & $\mathrm{N}$ \\
\hline Pedestrian and Bicycle Plan & $\mathrm{Y}$ \\
\hline $\begin{array}{l}\text { Pedestrian/Bicycle Planning Language in } \\
\text { Comprehensive Plan/Transportation Plan }\end{array}$ & $\mathrm{Y}$ \\
\hline Complete Streets Plan (Local) & $\mathrm{Y}$ \\
\hline Plan Funding Component & $\mathrm{Y}$ \\
\hline$\%$ of Commuter Mode Share - Bicycle & $</=5 \%$ \\
\hline$\%$ Commuter Modal Share - Walking & $>/=5 \%$ \\
\hline$\%$ Commuter Modal Share - Transit & $>/=5 \%$ \\
\hline$\%$ of Elementary Schools offering Bike Education & $>50 \%$ \\
\hline$\%$ of Middle Schools offering Bike Education & $>50 \%$ \\
\hline$\%$ of Arterial Streets with Bike Lanes & $<50 \%$ \\
\hline Total Score & $\mathbf{8}$ points \\
\hline
\end{tabular}

\subsubsection{Population and Demographics}

Juneau, Alaska, has a population of 31,275 and covers a total area of $3,248.0$ acres, with a population density of 9 and a median age of 38 years. The racial demographics are $69.7 \%$ White, 0.9\% Black, 11.8\% American Indian, 6.1\% Asian, and 0.7\% Native Hawaiian (U.S. Census, 2010). Of the total population, $5.1 \%$ classify themselves as Hispanic or Latino (U.S. Census, 2010).

\subsubsection{Policy Implementation}

The City and Borough of Juneau adopted a Non-Motorized Transportation Plan (NMTP) on November 2, 2009. This plan updated the 1997 NMTP and incorporates Complete Streets policy and design fundamentals (City and Borough of Juneau, 2009). Policy 3 of the NMTP states in part that "Project managers will use a context sensitive approach in the design of City projects to achieve a Complete Streets network" (City and Borough of Juneau, 2009). The plan updated the 1997 plan, and provides a straight-forward implementation plan that identifies top project priorities which address bike route and sidewalk infrastructure connectivity and safety. The Non-Motorized Transportation Plan identifies prioritization criteria, giving highest scores to proximity to community destination, maximum potential residential density, annual daily traffic count, and 
proximity to accidents (City and Borough of Juneau, 2009). It also defines policies designed to streamline infrastructure implementation, such as (City and Borough of Juneau, 2009):

- Ready to fund - defining concept plans, budgets and project scopes for prioritized projects to put the City in the position of being able to take advantage of funding as it becomes available.

- State Projects - Work with state DOT to exercise input early in the state project design process to generate mutually beneficial expectations and timing of road project reviews.

- Municipal Projects - Improve timing of inter-agency review to reduce extensive redesign and delay.

- Private Sector Development - Review design standards to provide ways to make subdivision design more context sensitive.

- Transportation Planning - Complete motorized and non-motorized planning, design and construction together.

- Cross Juneau Bikeway - Complete missing segments in cross Juneau bikeway to provide a safe and direct route across town and between neighborhoods, which will encourage non-motorized commuting.

\subsubsection{Funding}

A thorough review of Juneau's general fund, capital improvement program, and the Alaska State Department of Transportation's State Transportation Improvement Program (STIP), revealed that major development projects were reliant on a mixture of federal, state and local funding, as shown in Table 6 below.

Table 6 - Juneau Programming Projects Reviewed, FY 2012 - 2015

\begin{tabular}{|l|l|r|}
\hline Projects Reviewed & \multicolumn{1}{|l|}{ Amount } & Percentage \\
\hline State Funds Scheduled & $\$ 19,404,840$ & $41.96 \%$ \\
\hline Federal Funds Scheduled & $\$ 11,922,917$ & $25.78 \%$ \\
\hline State Funds Unscheduled & $\$ 12,430,000$ & $26.87 \%$ \\
\hline CIP - Areawide Sales Tax & $\$ 1,450,000$ & $3.14 \%$ \\
\hline Private & $\$ 93,750$ & $0.20 \%$ \\
\hline CIP - Marine Passenger Fee & $\$ 950,000$ & $2.05 \%$ \\
\hline
\end{tabular}

Note: Adapted from State of Alaska Department of Transportation \& Public Facilities, 2014

Private funding sources were suggested in the policy implementation documents reviewed, but not detailed in the funding programming documents. Additionally, the Juneau Non-Motorized Transportation Plan provided an informational listing of possible funding sources for non- 
motorized facilities, which included local to federal programs and grants, and provided eligibility guidelines, application timing and contact information, but did not directly tie any project to a committed source (City and Borough of Juneau, 2009).

\subsubsection{General Fund}

The general fund is used to account for all the financial operations of the City and Borough not required to be accounted for in any other fund. (City and Borough of Juneau, 2013). The general fund allocates $4 \%$ of the $5 \%$ sales tax temporarily towards capital improvement projects. These allocations are based on voter approved initiatives. $1 \%$ of that sales tax levy (approximately $\$ 8.0$ million), through June 30,2017 , is allocated towards funding "repair and construction of streets, sidewalks, retaining walls, drainages, and stairway capital projects" (City and Borough of Juneau, 2013).

\subsubsection{Capital Improvement Program (CIP)}

The Downtown Waterfront 2025 Concept Plan also identifies multiple redevelopment projects that include development of new or expanded sidewalks and streetscape features. These streetscape projects are slated to be funded with a combination of City and Borough, Port Revenues, and private funding (City and Borough of Juneau, 2004). As part of this plan, a pedestrian boardwalk, or seawalk, will be constructed to provide a pedestrian connection along the entire downtown waterfront area. This also incorporates the waterfront area used by cruise ship docking and passenger facilities.

Identified in the $2012-2015$ CIP, this seawalk is partially funded by a Marine Passenger Fee. This is a fee imposed on each marine passenger to address costs to the City and Borough for services and infrastructure usage by cruise ship passengers (City and Borough of Juneau, Alaska, 2000).

The 2012-2015 CIP also allocates funding to sidewalk, streetscape and bicycle facilities that vary from reconstruction of a multi-use trail bridge and addition of lighting, to the installation of sidewalks in a suburban neighborhood, to the addition of bike lanes (City and Borough of Juneau, Alaska, 2014). Related CIP projects and funding amounts are listed in Table 7 below. 
Table 7 - Juneau CIP, Bicycle and Pedestrian Capital Projects, FY 2015

\begin{tabular}{|c|c|c|c|c|c|}
\hline Department $\quad \square$ & Project & Relevant Impact & Funding Source & Amount & it \\
\hline \multirow[t]{3}{*}{ Parks \& Recreation } & Waterfront Seawalk & Pedestrian & Marine Passenger Fee & $\$$ & 64,100 \\
\hline & Twin Lakes Multi Use Path Lighting & Bicycle, Pedestrian & Unscheduled - State Grant Request & $\$$ & 600,000 \\
\hline & Kaxdigoowu Heen Dei Trail Bridge Replacement & Bicycle, Pedestrian & Unscheduled - State Grant Request & $\$$ & 500,000 \\
\hline \multirow[t]{2}{*}{ Public Works } & Lakewood Subdivision Recon, Phase III & Pedestrian & Areawide Sales Tax & $\$$ & 950,000 \\
\hline & Eagles Edge Subdivision LID Improvements - Phase II & Pedestrian & Areawide Sales Tax & $\$$ & 500,000 \\
\hline
\end{tabular}

Note: Adapted from City and Borough of Juneau, Alaska, 2014

\subsubsection{Private Funding}

Juneau passed an ordinance in October 2005 that mandates a continuous pedestrian path along the entire downtown waterfront area to be included in all future development or redevelopment. This ordinance requires developers either construct their portion of the seawalk during the construction phase of their development, or pay the City and Borough in lieu fees equal to twenty percent of the final seawalk construction costs for the segment abutting their property (City and Borough of Juneau, 2005). The Downtown Waterfront 2025 Concept Plan also suggests that developers be responsible, or at least provide easements and fees, for public areas included in the plan (City and Borough of Juneau, 2004).

Other project private funding sources were indicated by the policy implementation and funding programming documents, but not specified.

\subsubsection{Shorewood, Wisconsin}

Key Local Funding Sources: Tax Increment Districts, General Obligation Bonds

For communities with the population size between 1,000 and 49,999, Shorewood, Wisconsin was one of three communities to receive seven points out of a total possible twelve points (see Table 8 below). Shorewood, a suburban community just north of central Milwaukee, WI, stood out for having important policy and funding in place, as well as a higher than average modal share for walking and transit, and a higher than average percentage of Safe Routes to School programming implemented. Shorewood is ranked by the League of American Bicyclists as a Bronze Community, and it is considered a Bronze Level Walk Friendly Community by the Pedestrian and Bicycle Info Center. 
Table 8 - Shorewood, WI Score

\begin{tabular}{|l|l|}
\hline City Data & Receive one point \\
\hline Bicycle Master plan & $\mathrm{Y}$ \\
\hline Pedestrian Master plan & $\mathrm{N}$ \\
\hline Pedestrian and Bicycle Plan & $\mathrm{N}$ \\
\hline $\begin{array}{l}\text { Pedestrian/Bicycle Planning Language in } \\
\text { Comprehensive Plan/Transportation Plan }\end{array}$ & $\mathrm{Y}$ \\
\hline Complete Streets Plan (Local) & $\mathrm{N}$ \\
\hline Plan Funding Component & $\mathrm{N}$ \\
\hline$\%$ of Commuter Mode Share - Bicycle & $</=5 \%$ \\
\hline$\%$ Commuter Modal Share - Walking & $>/=5 \%$ \\
\hline$\%$ Commuter Modal Share - Transit & $>/=5 \%$ \\
\hline$\%$ of Elementary Schools offering Bike Education & $>50 \%$ \\
\hline$\%$ of Middle Schools offering Bike Education & $>50 \%$ \\
\hline$\%$ of Arterial Streets with Bike Lanes & $>50 \%$ \\
\hline Total Score & $\mathbf{7}$ points \\
\hline
\end{tabular}

\subsubsection{Population and Demographics}

Shorewood, Wisconsin, has a population of 13,162 and covers a total area of 2.0 acres, with a population density of 8,356 and a median age of 37 years. The racial demographics are $88.1 \%$ White, 2.9\% Black, 0.2\% American Indian, and 5.6\% Asian (U.S. Census, 2010). Of the total population, 3.4\% classify themselves as Hispanic or Latino (U.S. Census, 2010).

\subsubsection{Policy Implementation}

- Comprehensive Plan: Transportation Element. The Transportation element of the Comprehensive Plan supports pedestrian safety and alternative transportation. It also includes a School Travel Plan with designated safe walking routes to school for two public elementary schools (Village of Shorewood, 2011).

- Comprehensive Bike Study. "The intent of this study is to establish plan objectives and planning criteria; identify safe and effective bicycle travel corridors; establish an education component to assure bicycle safety; and create an implementation process for future bicycle facilities (Village of Shorewood, 2011)." This study evaluates existing bicycle roadway facilities 
- Sustainable Action Plan. "The purpose of the action plan is to document the vision, goals, and actions for the Village of Shorewood in their efforts to adopt and implement sustainability in long-range planning, policy efforts, and daily operations (Village of Shorewood, 2012)." Implemented projects directed by the Sustainable Action Plan include the Pedestrian and Bicycle Safety Study and the installation of bike lanes throughout Capitol Drive and Oakland Avenue,

- Pedestrian and Bicycle Safety Study. "The goal of the study was to make recommendations that would improve the safety of those intersections and mid-block crossings for pedestrians and bicyclists (Village of Shorewood, 2011)."

- Tax Increment Districts. "Shorewood has four active Tax Increment Districts (TID). The first District was approved in 1995. TID \#5 was created July 2014 for the Metro Market development by General Capital for a grocery store and mixed use development along Oakland Avenue (Village of Shorewood, n.d.)." These TID's are re-development districts that are drawn around areas with the intent to improve the economic viability of the area. Each district has a finite statutory lifespan. Each TID project plan gives the Village the authority to "construct or reconstruct streets, highways, alleys, access drives and parking areas" (including the installation of sidewalks and bicycle lanes) as needed to benefit redevelopment of the area (Village of Shorewood, 2011). Additionally, the project plan gives the Village the authority to "install amenities to enhance development sites, rightsof-ways and other public spaces" to attract development, and threat them as eligible Project Costs (Village of Shorewood, 2011).

\subsubsection{Funding}

- General Fund. The Village of Shorewood strives to maintain $30 \%$ of the general fund as an unassigned fund balance. $25 \%$ of this unassigned balance provides a cushion for the following year's budget, and the remaining $5 \%$ can be used towards capital expenses, non-annually recurring expenses, and funding community investment expenses (Village of Shorewood, 2014). The only reference the 2014 Budget makes to pedestrian and 
bicycle facility implementation is to "maintain and improve private property and public infrastructure to maximize assessed value of all real estate (Village of Shorewood, 2013)." Part of this goal includes the installation of a projected number of square feet of concrete sidewalk.

- Tax Increment District. Bicycle and pedestrian capital improvements in the Village of Shorewood are largely accomplished through General Obligation (G.O.) taxable and taxexempt bonds facilitated and managed directly through each TID (Village of Shorewood, n.d.). An explicit detail of these expenditures was not found during a review of publicly available documents. 
5.2. Cities with Population Size: 50,000 - 99,999

Table 9 - City Scoring Matrix for Population Size 50K - 99,999

\begin{tabular}{|c|c|c|c|c|c|c|c|c|c|c|c|c|c|c|}
\hline \multicolumn{15}{|c|}{ Population size 50K - 99,999 } \\
\hline \multicolumn{2}{|c|}{ Green Criteria (1 pt.) } & $\mathbf{Y}$ & $\mathbf{Y}$ & $\mathbf{Y}$ & $\mathbf{Y}$ & $\mathbf{Y}$ & $\mathbf{Y}$ & $>/=5 \%$ & $>/=5 \%$ & $>/=5 \%$ & $>50 \%$ & $>50 \%$ & $>50 \%$ & \\
\hline & & \multicolumn{6}{|c|}{ Master Planning (policy \& funding) } & \multicolumn{3}{|c|}{ Commuter Mode Share } & \multicolumn{2}{|c|}{$\begin{array}{c}\text { Bicycle Education } \\
\text { Provision }\end{array}$} & \multicolumn{2}{|l|}{ Infrastructure } \\
\hline CitySTATE & Pop. size & Bike & Pedestrian & $\begin{array}{l}\text { Pedestrian \& } \\
\text { Bike }\end{array}$ & $\begin{array}{l}\text { Ped \& Bike } \\
\text { needs } \\
\text { addressed } \\
\text { in Plans }\end{array}$ & $\begin{array}{l}\text { Complete } \\
\text { Streets } \\
\text { Plan } \\
\text { (Local) }\end{array}$ & $\begin{array}{l}\text { Funding } \\
\text { Component }\end{array}$ & $\begin{array}{l}\% \\
\text { bicycle }\end{array}$ & $\begin{array}{l}\% \\
\text { walking }\end{array}$ & $\%$ transit & $\begin{array}{l}\% \\
\text { element } \\
\text { ary } \\
\text { schools }\end{array}$ & $\begin{array}{l}\% \text { middle } \\
\text { schools }\end{array}$ & $\begin{array}{l}\% \text { of arterial } \\
\text { streets with } \\
\text { bike lanes }\end{array}$ & $\begin{array}{l}\text { Total } \\
\text { Green }\end{array}$ \\
\hline Santa BarbaraCA & 88,410 & Y & Y & $\mathrm{N}$ & Y & Y & Y & $6 \%$ & $7 \%$ & $6 \%$ & $>90 \%$ & $>90 \%$ & N/A & 10 \\
\hline Santa MonicaCA & 89,736 & Y & $\mathrm{N}$ & $\mathrm{N}$ & $\mathrm{Y}$ & Y & $\mathrm{Y}$ & $3 \%$ & $5 \%$ & $4 \%$ & $1-25 \%$ & $>90 \%$ & $51-75 \%$ & 7 \\
\hline CorvallisOR & 54,462 & $\mathrm{~N}$ & $\mathrm{~N}$ & $\mathrm{~N}$ & $\mathrm{Y}$ & $\mathrm{N}$ & Y & $12 \%$ & $14 \%$ & $3 \%$ & $75-90 \%$ & $26-50 \%$ & $76-99 \%$ & 6 \\
\hline BendOR & 76,639 & $\mathrm{~N}$ & $\mathrm{~N}$ & $\mathrm{Y}$ & $\mathrm{Y}$ & $\mathrm{N}$ & Y & $2 \%$ & $3 \%$ & $1 \%$ & $51-75 \%$ & $1-25 \%$ & $76-99 \%$ & 5 \\
\hline Lee's SummitMO & 91,364 & Y & $\mathrm{N}$ & $\mathrm{N}$ & Y & Y & $\mathrm{N}$ & $0 \%$ & $1 \%$ & $0 \%$ & $51-75 \%$ & $51-75 \%$ & $26-50 \%$ & 5 \\
\hline FlagstaffAZ & 65,870 & $\mathrm{~N}$ & $\mathrm{~N}$ & $\mathrm{~N}$ & Y & Y & $\mathrm{N}$ & $5 \%$ & $10 \%$ & $2 \%$ & $26-50 \%$ & $0 \%$ & $26-50 \%$ & 4 \\
\hline RestonVA & 58,404 & $\mathrm{~N}$ & $\mathrm{~N}$ & $\mathrm{~N}$ & $\mathrm{~N}$ & $\mathrm{~N}$ & $\mathrm{~N}$ & $0 \%$ & $2 \%$ & $8 \%$ & $1-25 \%$ & $0 \%$ & $1-25 \%$ & 1 \\
\hline
\end{tabular}




\subsubsection{Santa Barbara, California}

Key Local Funding Sources: County Sales Tax Measure, Utility Users Tax

For cities with the population size between 50,000 and 99,999, Santa Barbara, CA received ten out of a possible twelve points (see Table 10 below), and ranked the highest of all cities studied. Santa Barbara stood out for having excellent coverage in policy, funding, and Safe Routes to School programming. Santa Barbara lags in percentage of arterial streets with bike lanes, and could improve in the area. Santa Barbara is ranked by the League of American Bicyclists as a Silver Community, and it is considered a Gold Level Walk Friendly Community by the Pedestrian and Bicycle Info Center.

Table 10 - Santa Barbara, CA Score

\begin{tabular}{|l|l|}
\hline City Data & Receive one point \\
\hline Bicycle Master plan & $\mathrm{Y}$ \\
\hline Pedestrian Master plan & $\mathrm{Y}$ \\
\hline Pedestrian and Bicycle Plan & $\mathrm{N}$ \\
\hline $\begin{array}{l}\text { Pedestrian/Bicycle Planning Language in } \\
\text { Comprehensive Plan/Transportation Plan }\end{array}$ & $\mathrm{Y}$ \\
\hline Complete Streets Plan (Local) & $\mathrm{Y}$ \\
\hline Plan Funding Component & $\mathrm{Y}$ \\
\hline$\%$ of Commuter Mode Share - Bicycle & $>/=5 \%$ \\
\hline$\%$ Commuter Modal Share - Walking & $>/=5 \%$ \\
\hline$\%$ Commuter Modal Share - Transit & $>/=5 \%$ \\
\hline$\%$ of Elementary Schools offering Bike Education & $>50 \%$ \\
\hline$\%$ of Middle Schools offering Bike Education & $>50 \%$ \\
\hline$\%$ of Arterial Streets with Bike Lanes & $<50 \%$ \\
\hline Total Score & $\mathbf{1 0}$ points \\
\hline
\end{tabular}

\subsubsection{Population and Demographics}

Santa Barbara, California, has a population of 88,410 and covers a total area of 42 acres, with a population density of 4,500 and a median age of 37 years. The racial demographics are $75.1 \%$ White, 1.6\% Black, 1.0\% American Indian, 3.5\% Asian, and 0.1\% Native Hawaiian (U.S. Census, 2010). Of the total population, $38.0 \%$ classify themselves as Hispanic or Latino (U.S. Census, 2010). 


\subsubsection{Policy Implementation}

The City of Santa Barbara has developed extensive policy documents that deal with pedestrian and bicyclist concerns. As implementation tools of the City's Circulation Element, the City developed a Pedestrian Master Plan and a Bicycle Master Plan. The Pedestrian Master Plan was updated in April 2006, and the Bicycle Master Plan was most recently updated in 2008 (City of Santa Barbara, 2013). The City's Circulation Element also acts as its Complete Streets Policy, as it is in compliance with the "California Complete Streets Act of 2008 that requires cities and counties to include complete streets policies as part of their general plans so that roadways are designed to safely accommodate all users, including bicyclists, pedestrians, transit riders, children, older people, and disabled people, as well as motorists (City of Santa Barbara, 2013)."

\subsubsection{Funding}

The City of Santa Barbara relies heavily on funding from Measure A, the $1 / 2$ cent sales tax approved by Santa Barbara County voters in November 2008, which is in effect from April 1, 2010 until March 31, 2040 (Santa Barbara County Local Transportation Authority, 2012). The City uses funds generated by Measure A for a variety of transportation projects including pedestrian and bicycle facilities, support for local transit, local road improvements, and local street and sidewalk infill and maintenance programs.

The Santa Barbara Council of Area Governments (SBCAG) oversees distribution of Measure A funds and is responsible for completing regional transportation projects. SBCAG allocates Measure A funds to the City's Streets Capital Program for local transportation projects within the City. Based on population, the City of Santa Barbara is slated to receive an estimated net 30 year allocation of $\$ 104,054,000$ for local street and transportation improvements. $26.05 \%$ of that funding, or an estimated $\$ 27,106,067$, is required to be directly allocated to the Santa Barbara Metropolitan Transit District (SMMTD) (Santa Barbara County Local Transportation Authority, 2012). Per the Measure A Investment Plan, the City of Santa Barbara must spend $10 \%$ of its allocation on eligible alternative transportation projects, and can spend the revenues on relevant eligible projects, which include: 
- Maintaining, improving or constructing roadways, bridges, and bicycle, and pedestrian facilities

- Safe Routes to Schools improvements

- Matching funds for state and regional programs and projects

- Maintenance, repair, construction, and improvement of bicycle, and pedestrian facilities, excluding maintenance of Class 2 bikeway facilities.

The City of Santa Barbara's bicycle, pedestrian and streetscape infrastructure projects programmed through Measure A in the fiscal year 2014/2015 are listed in Table 11 below.

Table 11 - Measure A Program of Projects - City of Santa Barbara, FY 2014/15

\begin{tabular}{|c|c|c|c|c|c|c|c|c|c|c|c|c|c|c|c|c|c|c|}
\hline \multicolumn{2}{|c|}{$\begin{array}{l}\text { Bicycle and Pedestrian Program/Safe } \\
\text { Routes to Schools }\end{array}$} & \multicolumn{10}{|c|}{ Measure A Revenues } & \multicolumn{5}{|c|}{ Non-Measure A Revenues } & \multicolumn{2}{|c|}{\begin{tabular}{|l} 
Ttl Project \\
Cost
\end{tabular}} \\
\hline & & \multicolumn{2}{|c|}{$\begin{array}{l}\text { FY 14/15 (includes } \\
\text { carry-over) }\end{array}$} & \multicolumn{2}{|l|}{ FY 15/16 } & \multicolumn{2}{|c|}{ FY $17 / 18$} & \multicolumn{2}{|c|}{ FY $18 / 19$} & \multicolumn{2}{|c|}{ TOTAL } & Local & \multirow{2}{*}{\begin{tabular}{|l|} 
State \\
$\$-$ \\
\end{tabular}} & \multicolumn{2}{|c|}{ Federal } & Total & & \\
\hline \multicolumn{2}{|c|}{ Available Revenues (\$MIL) } & $\$$ & $1,100.1$ & $\$$ & - & $\$$ & - & $\$$ & - & & $1,100.1$ & $\$ \quad-$ & & $\$$ & - & $\$ \quad-$ & & \\
\hline \multirow[t]{2}{*}{ Project ID } & \multicolumn{18}{|c|}{ Project Descriptions \& Expenditures (\$MIL) } \\
\hline & $\begin{array}{l}\text { Upper De La Vina } \\
\text { Pedestrian Crossing } \\
\text { Enhancements }\end{array}$ & $\$$ & - & $\$$ & 82.9 & $\$$ & - & $\$$ & - & $\$$ & 82.9 & $\$ 104.5$ & $\$-$ & $\$$ & - & $\$ 104.5$ & $\$$ & 187.4 \\
\hline MSA-17-2-9 & \begin{tabular}{|l|} 
Bicycle Facilities \\
Improvement Project
\end{tabular} & $\$$ & 50.0 & $\$$ & - & $\$$ & - & $\$$ & - & $\$$ & 50.0 & $\$ 25.0$ & $\$-$ & $\$$ & - & $\$ 25.0$ & $\$$ & 75.0 \\
\hline MSA-16-2-3 & $\begin{array}{l}\text { North La Cumbre Road } \\
\text { Sidewalk and Pedestrian } \\
\text { Safety } \\
\text { Improvements }\end{array}$ & $\$$ & 238.0 & $\$$ & - & $\$$ & - & $\$$ & - & $\$$ & 266.8 & $\$ 178.0$ & $\$-$ & $\$$ & - & $\$ 178.0$ & $\$$ & 444.8 \\
\hline MSA-16-2-4 & $\begin{array}{l}\text { School Zone Pedestrian } \\
\text { Refuge Islands }\end{array}$ & $\$$ & - & $\$$ & 134.7 & $\$$ & - & $\$$ & - & $\$$ & 134.7 & $\$ 65.0$ & $\$-$ & $\$$ & - & $\$ 65.0$ & $\$$ & 199.7 \\
\hline MSA-16-2-7 & $\begin{array}{l}\text { Santa Barbara School } \\
\text { Route Access Ramps }\end{array}$ & $\$$ & - & $\$$ & 22.3 & $\$$ & - & $\$$ & - & $\$$ & 22.3 & $\$ 14.3$ & $\$-$ & $\$$ & - & $\$ 14.3$ & $\$$ & 36.6 \\
\hline
\end{tabular}

Note: Adapted from Santa Barbara County Association of Governments, 2014

\subsubsection{General Fund}

The City's general fund is "used to account for the traditional services associated with local government, including public safety (fire and police), parks, recreation, streets maintenance and library services. As a full-service city, the general fund also accounts for community developmentrelated services, such as building, planning, and land development services; engineering services; maintenance of street lights; and environmental programs" (City of Santa Barbara, 2014). The Streets Fund is a special revenue fund that accounts for all of the "City-funded streets operations, maintenance and capital" (City of Santa Barbara, 2014). Nearly seventy percent of the Streets Fund revenue is supplied by the City's utility user's tax. Fifty percent of the "utility user's tax is restricted for use for streets operations, maintenance, and capital" (City of Santa Barbara, 2014). 


\subsubsection{Capital Improvement Program}

Very few transportation projects were approved in the fiscal year 2015 city budget. As shown in Table 12, two of the relevant approved projects received federal funding, and one is funded by Measure A.

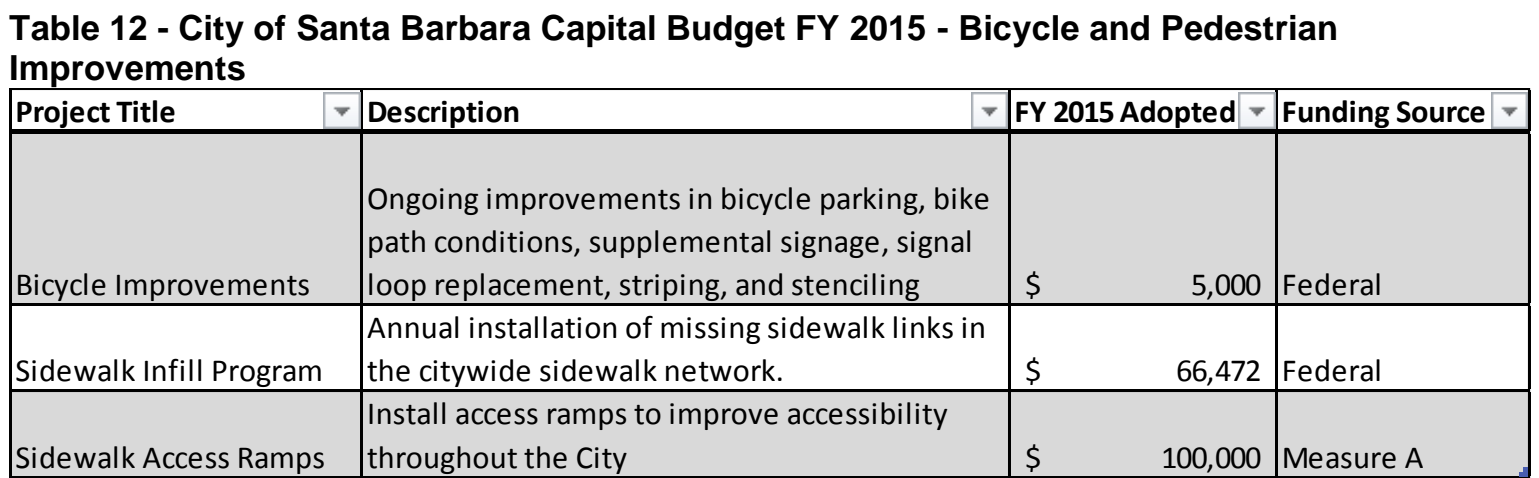

Note: Adapted from City of Santa Barbara, 2014

\subsubsection{Private Funding}

Documentation from the City of Santa Barbara points to a desire to use private funding or a public/private partnership for bicycle and pedestrian facilities on abutting property, where new development or redevelopment is scheduled to occur.

\subsubsection{Santa Monica, California}

Key Local Funding Sources: Transportation Impact Fee, Developer Agreements, Sales Tax Measures

For cities with the population size between 50,000 and 99,999, Santa Monica, California ranked second out of seven cities, and received seven points out of a total possible twelve points (see Table 13 below). For its size, Santa Monica ranked highly for having important policy and funding in place, as well as a higher than average modal share for walking, and a higher than average percentage of Safe Routes to School programming implemented in middle schools and high schools. Santa Monica is lacking a pedestrian master plan, and can improve its bicycling and transit commuter modes, as well as the percentage of elementary schools with Safe Routes to 
School programming. Santa Monica is ranked by the League of American Bicyclists as a Silver Community, and it is considered a Silver Level Walk Friendly Community by the Pedestrian and Bicycle Info Center.

Table 13 - Santa Monica, CA Score

\begin{tabular}{|l|l|}
\hline City Data & Receive one point \\
\hline Bicycle Master plan & $\mathrm{Y}$ \\
\hline Pedestrian Master plan & $\mathrm{N}$ \\
\hline Pedestrian and Bicycle Plan & $\mathrm{N}$ \\
\hline $\begin{array}{l}\text { Pedestrian/Bicycle Planning Language in } \\
\text { Comprehensive Plan/Transportation Plan }\end{array}$ & $\mathrm{Y}$ \\
\hline Complete Streets Plan (Local) & $\mathrm{Y}$ \\
\hline Plan Funding Component & $\mathrm{Y}$ \\
\hline$\%$ of Commuter Mode Share - Bicycle & $</=5 \%$ \\
\hline$\%$ Commuter Modal Share - Walking & $>/=5 \%$ \\
\hline$\%$ Commuter Modal Share - Transit & $</=5 \%$ \\
\hline$\%$ of Elementary Schools offering Bike Education & $<50 \%$ \\
\hline$\%$ of Middle Schools offering Bike Education & $>50 \%$ \\
\hline$\%$ of Arterial Streets with Bike Lanes & $>50 \%$ \\
\hline Total Score & 7 points \\
\hline
\end{tabular}

\subsubsection{Population and Demographics}

Santa Monica, CA, has a population of 89,736 and covers a total area of 8.3 acres with a population density of 10,807 and a median age of 40 years. The racial demographics are $77.6 \%$ White, 3.9\% Black, 0.4\% American Indian, and 9.0\% Asian (U.S. Census, 2010). Of the total population, $13.1 \%$ classify themselves as Hispanic or Latino (U.S. Census, 2010).

\subsubsection{Policy Implementation}

The City updated their Land Use and Circulation Element of the General Plan in 2010. This update was adopted on July 6, 2010. This update proposes "the creation of a multi-modal transportation system that minimizes and, where possible, eliminates pollution and motor vehicle congestion while ensuring safe mobility and access for all without compromising our ability to protect public health and safety" (City of Santa Monica, 2010). With the goal of creating "no net new evening peak period vehicle trips," the plan set the stage for the creation of funds and 
facilities aimed at encouraging an increase the implementation of viable multi-modal options (City of Santa Monica, 2010).

The City of Santa Monica adopted a Bicycle Master plan in 2011. According to the Master plan, "the Plan supports efforts to collaborate with community partners including businesses, employers and schools. [The] Plan is expected to meet state Bicycle Transportation Account requirements, making the City eligible to apply for state funding pursuant to that legislation...it allows for variation based on funding decisions and outside grant availability" (City of Santa Monica, 2011). For each facility proposed in this plan, a street cross-section, road conditions, route descriptions, and conceptual construction cost estimate are provided for either the 5 year or 20 year proposed enhancement cycle. This conceptual cost information and proposed project detail are provided as a guide in aiding grant submittals and budgeting (City of Santa Monica, 2011). The City is expected to have a draft Pedestrian Action Plan available for public review by early 2015 .

\subsubsection{General Fund, Special Revenue Fund and Private Funding}

Santa Monica City revenues are organized into three major categories, the general fund, special revenue and proprietary.

The City's general fund "supports essential City services such as police and fire protection, street maintenance, libraries, parks, and open space management (City of Santa Monica, 2011)."

The special revenue funds "are used to account for specific revenues that are legally restricted to expenditures for specified purposes (City of Santa Monica, 2011)." Relevant bicycle, pedestrian and streetscape infrastructure projects have funding allocated from the general fund and these special revenue funds (see Table 14 below). The three revenue sources funding these projects are (City of Santa Monica, 2011):

- Special Revenue Source Fund - Holds mitigation funds from developers' agreements.

- Community Development Block Grant Fund - holds federal entitlement funds under the Housing and Community Development Act of 1974.

- Miscellaneous Grants Fund - Holds miscellaneous federal, state, and county awarded grants and special allocations. 
The Special Revenue Source Fund includes revenues collected from the Transportation Impact Fee (TIF) program. This fee was adopted by ordinance on February 25, 2013. Under this ordinance, the City was divided into three impact areas, and transportation impact fees are assigned to new developments and intensified land uses based on development type and impact area. The fee is meant to translate the impact of new development into implementing the goals of the Land Use and Circulation Element (City of Santa Monica, 2013).

The Miscellaneous Grants Fund benefits from a Los Angeles County voter approved Measure R. Measure $\mathrm{R}$ is a half-cent sales tax to "finance new transportation projects and programs, and accelerate those already in the pipeline" (Metro, 2013). This took effect in July 2009 for a period of 30 years (Measure R: Traffic relief and rail expansion ordinance, 2009). In Santa Monica, these funds help to pay for bikeway, pedestrian improvements and streetscapes as they relate to the expansion of the Metro Light Rail (EXPO Line) through downtown Santa Monica (Los Angeles County Metropolitan Transportation Authority, 2008).

Table 14 - City of Santa Monica Relevant CIP Projects FY 2014-16

\begin{tabular}{|c|c|c|c|c|c|c|c|c|c|c|c|c|}
\hline \multirow[b]{2}{*}{ California Incline - Pedestrian Overcrossing } & \multirow[b]{2}{*}{$\begin{array}{l}\text { Description } \\
\text { Structural and drainage } \\
\text { improvements to the existing } \\
\text { California Incline Pedestrian } \\
\text { Overcrossing. } \\
\end{array}$} & \multirow[b]{2}{*}{$\begin{array}{l}\text { Funding Source } \\
\text { General Fund } \\
\end{array}$} & \multicolumn{2}{|c|}{ FY14-15 } & \multicolumn{2}{|c|}{ FY15-16 - } & \multicolumn{2}{|c|}{ FY16-17 } & \multicolumn{2}{|c|}{ FY17-18 -} & \multicolumn{2}{|c|}{ FY18-19= } \\
\hline & & & $\$$ & 433,500 & & - & & $\$ 1,076,400$ & & $\$$ & $\$$ & - \\
\hline $\begin{array}{l}\text { California Incline Bridge Replacement } \\
\text { Construction }\end{array}$ & $\begin{array}{l}\text { Reconstruct the Calfornia Incline } \\
\text { roadway - improve access for } \\
\text { pedestrians and bicyclists. }\end{array}$ & Special Revenue Source & $\$$ & 389,157 & & - & $\$$ & - & & $\$$ & $\$$ & - \\
\hline & & Misc. Grants & & $19,272,525$ & & $\$$ & \$ & - & & - & $\$$ & - \\
\hline & & Water Fund & & $1,100,000$ & & - & \$ & - & & - & $\$$ & - \\
\hline $\begin{array}{l}\text { Crosswalk Improvement and Repair } \\
\text { Program - new locations/infrastructure }\end{array}$ & & General Fund & $\$$ & 50,000 & & $\$ 50,000$ & & 50,000 & & $\$ 50,000$ & & 50,000 \\
\hline Crosswalk Improvements & $\begin{array}{l}\text { Improve and/or repair existing } \\
\text { crosswalks to increaese } \\
\text { pedestrian visibility or safety }\end{array}$ & General Fund & $\$$ & 100,000 & & $\$ 100,000$ & & $\$ 100,000$ & & $\$ 100,000$ & & 100,000 \\
\hline Berkeley Street Traffic Improvements & $\begin{array}{l}\text { Construct two median islands } \\
\text { and a traffic circle on Berkeley } \\
\text { Street and channelizers near the } \\
\text { intersection of } \\
\text { Berkeley Street and Wilshire } \\
\text { Boulevard. }\end{array}$ & General Fund & $\$$ & 110,000 & & $\$$ & & $\$ 445,000$ & & $\$$ & $\$$ & - \\
\hline Michigan Ave. Neighborhood MANGo & $\begin{array}{l}\text { Address speeding and safety } \\
\text { issues for cyclists and } \\
\text { pedestrians along the MANGo } \\
\text { corridor }\end{array}$ & General Fund & $\$$ & - & & $\$ 200,000$ & $\$$ & - & & $\$$ & $\$$ & - \\
\hline & & CDBG Fund & $\$$ & 366,943 & & $\$-$ & & - & & - & $\$$ & - \\
\hline Hospital Area Pedestrian Improvements & $\begin{array}{l}\text { Construction of new pedestrian } \\
\text { safety improvements, including } \\
\text { lighting upgrades }\end{array}$ & General Fund & $\$$ & - & & $\$ 110,000$ & & $\$ 230,000$ & & $\$ 375,000$ & $\$$ & - \\
\hline Colorado Avenue Esplanade & $\begin{array}{l}\text { Multi-modal streetscape and } \\
\text { circulation project. }\end{array}$ & Misc. Grants & & $2,415,000$ & & $\$$ & $s$ & - & & $\$$ & $\$$ & - \\
\hline & & Water Fund & $\$$ & 250,000 & & $\$$ & $\$$ & - & & - & $\$$ & - \\
\hline & & Wastewater Fund & $\$$ & 750,000 & & $\$$ & & - & & - & $\$$ & - \\
\hline $\begin{array}{l}\text { Bike Network Linkages to EXPO Light Rail } \\
\text { Transit (LRT) }\end{array}$ & $\begin{array}{l}\text { Upgrade to bicycle lanes and } \\
\text { connections to EXPO Stations }\end{array}$ & Misc. Grants & & $2,200,391$ & & $\$$ & $\$$ & - & & - & $\$$ & - \\
\hline
\end{tabular}

Note: Adapted from City of Santa Monica, 2011 
5.3. Cities with Population Size: 100,000 - 299,999

Table 15 - City Scoring Matrix for Population Size 100K - 299,999

\begin{tabular}{|c|c|c|c|c|c|c|c|c|c|c|c|c|c|c|}
\hline & & & & & & Population & ize $100 \mathrm{~K}-29$ & 999 & & & & & & \\
\hline Green Crite & (1 pt.) & $\mathbf{Y}$ & $Y$ & $\mathbf{Y}$ & $\mathbf{Y}$ & $Y$ & $Y$ & $>/=5 \%$ & $>/=5 \%$ & $>/=5 \%$ & $>50 \%$ & $>50 \%$ & $>50 \%$ & \\
\hline & & & & laster Plannin & (policy \& fun & ling) & & Comn & uter Mode & Share & $\begin{array}{l}\text { Bicycle Ed } \\
\text { Provis }\end{array}$ & $\begin{array}{l}\text { ucation } \\
\text { ion }\end{array}$ & Infrastructure & \\
\hline CitySTATE & Pop. size & Bicycle & Pedestrian & $\begin{array}{l}\text { Pedestrian } \\
\text { \& Bike }\end{array}$ & $\begin{array}{l}\text { Ped \& Bike } \\
\text { needs } \\
\text { addressed } \\
\text { in Plans }\end{array}$ & $\begin{array}{l}\text { Complete } \\
\text { Streets } \\
\text { Plan } \\
\text { (Local) }\end{array}$ & $\begin{array}{l}\text { Funding } \\
\text { Component }\end{array}$ & $\begin{array}{l}\% \\
\text { bicycle }\end{array}$ & $\begin{array}{l}\% \\
\text { walking }\end{array}$ & $\begin{array}{l}\% \\
\text { transit }\end{array}$ & $\begin{array}{l}\% \\
\text { elementary } \\
\text { schools }\end{array}$ & $\begin{array}{l}\% \\
\text { middle } \\
\text { schools }\end{array}$ & $\begin{array}{l}\% \text { of arterial } \\
\text { streets with } \\
\text { bike lanes }\end{array}$ & Total Green \\
\hline Fort CollinsCo & 143,986 & Y & Y & N & Y & Y & Y & $7 \%$ & $3 \%$ & $1 \%$ & $75-90 \%$ & $51-75 \%$ & $76-99 \%$ & 9 \\
\hline GainesvilleFL & 124,354 & $\mathrm{~N}$ & $\mathrm{~N}$ & $\mathrm{~N}$ & Y & Y & Y & $6 \%$ & $6 \%$ & $6 \%$ & $>90 \%$ & $>90 \%$ & $76-99 \%$ & 9 \\
\hline RochesterMN & 106,769 & Y & $\mathrm{N}$ & Y & Y & Y & Y & $1 \%$ & $5 \%$ & $5 \%$ & $26-50 \%$ & $1-25 \%$ & $1-25 \%$ & 7 \\
\hline LouisvilleKY & 256,231 & Y & Y & N & Y & Y & Y & $0 \%$ & $2 \%$ & $3 \%$ & $26-50 \%$ & $1-25 \%$ & $51-75 \%$ & 6 \\
\hline AlexandriaVA & 139,966 & N & $\mathrm{N}$ & Y & N & Y & N & $1 \%$ & $4 \%$ & $20 \%$ & $75-90 \%$ & $26-50 \%$ & $1-25 \%$ & 4 \\
\hline DaytonOH & 141,527 & Y & $\mathrm{N}$ & N & N & Y & $\mathrm{N}$ & $1 \%$ & $8 \%$ & $5 \%$ & $1-25 \%$ & $26-50 \%$ & $1-25 \%$ & 4 \\
\hline RochesterNY & 210,565 & Y & N & N & $\mathrm{N}$ & Y & $\mathrm{N}$ & $1 \%$ & $6 \%$ & $8 \%$ & $1-25 \%$ & $1-25 \%$ & $1-25 \%$ & 4 \\
\hline CaryNC & 135,234 & $\mathrm{~N}$ & $\mathrm{~N}$ & $\mathrm{~N}$ & Y & Y & $Y$ & $0 \%$ & $1 \%$ & $1 \%$ & $0 \%$ & $0 \%$ & $1-25 \%$ & 3 \\
\hline
\end{tabular}




\subsubsection{Fort Collins, Colorado}

Key Local Funding Sources: Sales Tax Measures, General Fund, Transportation Impact Fees For cities with the population size between 100,000 and 299,999, Fort Collins, CO was one of two cities to receive nine out of a possible twelve points (see Table 16 below). Fort Collins ranked highly for having excellent consistency among its policy documents, and good coverage in funding, Safe Routes to School programming, and arterial streets with bike lanes. It lags in its commuter modal share for walking and transit. Fort Collins is ranked by the League of American Bicyclists as a Platinum Community, and it is considered a Bronze Level Walk Friendly Community by the Pedestrian and Bicycle Info Center.

Table 16 - Fort Collins, co Score

\begin{tabular}{|l|l|}
\hline City Data & Receive one point \\
\hline Bicycle Master plan & $\mathrm{Y}$ \\
\hline Pedestrian Master plan & $\mathrm{Y}$ \\
\hline Pedestrian and Bicycle Plan & $\mathrm{N}$ \\
\hline $\begin{array}{l}\text { Pedestrian/Bicycle Planning Language in } \\
\text { Comprehensive Plan/Transportation Plan }\end{array}$ & $\mathrm{Y}$ \\
\hline Complete Streets Plan (Local) & $\mathrm{Y}$ \\
\hline Plan Funding Component & $\mathrm{Y}$ \\
\hline$\%$ of Commuter Mode Share - Bicycle & $>/=5 \%$ \\
\hline$\%$ Commuter Modal Share - Walking & $</=5 \%$ \\
\hline \% Commuter Modal Share - Transit & $</=5 \%$ \\
\hline \% of Elementary Schools offering Bike Education & $>50 \%$ \\
\hline$\%$ of Middle Schools offering Bike Education & $>50 \%$ \\
\hline$\%$ of Arterial Streets with Bike Lanes & $>50 \%$ \\
\hline Total Score & $\mathbf{9}$ points \\
\hline
\end{tabular}

\subsubsection{Population and Demographics}

Fort Collins, Colorado, has a population of 143,986 and covers a total area of 47 acres with a population density of 3,130 and a median age of 30 years. The racial demographics are $89.0 \%$ White, 1.2\% Black, 0.6\% American Indian, 2.9\% Asian, and 0.1\% Native Hawaiian (U.S. Census, 2010). Of the total population, $10.1 \%$ classify themselves as Hispanic or Latino (U.S. Census, 2010). 


\subsubsection{Policy Implementation}

The City of Fort Collins developed the 2010-11 Transportation Master Plan (TMP) in collaboration with the City Plan update. Per the City, the plan acts as a "connecting document" that links to the implementation plans for each element of the TMP (City of Fort Collins, 2011). The implementation plans include the City's Master Street Plan (MSP), multimodal transportation Capital Improvement Plan (CIP), Pedestrian Plan, and Bicycle Plan (City of Fort Collins, 2011). The TMP is organized to match the City's transportation budgeting categories, and the plan includes projects that have been "sized to constraints" as well as a "ROW based on thresholds" (City of Fort Collins, 2011). The TMP includes a systems approach towards sustainability, the triple bottom line approach, where planning and decision-making incorporates human, economic, and environmental planning goals (City of Fort Collins, 2011).

\subsubsection{Capital Improvement Program}

The City of Fort Collins has a Transportation CIP that is supposed to be updated every two years, although the latest available version is from 2012. According to the Transportation CIP, it "presents a list of transportation projects that are needed to achieve the vision of the Transportation Master Plan" (City of Fort Collins, 2012). In addition to order of magnitude capital costs, operating and maintenance costs, and project need, project evaluation criteria are identified using criteria specific to project type (City of Fort Collins, 2012). Once adjusted for these criteria, the project may shift from its initial tier status up or down in priority in the cost adjusted category. See Table 17 below as an example of the application of the performance criteria to all Bicycle Projects from the 2012 Transportation CIP. 
Table 17 - City of Fort Collins CIP

\begin{tabular}{|c|c|c|c|c|c|c|c|c|c|c|c|}
\hline \multicolumn{12}{|c|}{ Bicycle Projects } \\
\hline Location/Program & Descripton & Tier & $\begin{array}{l}\text { Cost } \\
\text { Magnitude }\end{array}$ & $\begin{array}{l}\text { Integrated } \\
\text { Land Use and } \\
\text { Transporation }\end{array}$ & $\begin{array}{l}\text { Mobility } \\
\text { Options }\end{array}$ & $\begin{array}{l}\text { Traffic } \\
\text { Flow }\end{array}$ & $\begin{array}{l}\text { Quality Travel } \\
\text { Infrastructure }\end{array}$ & $\begin{array}{l}\text { Increase } \\
\text { Awareness }\end{array}$ & \begin{tabular}{|l|} 
Cost \\
Adjusted \\
Vision \\
Score
\end{tabular} & $\begin{array}{l}\text { Cost } \\
\text { Adjusted } \\
\text { Category }\end{array}$ & $\begin{array}{l}\text { Cumulativ } \\
\text { e Cost } \\
\text { (MIL) }\end{array}$ \\
\hline $\begin{array}{l}2 \text { Existing Need } \\
\text { Intersection } \\
\text { Projects }\end{array}$ & \begin{tabular}{|l} 
bicycle-related \\
intersection \\
improvements
\end{tabular} & 1 & 3 & 3 & 4 & 2 & 3 & 3 & 17.1 & Medium & 3.8 \\
\hline $\begin{array}{l}\text { Existing needs for } \\
\text { bicycle-related } \\
\text { intersection } \\
\text { improvements }\end{array}$ & $\begin{array}{l}\text { Existing needs for } \\
\text { bicycle lanes, shared } \\
\text { lane markings or other } \\
\text { bicycle infrastructure }\end{array}$ & 1 & 5 & 4 & 5 & 2 & 4 & 3 & 16.2 & Medium & 17.3 \\
\hline $\begin{array}{l}3 \text { Development- } \\
\text { Driven Street } \\
\text { Projects }\end{array}$ & $\begin{array}{l}\text { Development-driven } \\
\text { needs for bicycle } \\
\text { lanes, shared lane } \\
\text { markings or other } \\
\text { bicycle infrastructure }\end{array}$ & 2 & 4 & 3 & 4 & 2 & 3 & 3 & 15 & Medium & 25.1 \\
\hline \begin{tabular}{|l|}
2 Forecasted Need \\
Parking/Station \\
Projects
\end{tabular} & $\begin{array}{l}\text { Forecasted needs for } \\
\text { bike parking/stations }\end{array}$ & 3 & 2 & 3 & 3 & 1 & 2 & 2 & 14.7 & Medium & 25.8 \\
\hline $\begin{array}{l}26 \text { Forecasted Need } \\
\text { Street Projects }\end{array}$ & $\begin{array}{l}\text { Forecasted needs for } \\
\text { bicycle lanes, shared } \\
\text { lane markings or other } \\
\text { bicycle infrastructure }\end{array}$ & 3 & 6 & 4 & 5 & 2 & 4 & 3 & 14.6 & Medium & 58.2 \\
\hline & & & & & & & & tal 2012 Bicycle & Infrastructu & Are Projects & 130.2 \\
\hline
\end{tabular}

Note: Adapted from City of Fort Collins, 2012

\subsubsection{Funding}

The general fund provides a non-fixed annual subsidy to transportation (City of Fort Collins, 2011). For 2015 Budget Year, $21 \%$ of the total Transportation budget is subsidized by the general fund. In 2016, 26\% of the Transportation Budget is subsidized by the general fund (City of Fort Collins, 2014c). The general fund also contributes approximately $22 \%$ towards the Street Oversizing Fund, in recognition that new vehicle trips are also caused by regional increases and changed travel behavior (City of Fort Collins, 2014e). As shown in Table 18 below, the 2015-2016 Budget has no general fund monies directly allocated towards Bicycle and Pedestrian infrastructure projects (City of Fort Collins, 2014c).

The City of Fort Collins has a history of utilizing sales tax initiatives to pay for their infrastructure needs. They first passed an initiative in 1973, which helped fund a variety of city needs, including transportation infrastructure (City of Fort Collins, 2014). With the exception of 1981 through 1983, the City has consistently approved sales tax initiatives to fund public goods.

In November 2010, the voters passed Measure 2B - Keep Fort Collins Great, a \$0.85 percent sales tax. This sales tax measure is in effect from 2011 through 2021 and overlaps two previous 
capital improvement sales tax measures for four years, 2011-2015: Street Maintenance, $\$ 0.25$ cents, and Building on the Basics, $\$ 0.25$ cents (City of Fort Collins, 2014).

Keep Fort Collins Great has tax revenue forecasted for 2014 at \$22.0 million, and funding is allocated as follows (City of Fort Collins, 2014):

- $33 \%$ Street Maintenance and Repairs

- $17 \%$ Other Transportation Needs

- $11 \%$ Parks Maintenance and Recreation Services

- $11 \%$ Other Community Priorities

- $17 \%$ Police Services

- $11 \%$ Poudre Fire Authority

Bicycle, pedestrian and streetscape infrastructure fall into the Other Transportation Needs category. As of 2014 , this category was scheduled to receive $\$ 3.7$ million. In 2015 , only $\$ 500,000$ was allocated from this fund, and in 2016 , only $\$ 650,000$ is allocated (see Table 18).

The City of Fort Collins implemented a Street Oversizing Program in 1979, with revisions in 1988 and 1996 (City of Boulder, CO, 2003). The Program assesses a Transportation Impact Fee on all projects impacting traffic. "The fee includes funding for the growth-related share of transportation improvements that include bike lanes, pedestrian ways and transit as well as vehicle travel lanes (City of Boulder, CO, 2003)." The fee is assessed during the building permit application process. "Oversizing refers to the increase in size of a street when it serves more than local traffic. Each new development must provide local street access. Added costs for the oversized portion is shared by all who will benefit (City of Fort Collins, 2014a)."

Table 18 - City of Fort Collins - Funded and Approved Projects Budget Years 2015-2016

\begin{tabular}{|c|c|c|c|c|c|c|c|c|c|c|c|c|c|}
\hline \multirow{3}{*}{$\begin{array}{l}\text { Description } \\
\text { Pedestrian Sidewalk ADA }\end{array}$} & \multicolumn{4}{|c|}{ General Fund } & \multirow{2}{*}{\multicolumn{2}{|c|}{$\begin{array}{l}\text { Capital } \\
\text { Projects Fund }\end{array}$}} & \multirow{2}{*}{$\begin{array}{l}\text { Keep Fort Collins } \\
\text { Great }\end{array}$} & \multirow{2}{*}{\multicolumn{2}{|c|}{\begin{tabular}{|l} 
Building on \\
Basics
\end{tabular}}} & \multirow{2}{*}{\multicolumn{2}{|c|}{2015 Total }} & \multirow{2}{*}{\multicolumn{2}{|c|}{2016 Total }} \\
\hline & \multicolumn{2}{|c|}{ Dedicated } & \multicolumn{2}{|c|}{ Ongoing } & & & & & & & & & \\
\hline & $\$$ & - & $\$$ & - & $\$$ & - & $\$ \quad-$ & $\$$ & 300,000 & $\$$ & 300,000 & $\$$ & - \\
\hline $\begin{array}{l}\text { Pedestrian Sidewalk and Americans with } \\
\text { Disabilities Act Compliance Program }\end{array}$ & $\$$ & - & $\$$ & - & $\$$ & - & 150,000 & $\$$ & - & $\$$ & - & $\$$ & 150,000 \\
\hline Arterial Intersection & $\$$ & - & $\$$ & - & $\$$ & - & $\$$ & & $2,220,000$ & $\$$ & $2,220,000$ & $\$$ & - \\
\hline \multirow[t]{4}{*}{$\begin{array}{l}\text { Vine and Lemay Intersection } \\
\text { Improvements }\end{array}$} & $\$$ & - & $\$$ & - & $\$$ & - & $1,000,000$ & $\$$ & - & $\$$ & 500,000 & $\$$ & 500,000 \\
\hline & & & & & \multicolumn{5}{|c|}{ Total Bicycle and Pedestrian Infrastructure Projects } & $\$$ & $3,020,000$ & $\$$ & 650,000 \\
\hline & & & & & & & \multicolumn{3}{|c|}{ Total Transportation Budget } & $\$$ & $56,003,781$ & & $4,439,707$ \\
\hline & & & & & \multicolumn{5}{|c|}{ Percent of Total Transportation Budget } & & $\mathbf{5 \%}$ & & $1 \%$ \\
\hline
\end{tabular}

Note: Adapted from City of Fort Collins, $2014 \mathrm{C}$ 
The TMP recognizes that all of these funding sources combined still do not cover existing transportation funding needs, and that future ideas might include focus on in-fill development and context sensitive design of existing corridors (City of Fort Collins, 2011). Some of the unfunded projects in the 2015-2016 Budget included streetscape projects, a protected bike lane demonstration project, and bicycle and pedestrian grade separated projects (City of Fort Collins, 2014c).

\subsubsection{Gainesville, Florida}

Key Local Funding Sources: Tax Increment Financing District, Local Option Gas Tax Fund, Transportation Mobility Program Area Fees

For cities with the population size between 100,000 and 299,999, Gainesville, FL was one of two cities to receive nine out of a total possible twelve points (see Table 19 below). Gainesville ranked highly for having some important policy documents in place, a plan funding component, and excellent coverage in share of multi-modal commuters, Safe Routes to School programming, and arterial streets with bike lanes. It could improve its score by providing a higher number of implementing policy documents. Gainesville is ranked by the League of American Bicyclists as a Silver Community, and it is considered a Bronze Level Walk Friendly Community by the Pedestrian and Bicycle Info Center. 
Table 19 - Gainesville, FL Score

\begin{tabular}{|l|l|}
\hline City Data & Receive one point \\
\hline Bicycle Master plan & $\mathrm{N}$ \\
\hline Pedestrian Master plan & $\mathrm{N}$ \\
\hline Pedestrian and Bicycle Plan & $\mathrm{N}$ \\
\hline $\begin{array}{l}\text { Pedestrian/Bicycle Planning Language in } \\
\text { Comprehensive Plan/Transportation Plan }\end{array}$ & $\mathrm{Y}$ \\
\hline Complete Streets Plan (Local) & $\mathrm{Y}$ \\
\hline Plan Funding Component & $\mathrm{Y}$ \\
\hline$\%$ of Commuter Mode Share - Bicycle & $>/=5 \%$ \\
\hline$\%$ Commuter Modal Share - Walking & $>/=5 \%$ \\
\hline$\%$ Commuter Modal Share - Transit & $>/=5 \%$ \\
\hline$\%$ of Elementary Schools offering Bike Education & $>50 \%$ \\
\hline$\%$ of Middle Schools offering Bike Education & $>50 \%$ \\
\hline$\%$ of Arterial Streets with Bike Lanes & $>50 \%$ \\
\hline Total Score & $\mathbf{9}$ points \\
\hline
\end{tabular}

\subsubsection{Population and Demographics}

Gainesville, Florida, has a population of 124,354 , and covers a total area of 49.0 acres with a population density of 1,981 , and a median age of 25 years old. The racial demographics are 64.9\% White, 23.0\% Black, 0.3\% American Indian, 6.9\% Asian, and 0.1\% Native Hawaiian (U.S. Census, 2010). Of the total population, $10.0 \%$ classify themselves as Hispanic or Latino (U.S. Census, 2010).

\subsubsection{Policy Implementation}

The City of Gainesville relies heavily on their Metropolitan Transportation Planning Organization (MTPO) for long range bicycle and pedestrian planning. However, the City has fairly progressive Transportation Mobility Element as a part of their Comprehensive Plan. The Transportation Mobility Element was updated as of October 12, 2013, and incorporates Complete Streets language. Their overall goal for this element states (City of Gainesville, 2013):

...the transportation system shall be designed to meet the needs of pedestrians, bicyclists, transit, and auto users. Safety and efficiency shall be enhanced by limitations and care in locations of driveways, provision of sidewalk connections within developments, and an overall effort to enhance and encourage pedestrian mobility 
throughout the community by improvement and provision of safe crossings, complete sidewalk and trail systems, and sidewalks of adequate widths.

The Transportation Mobility Element also includes multi-modal level of service (LOS) criteria, and lays out the infrastructure for the Transportation Mobility Program Area (TMPA). The TMPA includes all property within the City limits, and establishes bicycle, pedestrian, and transit infrastructure and LOS requirements that must be met for each new development. The Comprehensive Plan also has a Capital Improvements Plan as one its elements.

\subsubsection{Funding}

The general fund "accounts for those resources and their uses traditionally associated with government, which are not required to be budgeted and accounted for in another fund. The general fund is the City's only major fund (City of Gainesville, 2012)." The general fund is mainly funded by taxes and transfers in. However, additional funding sources such as intergovernmental sources and miscellaneous revenues also make up part of the revenue that can be utilized for transportation (City of Gainesville, 2012). Table 20 below shows the split of some of the major funding sources and amounts that can be used for transportation capital projects.

Table 20 - City of Gainesville FY 2013 - 2014 General Funds (unique funding sources)

\begin{tabular}{|c|c|c|c|c|c|}
\hline \multicolumn{2}{|l|}{ Sources of Funds } & \multicolumn{2}{|c|}{ FY 2013 Adopted } & \multicolumn{2}{|c|}{ FY 2014 Plan } \\
\hline Taxes & Local Option Gas Tax & $\$$ & 778,970 & $\$$ & 791,317 \\
\hline Intergovernmental & Half Cents Sales Tax & $\$$ & $6,227,000$ & $\$$ & $6,448,183$ \\
\hline Intergovernmental & MTPO Contribution & $\$$ & 10,259 & $\$$ & 10,259 \\
\hline Miscellaneous Revenues & Rebate Gas Tax & $\$$ & 36,155 & $\$$ & 36,155 \\
\hline Miscellaneous Revenues & CRA Loan Interest & $\$$ & 155,506 & $\$$ & 144,874 \\
\hline Transfers to Other Funds & Tax Increment 5th Avenue & $\$$ & 172,408 & $\$$ & 170,198 \\
\hline Transfers to Other Funds & Tax Increment CP/UH & $\$$ & 925,118 & $\$$ & 910,864 \\
\hline Transfers to Other Funds & Tax Increment Downtown & $\$$ & 642,540 & $\$$ & 634,039 \\
\hline Transfers to Other Funds & Tax Increment Eastside & $\$$ & 188,831 & $\$$ & 185,449 \\
\hline & Totals & $\$$ & $9,136,787$ & $\$$ & $9,331,338$ \\
\hline
\end{tabular}

Note: Adapted from City of Gainesville, 2012

In both the FY 2013 and FY 2014 summary of uses, approximately $11 \%$ of the general fund is allocated towards Transportation (City of Gainesville, 2012). 
Feeding into the general fund, are a few key ways that the City is able to pay for bicycle, pedestrian and streetscape infrastructure. The City of Gainesville benefits from a "Florida law [that] authorizes local governments to impose several types of local option taxes" (Florida Department of Revenue, 2012).

- Local Option Gas Tax. Alachua County has two local options for increasing the gas tax imposed in their county. The first is $\$ 0.06$, and the second is $\$ 0.05$ (Florida Department of Revenue, 2013). By inter-local agreement the City of Gainesville receives $38.635 \%$ of the Additional \$0.05 Local Option Gas Tax Capital Projects Fund (City of Gainesville, 2012). These funds must be used for transportation-related expenditures. A portion of these funds also goes to the Regional Transit System to fund mass transit (City of Gainesville, 2002).

- Community Redevelopment Area Tax Increment Trust Funds. There are four tax increment districts in the City of Gainesville. One district is the downtown area, established in 1980. The second area is the Fifth Avenue district, established in 1979. The third district is College Park/University Heights, established in 1994. A fourth redevelopment district on the east side of Gainesville was established in November 2000 for development, and July 2010 for expansion areas (City of Gainesville, 2012). "The CRA receives the ad valorem tax funds over and above the tax levels as of the establishment dates in these districts to finance redevelopment projects in those areas. These funds can be used for infrastructure needs. However, the revenues from the 4 districts cannot be co-mingled and must be expended in the respective districts (City of Gainesville, 2002)." Many of the infrastructure projects listed in Table 21 below are a part of larger scale redevelopment efforts led by the City Redevelopment Agency for these four districts.

- Transportation Concurrency Exception Area (TCEA) - While the Transportation Mobility Data and Analysis Report indicated LOS deficiencies on several roadways (see Figure 24 in that report), the City has opted to use its adopted Transportation Concurrency Exception Area (TCEA) as the means of dealing with deficient LOS roads in 
the city. Implicit in this is the City's acceptance of certain levels of congestion is a desire to promote redevelopment and infill within city limits. The TCEA sets alternative standards that developments must meet to promote transportation choice and multimodal opportunities (City of Gainesville, 2002). The TCEA was repealed in 2013, and replaced by the Transportation Mobility Element, which sets the policy to allow the City to generate Transportation Mobility Program Area Fees (TMPA Revenues) (City of Gainesville, 2013). The TMPA includes all property within the City limits, divided into six zones, and requires that developers directly build, or pay the City to provide bicycle, pedestrian, and transit infrastructure and to meet LOS requirements for the intended zone. TMPA revenue is then placed into the TCEA fund.

\begin{tabular}{|c|c|c|c|c|c|c|c|c|}
\hline $\begin{array}{l}\text { Program } \\
\text { Number }\end{array}$ & Project Description & & $\begin{array}{l}\text { ected Total } \\
\text { Cost }\end{array}$ & & $\begin{array}{l}\text { st to the } \\
\text { City }\end{array}$ & $\begin{array}{c}\text { FY } \\
\text { Schedule }\end{array}$ & Revenue Sources & $\begin{array}{c}\text { Consistency with } \\
\text { Other Elements }\end{array}$ \\
\hline \multirow{3}{*}{28} & \multirow{3}{*}{$\begin{array}{c}\text { Depot Avenue Reconstruction with } \\
\text { sidewalks \& bike lanes (from SW } \\
\text { 13th St. to Williston Rd.) } \\
\end{array}$} & $\$$ & $3,680,000$ & $\$$ & 230,000 & $2012 / 2013$ & \multirow{3}{*}{$\begin{array}{l}\text { Local Option Fuel Tax ( } 5 \text { cents), } 2007 \\
\text { City Bond, LAP, County Incentive } \\
\text { Grant Program (CIPG), } 2015 \text { City Bond }\end{array}$} & \multirow{3}{*}{ Yes } \\
\hline & & $\$$ & $3,500,000$ & $\$$ & $2,910,000$ & $2013 / 2014$ & & \\
\hline & & $\$$ & 350,000 & $\$$ & 350,000 & $2014 / 2015$ & & \\
\hline \multirow{3}{*}{29} & \multirow{3}{*}{$\begin{array}{l}\text { SE 4th Street Reconstruction with } \\
\text { sidewalks \& bike lanes (from } \\
\text { Depot Ave. to Williston Rd.) }\end{array}$} & & & & & & \multirow{3}{*}{ Local Option Fuel Tax ( 5 cents) } & \multirow{3}{*}{ Yes } \\
\hline & & $\$$ & 250,000 & $\$$ & 250,000 & $2012 / 2013$ & & \\
\hline & & $\$$ & $4,300,000$ & $\$$ & 430,000 & $2013 / 2014$ & & \\
\hline 30 & $\begin{array}{l}\text { SW 35th Place sidewalk (from SW } \\
\text { 23rd Ter. To SW 34th St.) }\end{array}$ & $\$$ & 460,000 & $\$$ & 460,000 & $2013 / 2014$ & $\begin{array}{c}\text { Local Option Fuel Tax (5 cents), TMPA } \\
\text { revenues }\end{array}$ & Yes \\
\hline \multirow[t]{2}{*}{32} & \multirow{2}{*}{$\begin{array}{l}\text { NW 34th St. sidewalk (from NW } \\
\text { 55th Blvd. to US 441) }\end{array}$} & $\$$ & 84,500 & $\$$ & - & $2012 / 2013$ & \multirow[t]{2}{*}{ FDOT Funds } & \multirow[t]{2}{*}{ Yes } \\
\hline & & $\$$ & 399,500 & $\$$ & - & $2013 / 2014$ & & \\
\hline \multirow[t]{2}{*}{37} & \multirow{2}{*}{$\begin{array}{c}\text { SW 6th St. Reconstruction with } \\
\text { sidewalks \& bike lanes (from Univ. } \\
\text { Ave. to SW 4th Ave.) }\end{array}$} & $\$$ & 200,000 & $\$$ & 200,000 & $2013 / 2014$ & \multirow[t]{2}{*}{ Local Option Fuel Tax ( 5 cents) } & \multirow[t]{2}{*}{ Yes } \\
\hline & & $\$$ & $1,300,000$ & $\$$ & $1,300,000$ & $2014 / 2015$ & & \\
\hline 38 & $\begin{array}{c}\text { Sixth Street Rail Trail Project: } \\
\text { Section } 3 \text { (from SW 2nd Ave. to NW } \\
\text { 10th Ave.) }\end{array}$ & $\$$ & 665,000 & \multicolumn{2}{|l|}{$\$$} & $2013 / 2014$ & FDOT Funds & Yes \\
\hline 39 & $\begin{array}{l}\text { Main Street Streetscaping from } \\
\text { Depot Ave. to N 8th Ave. }\end{array}$ & $\$$ & $1,520,000$ & $\$$ & $1,520,000$ & $2013 / 2014$ & $\begin{array}{l}\text { Local Option Fuel Tax ( } 5 \text { cents), } \\
\text { Department of Energy Grant }\end{array}$ & Yes \\
\hline 41 & $\begin{array}{l}\text { NW 34th Boulevard/NW 23rd } \\
\text { Terrace sidewalks }\end{array}$ & & & $\$$ & 643,000 & $2012 / 2013$ & old TCEA & Yes \\
\hline \multirow{5}{*}{43} & \multirow{5}{*}{ Sidewalk construction } & $\$$ & 192,190 & $\$$ & 100,190 & $2012 / 2013$ & \multirow{5}{*}{ City General Fund, old TCEA, TMPA } & \multirow{5}{*}{ Yes } \\
\hline & & $\$$ & 100,000 & $\$$ & 100,000 & $2013 / 2014$ & & \\
\hline & & $\$$ & 100,000 & $\$$ & 100,000 & $2014 / 2015$ & & \\
\hline & & $\$$ & 100,000 & $\$$ & 100,000 & $2015 / 2016$ & & \\
\hline & & $\$$ & 100,000 & $\$$ & 100,000 & $2016 / 2017$ & & \\
\hline 46 & $\begin{array}{l}\text { NE 19th Place sidewalk (NE 9th St } \\
\text { to NE 15th St) }\end{array}$ & $\$$ & 218,000 & $\$$ & - & $2012 / 2013$ & FDOT Funds & Yes \\
\hline 48 & $\begin{array}{c}\text { SW 2nd Street Bike/Pedestrian } \\
\text { Connection (Depot Avenue to SW } \\
\text { 6th Avenue) }\end{array}$ & $\$$ & 62,700 & $\$$ & - & $2013 / 2014$ & CDBG & Yes \\
\hline 49 & $\begin{array}{c}\text { SW 2nd Street Bike/Pedestrian } \\
\text { Connection (Depot Avenue to SW } \\
\text { 6th Avenue) }\end{array}$ & $\$$ & 150,000 & $\$$ & 25,000 & $2019 / 2020$ & $\begin{array}{c}\text { TMPA, FDOT (included in FDOT } \\
\text { tentative work program FY } 2015 \text { - } \\
\text { FY2019) }\end{array}$ & Yes \\
\hline
\end{tabular}

Note: Adapted from City of Gainesville, 2014 
The City has previously benefited from regional sales tax measures. Alachua County had a One Half Percent Discretional Sales Surtax that expired in 2010. An 8 year, 1\% county sales tax measure was on the voting ballot for November 4, 2014, but lost with only $40 \%$ of voters approving the increase (Clark, 2014). 
5.4. Cities with Population Size: $>300,000$

Table 22 - City Scoring Matrix for Population Size $>\mathbf{3 0 0 , 0 0 0}$

\begin{tabular}{|c|c|c|c|c|c|c|c|c|c|c|c|c|c|c|}
\hline \multicolumn{15}{|c|}{ Population size $>\mathbf{3 0 0 , 0 0 0}$} \\
\hline \multicolumn{2}{|c|}{ Green Criteria (1 pt.) } & $\mathbf{Y}$ & $\mathbf{Y}$ & $\mathbf{Y}$ & $\mathbf{Y}$ & $\mathbf{Y}$ & $\mathbf{Y}$ & $>l=5 \%$ & $>1=5 \%$ & $>l=5 \%$ & $>50 \%$ & $>50 \%$ & $>50 \%$ & \\
\hline & & \multicolumn{6}{|c|}{ Master Planning (policy \& funding) } & \multicolumn{3}{|c|}{ Commuter Mode Share } & \multicolumn{2}{|c|}{ Bicycle Education Provision } & \multicolumn{2}{|l|}{ Infrastructure } \\
\hline CitySTATE & Pop. size & Bike & Pedestrian & $\begin{array}{l}\text { Pedestrian } \\
\text { \& Bike }\end{array}$ & $\begin{array}{l}\text { Ped \& Bike } \\
\text { needs addressed } \\
\text { in Plans }\end{array}$ & $\begin{array}{l}\text { Complete } \\
\text { Streets } \\
\text { Plan } \\
\text { (Local) }\end{array}$ & $\begin{array}{l}\text { Funding } \\
\text { Component }\end{array}$ & $\begin{array}{l}\% \\
\text { bicycle }\end{array}$ & $\begin{array}{l}\% \\
\text { walking }\end{array}$ & $\%$ transit & $\begin{array}{l}\text { \% elementary } \\
\text { schools }\end{array}$ & $\begin{array}{l}\text { \% middle } \\
\text { schools }\end{array}$ & $\begin{array}{l}\% \text { of arterial } \\
\text { streets with } \\
\text { bike lanes }\end{array}$ & $\begin{array}{l}\text { Total } \\
\text { Green }\end{array}$ \\
\hline Long BeachCA & 462,257 & $\mathrm{Y}$ & $\mathrm{N}$ & $\mathrm{N}$ & $\mathrm{Y}$ & $\mathrm{N}$ & $\mathrm{Y}$ & $1 \%$ & $3 \%$ & $7 \%$ & $>90 \%$ & $>90 \%$ & $51-75 \%$ & 7 \\
\hline MinneapolisMN & 382,578 & $\mathrm{Y}$ & $\mathrm{Y}$ & $\mathrm{N}$ & $\mathrm{Y}$ & $\mathrm{N}$ & $\mathrm{Y}$ & $3 \%$ & $6 \%$ & $14 \%$ & $>90 \%$ & $0 \%$ & $26-50 \%$ & $\%$ \\
\hline San FranciscoCA & 805,235 & $\mathrm{Y}$ & $\mathrm{Y}$ & $\mathrm{N}$ & $\mathrm{Y}$ & $\mathrm{Y}$ & $\mathrm{Y}$ & $3 \%$ & $10 \%$ & $32 \%$ & $1-25 \%$ & $1-25 \%$ & $1-25 \%$ & 7 \\
\hline WashingtonDC & 601,723 & Y & $\mathrm{Y}$ & $\mathrm{N}$ & $\mathrm{Y}$ & $\mathrm{Y}$ & $\mathrm{Y}$ & $3 \%$ & $12 \%$ & $40 \%$ & $1-25 \%$ & $1-25 \%$ & $1-25 \%$ & 7 \\
\hline PhiladelphiaPA & $1,526,006$ & $\mathrm{~N}$ & $\mathrm{~N}$ & Y & $\mathrm{Y}$ & $\mathrm{Y}$ & $\mathrm{N}$ & $2 \%$ & $8 \%$ & $27 \%$ & $51-75 \%$ & $1-25 \%$ & $26-50 \%$ & $\%$ \\
\hline CharlotteNC & 731,424 & $\mathrm{Y}$ & $\mathrm{N}$ & $\mathrm{N}$ & $\mathrm{Y}$ & $\mathrm{Y}$ & $\mathrm{Y}$ & $0 \%$ & $2 \%$ & $4 \%$ & $51-75 \%$ & $1-25 \%$ & $1-25 \%$ & $\%$ \\
\hline New OrleansLA & 343,829 & $\mathrm{~N}$ & $\mathrm{~N}$ & $\mathrm{~N}$ & $\mathrm{Y}$ & $\mathrm{Y}$ & $\mathrm{Y}$ & $2 \%$ & $6 \%$ & $8 \%$ & $1-25 \%$ & $0 \%$ & $1-25 \%$ & $\%$ \\
\hline AustinTX & 790,390 & $\mathrm{Y}$ & $\mathrm{N}$ & $\mathrm{N}$ & $\mathrm{N}$ & $\mathrm{Y}$ & $\mathrm{N}$ & $2 \%$ & $3 \%$ & $4 \%$ & $>90 \%$ & $1-25 \%$ & $51-75 \%$ & $\%$ \\
\hline OmahaNE & 408,958 & $\mathrm{~N}$ & $\mathrm{~N}$ & $\mathrm{~N}$ & $\mathrm{Y}$ & $\mathrm{N}$ & $\mathrm{N}$ & $0 \%$ & $3 \%$ & $2 \%$ & $26-50 \%$ & $1-25 \%$ & $1-25 \%$ & $\%$ \\
\hline
\end{tabular}




\subsubsection{Long Beach, California}

Key Local Funding Sources: Transportation Mitigation Program Fees, Successor Agency (RDA), County Sales Tax Measures

For cities with the population size greater than 300,000 , Long Beach, CA was one of four cities to receive seven out of a total possible twelve points (see Table 23 below). Long Beach ranked highly for having some important policy documents in place, a plan funding component, Safe Routes to School programming, and arterial streets with bike lanes. It could improve its score by providing a complete streets plan, and improving its commuter share of cyclists and pedestrians. Long Beach is ranked by the League of American Bicyclists as a Silver Community, and it is considered a Silver Level Walk Friendly Community by the Pedestrian and Bicycle Info Center.

Table 23 - Long Beach, CA Score

\begin{tabular}{|l|l|}
\hline City Data & Receive one point \\
\hline Bicycle Master plan & $\mathrm{Y}$ \\
\hline Pedestrian Master plan & $\mathrm{N}$ \\
\hline Pedestrian and Bicycle Plan & $\mathrm{N}$ \\
\hline $\begin{array}{l}\text { Pedestrian/Bicycle Planning Language in } \\
\text { Comprehensive Plan/Transportation Plan }\end{array}$ & $\mathrm{Y}$ \\
\hline Complete Streets Plan (Local) & $\mathrm{N}$ \\
\hline Plan Funding Component & $\mathrm{Y}$ \\
\hline$\%$ of Commuter Mode Share - Bicycle & $</=5 \%$ \\
\hline$\%$ Commuter Modal Share - Walking & $</=5 \%$ \\
\hline$\%$ Commuter Modal Share - Transit & $>/=5 \%$ \\
\hline$\%$ of Elementary Schools offering Bike Education & $>50 \%$ \\
\hline$\%$ of Middle Schools offering Bike Education & $>50 \%$ \\
\hline$\%$ of Arterial Streets with Bike Lanes & $>50 \%$ \\
\hline Total Score & 7 points \\
\hline
\end{tabular}

\subsubsection{Population and Demographics}

Long Beach, California, has a population of 462,257 and covers a total area of 65.9 acres with a population density of 9,150 and a median age of 33 years. The racial demographics are $46.1 \%$ White, 13.5\% Black, 0.7\% American Indian, 12.9\% Asian, and 1.1\% Native Hawaiian (U.S. Census, 2010). Of the total population, $40.8 \%$ classify themselves as Hispanic or Latino (U.S. Census, 2010). 


\subsubsection{Policy Implementation}

A downtown and transit-oriented development (TOD) pedestrian master plan has been funded and is currently in progress. The Mobility element of the City's General Plan was updated in October 2013. This element does not directly comply with the California Complete Streets Act in name, but does so in spirit. As a part of its vision of moving towards tomorrow, it "plans, maintains, and operates mobility systems consistent with the principles of complete streets, active living, and sustainable community design (City of Long Beach, 2013)." The City is undergoing a 2030 update to the General Plan, with plans to incorporate direct compliance with the CA Complete Streets Act (City of Long Beach, 2011).

\subsubsection{Local Funding Sources}

- General Fund. The City of Long Beach general fund represents approximately $14 \%$ of the total City budget, and is meant for City services such as streets and sidewalks repair (City of Long Beach, 2013). The City does not use the general fund to fund capital projects.

- Capital Improvement Program (CIP). The City of Long Beach utilizes the CIP to represent "expenditures for major construction and infrastructure projects" (City of Long Beach, 2013). Table 24 lists bicycle, pedestrian, and streetscape capital projects which were approved in the FY 2014 budget. These projects are programmed to receive funding from a variety of sources, including the TMP, Prop C, Measure R, and numerous State and Federal funds.

- Transportation Mitigation Program Fees (TMP). The TMP is a development impact fee that was adopted via ordinance in 1990, and is assessed on commercial and residential development projects in the City (City of Long Beach, 2013). The fees collected are required to be used on direct development impacts, and not City-wide issues (City of Long Beach, 2013). The TMP has not kept up with inflation since 1990, and falls short of the existing transportation infrastructure needs (City of Long Beach, 2013). 
Table 24 - FY 2014 CIP Program Transportation Enhancements - Bicycle, Pedestrian and Streetscape Projects

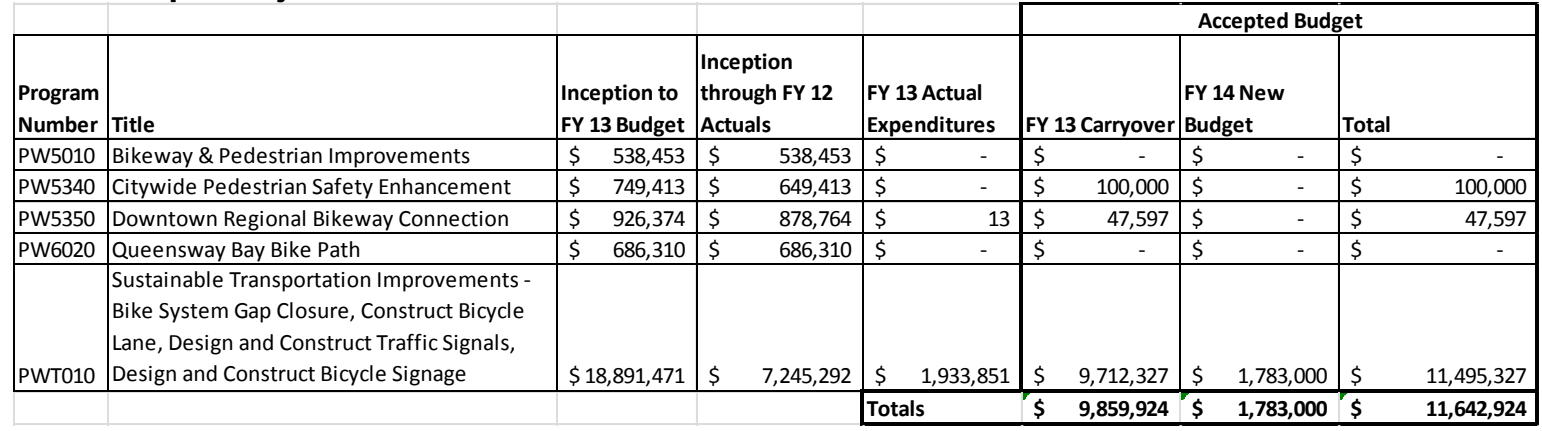

Note: Adapted from City of Long Beach, 2013

- Successor Agency (SA). The SA "is the successor entity to former Long Beach Redevelopment Agency (RDA)" (City of Long Beach, 2013). The SA was formed to implement RDA obligations, and ongoing Capital Projects. These total \$22.4 million through FY 2018, and can cover improvements to bicycle and pedestrian ROW (City of Long Beach, 2013). Table 25 lists pedestrian and streetscape capital projects which were approved for funding from the SA in the FY 2014 budget.

Table 25 - FY 14 Successor Agency CIP - Bicycle, Pedestrian and Streetscape Projects

\begin{tabular}{|c|c|c|c|c|c|}
\hline Project Title & Funding Sources & \multicolumn{2}{|c|}{ FY 13 Actuals } & \multicolumn{2}{|c|}{ FY 14 Adopted } \\
\hline Atlantic Avenue Medians between 52nd and Aloha & Redevelopment Bonds & $\$$ & - & $\$$ & $1,735,000$ \\
\hline Atlantic Avenue Medians between 52nd and Aloha & Redevelopment Bonds & $\$$ & - & $\$$ & $2,210,000$ \\
\hline Pine Avenue Streetscape & Other funding & $\$$ & 427,576 & $\$$ & $4,310,000$ \\
\hline & Totals & $\$$ & 427,576 & $\$$ & $8,255,000$ \\
\hline
\end{tabular}

Note: Adapted from City of Long Beach, 2013

\subsubsection{County Funding Sources}

- Proposition C/Transportation Fund. Prop C is a LA County $\$ 0.005$ sales tax measure intended for construction, maintenance and improvement of mass transit services and facilities, or bikeways and streets improvements (City of Long Beach, 2013).

- Measure R. Measure R is a LA County $\$ 0.005$ sales tax measure to fund transportation projects (City of Long Beach, 2013).

All other funding sources listed on the FY 13 and FY 14 Capital Projects in Table 25 are state or federal sources. 


\subsubsection{Minneapolis, Minnesota}

Key Local Funding Sources: Net Debt Bonds

For cities with the population size greater than 300,000 , Minneapolis, MN was one of four cities to receive seven out of a total possible twelve points (see Table 26 below). Minneapolis ranked highly for having many important policy documents in place, a plan funding component, good walking and transit commuter modal share, and Safe Routes to School programming in Elementary schools. It could improve its score by providing a complete streets plan, improving its commuter share of pedestrians, adding Safe Routes to School programming to its middle schools, and expanding the availability of arterial streets with bike lanes. Minneapolis is ranked by the League of American Bicyclists as a Gold Community, and it is considered a Gold Level Walk Friendly Community by the Pedestrian and Bicycle Info Center.

\section{Table 26 - Minneapolis, MN Score}

\begin{tabular}{|l|l|}
\hline City Data & Receive one point \\
\hline Bicycle Master plan & $\mathrm{Y}$ \\
\hline Pedestrian Master plan & $\mathrm{Y}$ \\
\hline Pedestrian and Bicycle Plan & $\mathrm{N}$ \\
\hline $\begin{array}{l}\text { Pedestrian/Bicycle Planning Language in } \\
\text { Comprehensive Plan/Transportation Plan }\end{array}$ & $\mathrm{Y}$ \\
\hline Complete Streets Plan (Local) & $\mathrm{N}$ \\
\hline Plan Funding Component & $\mathrm{Y}$ \\
\hline$\%$ of Commuter Mode Share - Bicycle & $</=5 \%$ \\
\hline$\%$ Commuter Modal Share - Walking & $>/=5 \%$ \\
\hline$\%$ Commuter Modal Share - Transit & $>/=5 \%$ \\
\hline$\%$ of Elementary Schools offering Bike Education & $>50 \%$ \\
\hline$\%$ of Middle Schools offering Bike Education & $<50 \%$ \\
\hline$\%$ of Arterial Streets with Bike Lanes & $<50 \%$ \\
\hline Total Score & $\mathbf{7}$ points \\
\hline
\end{tabular}

\subsubsection{Population and Demographics}

Minneapolis, Minnesota, has a population of 382,578 and covers a total area of 58.0 acres with a population density of 6,900 and a median age of 31 years. The racial demographics are $63.8 \%$ 
White, 18.6\% Black, 2.0\% American Indian, and 5.6\% Asian (U.S. Census, 2010). Of the total population, $10.5 \%$ classify themselves as Hispanic or Latino (U.S. Census, 2010).

\subsubsection{Policy Implementation}

The City of Minneapolis has a suite of transportation plans called Access Minneapolis. Included in this suite is a Downtown Action Plan, a Citywide Action Plan, Design Guidelines for Streets and Sidewalks, a Pedestrian Master Plan, and a Bicycle Master Plan. The stated purpose of this Action Plan suite is to "identify specific actions that the City and its partner agencies need to take within the next ten years to implement the transportation policies articulated in The Minneapolis Plan" (City of Minneapolis, 2014).

The Bicycle Master Plan cites an increase in bikeway mileage in the city from 2000 to 2009 as contributing to a doubling in the bicycle commute work trips (City of Minneapolis, 2011). Their approach was to use alternative arterial trails as separated bike routes (City of Minneapolis, 2011). The Bicycle Master Plan will be updated to include protected bikeways as an approved facility type (City of Minneapolis, 2014).

The Pedestrian Master Plan cites a lack of comprehensive approach to improving the pedestrian experience (City of Minneapolis, 2009). Streetscape and sidewalk improvement often require developer or property owners' initiative, and lack funding to impact an impact an area in a cohesive and connected manner (City of Minneapolis, 2009). As a result, the Master Plan intends to facilitate best practices which include better pedestrian network connectivity and pedestrian zone design (City of Minneapolis, 2009). As of 2014, The City has also launched a parklet pilot program as a way to "encourage pedestrian engagement with the urban environment" (City of Minneapolis, 2014).

\subsubsection{Local Funding Sources}

The City of Minneapolis general fund comprises $32 \%$ of the citywide budget, and is the general operating fund, but is not earmarked for a specific purpose (City of Minneapolis, 2013). 
The City adopts a CIP to fund infrastructure projects. This is adopted every year for the next five years. The CIP is mainly funded by City issued bonds, which are backed by: future property tax payments, "sewer fees, water fees, parking service fees, sales tax, tax increment, special assessments, and other user fees" (City of Minneapolis, 2013). Capital Project Funds accounts account for financial expenditures and resources associated with Community Planning and Economic Development and the Permanent Improvement Capital Fund " (City of Minneapolis, 2013).

All of the bicycle, pedestrian, and streetscape capital projects listed in the FY 2014 adopted budget (as shown in Table 27 below) were solely funded by Net Debt Bonds (NDB), or a combination of NDB, State, and Federal monies. NDB are "property tax supported bonds issued to finance general infrastructure improvements. Debt service is paid by taxes collected for the annual bond redemption levy" (City of Minneapolis, 2013). These bonds are subject to a legal debt margin of $3.33 \%$ of assessed market value (City of Minneapolis, 2013). The base NDB funding levels have been increase in both the 2012-2016 capital program, and the 2014-2018 capital program with the intent to continue the Infrastructure Acceleration Program, with a greater emphasis on bicycle and pedestrian connections as well as roadway, lighting "and economic development projects that enhance the property tax base" (City of Minneapolis, 2013).

The Bicycle Master Plan lists two additional local funding mechanisms: legacy funding and private/corporate donations (City of Minneapolis, 2014). Legacy funding comes from a sales tax referendum that is meant to improve the outdoor and the arts. Private and corporate donations can be accepted by the City, through the City Council and Mayor, for capital projects (City of Minneapolis, 2014). Neither of these sources is in use in the approved FY 14 budget for bicycle, pedestrian, and streetscape infrastructure.

Looking forward, the Pedestrian Master Plan advocates the exploration of new funding mechanisms such as: public private partnerships, cost sharing programs and special service improvement districts (City of Minneapolis, 2009). 


\begin{tabular}{|c|c|c|c|c|c|c|c|c|c|c|c|c|c|c|}
\hline Project & Project Name & Project Detail & Funding Source & & 2014 & & 2015 & & 2016 & & 2017 & & 2018 & Total \\
\hline \multirow[t]{4}{*}{ BIK20 } & $\begin{array}{l}\text { Hiawatha LRT Trail } \\
\text { Lighting }\end{array}$ & $\begin{array}{l}\text { This project will provide lighting } \\
\text { along the Hiawatha } L R T \text { trail } \\
\text { from } 11 \text { th Ave } S \text { to } 28 \text { th } S t E \text {. }\end{array}$ & & \multicolumn{2}{|c|}{$\$ 1,415,000$} & $\$$ & - & $\$$ & - & $\$$ & - & $\$$ & - & $\$ 1,415,000$ \\
\hline & & & Net Debt Bonds & \multicolumn{2}{|c|}{$\$ 375,000$} & $\$$ & - & $\$$ & - & $\$$ & - & $\$$ & - & $\$ 375,000$ \\
\hline & & & Federal Grants & \multicolumn{2}{|c|}{$\$ 1,040,000$} & $\$$ & - & $\$$ & - & $\$$ & - & $\$$ & - & $\$ 1,040,000$ \\
\hline & & & & & & & & & & \multicolumn{4}{|c|}{ Remaining Funding Needed } & $\$$ \\
\hline \multirow[t]{3}{*}{ BR131 } & $\begin{array}{l}\text { North by Northeast } \\
\text { Bikeway Bridge } \\
\text { Connection }\end{array}$ & & & $\$$ & 50,000 & $\$$ & - & $\$$ & - & $\$$ & - & $\$$ & - & 50,000 \\
\hline & & & Net Debt Bonds & $\$$ & 50,000 & $\$$ & - & $\$$ & - & $\$$ & - & $\$$ & - & 50,000 \\
\hline & & & & & & & & & & \multicolumn{4}{|c|}{ Remaining Funding Needed } & $\$$ \\
\hline \multirow[t]{5}{*}{ PV072 } & $\begin{array}{l}\text { Pedestrian } \\
\text { Improvement Project }\end{array}$ & $\begin{array}{l}\text { Addition of pedestrian } \\
\text { improvements to } 6 \text { th, } 7 \text { th, 8th } \\
\text { and 9th Streets. }\end{array}$ & & $\$$ & - & $\$$ & - & & $1,820,000$ & $\$$ & 700,000 & \multicolumn{2}{|l|}{$\$$} & $\$ 2,520,000$ \\
\hline & & & Net Debt Bonds & $\$$ & - & $\$$ & - & $\$$ & 200,000 & $\$$ & 200,000 & & & 5400,000 \\
\hline & & & Municipal State Aid & $\$$ & - & $\$$ & - & $\$$ & 500,000 & $\$$ & 500,000 & $\$$ & - & $\$ 1,000,000$ \\
\hline & & & Federal Grants & $\$$ & - & $\$$ & - & & $1,120,000$ & $\$$ & - & $\$$ & - & $\$ 1,120,000$ \\
\hline & & & & & & & & & & \multicolumn{4}{|c|}{ Remaining Funding Needed } & \multirow{2}{*}{$\begin{array}{l}\$ \quad- \\
\$ \quad 300,000\end{array}$} \\
\hline \multirow[t]{3}{*}{ PV097 } & 18th Ave NE Trail Gap & $\begin{array}{l}\text { Complete existing trail from 6th } \\
\text { St NE to Washington St NE. }\end{array}$ & & $\$$ & - & $\$$ & - & $\$$ & - & $\$$ & - & $\$$ & 300,000 & \\
\hline & & & Net Debt Bonds & $\$$ & - & $\$$ & - & $\$$ & - & $\$$ & - & $\$$ & 300,000 & $\$ 300,000$ \\
\hline & & & & & & & & \multicolumn{6}{|c|}{ Remaining Funding Needed } & \\
\hline PV098 & $\begin{array}{l}\text { Hiawatha Trail Gap (28th } \\
\text { to 32nd St E) }\end{array}$ & $\begin{array}{l}\text { Extend existing trail to fill gap } \\
\text { along LRT/Hiawatha Corridor. }\end{array}$ & & $\$$ & - & $\$$ & - & $\$$ & - & $\$$ & - & $\$$ & 500,000 & 500,000 \\
\hline & & & Net Debt Bonds & $\$$ & - & $\$$ & - & $\$$ & - & $\$$ & - & $\$$ & 500,000 & 500,000 \\
\hline & & & & & & & & & & & naining Fur & ndin & g Needed & $\$$ \\
\hline PV099 & $\begin{array}{l}\text { 26th \& 28th St Buffered } \\
\text { Bike Lanes (Hia to } 35 \mathrm{~W} \text { ) }\end{array}$ & $\begin{array}{l}\text { Add buffered bike lanes in } \\
\text { coordination with mill \& overlay } \\
\text { project. }\end{array}$ & & $\$$ & 200,000 & & 200,000 & $\$$ & - & $\$$ & - & $\$$ & - & 400,000 \\
\hline & & & Net Debt Bonds & $\$$ & 200,000 & & 200,000 & $\$$ & - & $\$$ & - & $\$$ & - & 400,000 \\
\hline & & & & & & & & & & & naining Fur & ndin & g Needed & $\$$ \\
\hline PV100 & $\begin{array}{l}\text { Dinkytown Greenway } \\
\text { Connection (15th } \\
\text { Ave/4th St SE) }\end{array}$ & $\begin{array}{l}\text { Construct new } \\
\text { pedestrian/bicycle access from } \\
\text { existing trail to street level at } \\
\text { 15th Ave SE/4th St SE }\end{array}$ & & $\$$ & 275,000 & $\$$ & - & $\$$ & - & $\$$ & - & $\$$ & - & 275,000 \\
\hline & & & Net Debt Bonds & $\$$ & 275,000 & $\$$ & - & $\$$ & - & $\$$ & - & $\$$ & - & 275,000 \\
\hline & & & & & & & & & & & naining Fur & ndin & g Needed & $\$$ \\
\hline PV101 & $\begin{array}{l}\text { 29th St W Pedestrian } \\
\text { Connection }\end{array}$ & $\begin{array}{l}\text { Construct new pedestrian } \\
\text { connection on the N side of 29th } \\
\text { St W from Dupont Ave S to } \\
\text { Lyndale Ave S }\end{array}$ & & $\$$ & 350,000 & & 350,000 & $\$$ & - & $\$$ & - & $\$$ & - & 700,000 \\
\hline & & & Net Debt Bonds & $\$$ & 350,000 & & 350,000 & $\$$ & - & $\$$ & - & $\$$ & - & 700,000 \\
\hline & & & & & & & & & & & naining Fur & ndin & g Needed & $\$$ \\
\hline TR024 & $\begin{array}{l}\text { Pedestrian Level } \\
\text { Lighting Program }\end{array}$ & $\begin{array}{l}\text { Construct pedestrian level } \\
\text { lighting on various pedestrian } \\
\text { corridors throughout the City. }\end{array}$ & & $\$$ & 500,000 & $\$$ & 500,000 & $\$$ & 500,000 & $\$$ & 500,000 & $\$$ & 500,000 & $\$ 2,500,000$ \\
\hline & & & Net Debt Bonds & $\$$ & 500,000 & & 500,000 & $\$$ & 500,000 & $\$$ & 500,000 & $\$$ & 500,000 & $\$ 2,500,000$ \\
\hline & & & & & & & & & & & naining Fur & ndin & g Needed & $\$$ \\
\hline
\end{tabular}

Note: Adopted from City of Minneapolis, 2013

\subsubsection{San Francisco, California}

\section{Key Local Funding Sources: General Fund, Local Bond, Sales Tax Measure}

For cities with the population size greater than 300,000 , San Francisco, CA was one of four cities to receive seven out of a total possible twelve points (see Table 28 below). San Francisco ranked highly for having an excellent coverage of policy documents, a plan funding component, and a good walking and transit commuter modal share. It could improve its score by increasing its bicycle commuter mode share, increasing the number of elementary and middle schools offering 
Safe Routes to School programming, and increasing the number of arterial streets with bike lanes. San Francisco is ranked by the League of American Bicyclists as a Gold Community, and it is considered a Gold Level Walk Friendly Community by the Pedestrian and Bicycle Info Center.

\section{Table 28 - San Francisco, CA Score}

\begin{tabular}{|l|l|}
\hline City Data & Receive one point \\
\hline Bicycle Master plan & $\mathrm{Y}$ \\
\hline Pedestrian Master plan & $\mathrm{Y}$ \\
\hline Pedestrian and Bicycle Plan & $\mathrm{N}$ \\
\hline $\begin{array}{l}\text { Pedestrian/Bicycle Planning Language in } \\
\text { Comprehensive Plan/Transportation Plan }\end{array}$ & $\mathrm{Y}$ \\
\hline Complete Streets Plan (Local) & $\mathrm{Y}$ \\
\hline Plan Funding Component & $\mathrm{Y}$ \\
\hline$\%$ of Commuter Mode Share - Bicycle & $</=5 \%$ \\
\hline$\%$ Commuter Modal Share - Walking & $>/=5 \%$ \\
\hline \% Commuter Modal Share - Transit & $>/=5 \%$ \\
\hline$\%$ of Elementary Schools offering Bike Education & $<50 \%$ \\
\hline$\%$ of Middle Schools offering Bike Education & $<50 \%$ \\
\hline$\%$ of Arterial Streets with Bike Lanes & $<50 \%$ \\
\hline Total Score & $\mathbf{7}$ points \\
\hline
\end{tabular}

\subsubsection{Population and Demographics}

San Francisco, California, has a population of 805,235 and covers a total area of 46.9 acres with a population density of 17,179 and a median age of 39 years. The racial demographics are $48.5 \%$ White, 6.1\% Black, 0.5\% American Indian, 33.3\% Asian, and 0.4\% Native Hawaiian (U.S. Census, 2010). Of the total population, $15.1 \%$ classify themselves as Hispanic or Latino (U.S. Census, 2010).

\subsubsection{Policy Implementation}

The City of San Francisco has numerous policy documents in place to enhance the bicycle and pedestrian experience in the City:

- General Plan: Transportation Element. The transportation element contains the assumption that "a balance must be restored to the city's transportation system, and various methods must be used to control and shape the impact of automobiles on the 
city. These include improving and promoting public transit, ridesharing, bicycling and walking as alternatives to the single-occupant automobile" (City of San Francisco, 2014). The transportation element includes extensive goals and policies that support improved and prioritized bicycle and pedestrian access and safety throughout the city (City of San Francisco, 2014). The general plan does not contain funding sources or suggestions. However, the implementing plans, such as the bicycle plan, do contain funding information.

- Complete Streets. San Francisco Charter, Article VIIIA, Sec.8A.115: The Municipal Transportation Agency Transit-First Policy is the implementation policy for Complete Streets in the City of San Francisco (City of San Francisco, 2007).

- Bicycle Plan. The 2013 San Francisco Municipal Transportation Agency (SFMTA) Bicycle Strategy replaced the 2009 Bicycle Plan. The new plan has a strategic aim to create a safer transportation experience, make alternative modes the preferred means of travel, and improve the quality of life in San Francisco (San Francisco Municipal Transportation Agency, 2013).

- Streetscapes through Parklets. The City and County of San Francisco published a Parklet manual to guide citizens and businesses in the creation of public streetscape areas that enhance the pedestrian experience (City of San Francisco, 2013). The Project Sponsor is responsible for the cost, and the City and County are responsible for permitting and inspection. Parklet renewals are required annually (City of San Francisco, 2013).

- Pedestrian/Streets Guide. The Better Streets Plan took effect January 16, 2011. This plan includes guidance for streetscape design, pedestrian safety, street ecology, universal design and accessibility, creative use of parking lane, traffic calming, space for public life, and extensive greening.

- Pedestrian. The San Francisco WalkFirst initiative kicked off on March 6, 2014. The programs has "combined public engagement with technical and statistical analysis of where and why pedestrian collisions occur on our city streets, and updated knowledge about the effectiveness and costs of various engineering measures proven to reduce pedestrian collisions," resulting in a "roadmap of urgently needed pedestrian safety projects and programs" to be tackled over the next five years. (City of San Francisco, 2014). 


\section{Local Funding Sources}

The City and County of San Francisco general fund is a "pay-as-you-go" program. The general fund first ensures funding of routine maintenance, ADA transition plans for facilities and public right-of-way (ROW), street resurfacing, and critical project development (City and County of San Francisco, 2013). Remaining funds are allocated towards facilities and streets based on proportionate need (City and County of San Francisco, 2013). The City and County 2014-2023 Capital Plan also identifies "committing a fixed amount of general fund dollars each year to fund pedestrian, bike, and streetscape improvements" as a key general fund policy (City and County of San Francisco, 2013). In 2012, the Ten-Year Capital Plan for the general fund was changed to include the Transportation and Streets Infrastructure Package (TSIP). This was meant to "address a number of improvements that the City has been wrestling with for several years, including: fully funding street repaving to reach and maintain a Pavement Condition Index (PCl) of 70 , which is in the "good" category; addressing long-term municipal railway (Muni) state-of-goodrepair and mid-life fleet overhauls; and investing in safe and complete streets for autos, bikes, pedestrians, and transit vehicles. This set of recommendations ties annual capital needs to ongoing revenue sources, and major enhancement projects to one-time bond funding, including a new vehicle license fee (City and County of San Francisco, 2013). These would be additional transportation funding packages revenues from fixed general fund annual allocations, which are "largely funded through a Vehicle License Fee (VLF) and a Streets \& Transportation General Obligation Bond (G.O.) bond" (City and County of San Francisco, 2013). The Streets \& Transportation G.O. (Measure A) passed with $71.3 \%$ of votes, and the new vehicle license fee (Measure B) passed with $61.23 \%$ of votes (City and County of San Francisco, 2014). Since these measures are newly approved, their effects cannot be reviewed in the timeline of this thesis.

2011 Road Resurfacing \& Street Safety Bond, which was passed by voters in November 2011, allows the City to issue up to $\$ 248$ million in bonds to fund street and right-of-way improvements (City and County of San Francisco, 2013). Streetscape, pedestrian and bicycle safety improvements received a $\$ 50$ million obligation from that total bond (City and County of San Francisco, 2013). 
Proposition $\mathrm{K}$ is a half-cent sales tax approved in 2003 , with 30 year span. It is administered by San Francisco County Transit Authority, and provides $\$ 56$ million for bicycle circulation and safety. "Bicycle projects and programs also could be eligible for funding from the following expenditure plan categories: BART Station Access, Safety and Capacity; New and Upgraded Streets; New Signals and Signs; Advanced Technology and Information Systems; (Maintenance of) Signals and Signs; Traffic Calming; Transportation demand Management/Parking Management; and Transportation/Land Use Coordination (City and County of San Francisco, 2013)."

\subsubsection{Proposed Local Funding Sources}

Throughout their policy and planning documents, the City and County of San Francisco have a number of suggested local funding sources that should be investigated in the future. The items on the list highlighted in bold text are documented as active approaches:

- Neighborhood Impact Fees

- Joint Development Projects

- Synergies among capital street improvement projects

- Public/private partnerships

- Developer requirements

- Development Impact Fees

- Bond measures

\subsubsection{Washington, District of Columbia}

Key Local Funding Sources: General Obligation Bonds, Paygo, and Local Transportation

\section{Revenues}

For cities with the population size greater than 300,000 , Washington, D.C. was one of four cities to receive seven out of a total possible twelve points (see Table 29 below). Washington D.C. ranked highly for having an excellent coverage of policy documents, a plan funding component, and a good walking and transit commuter modal share. It could improve its score by increasing its bicycle commuter mode share, increasing the number of elementary and middle schools offering Safe Routes to School programming, and increasing the number of arterial streets with bike lanes. Washington D.C. is ranked by the League of American Bicyclists as a Silver Community, 
and it is considered a Gold Level Walk Friendly Community by the Pedestrian and Bicycle Info Center.

Table 29 - Washington, D.C. Score

\begin{tabular}{|l|l|}
\hline City Data & Receive one point \\
\hline Bicycle Master plan & $\mathrm{Y}$ \\
\hline Pedestrian Master plan & $\mathrm{Y}$ \\
\hline Pedestrian and Bicycle Plan & $\mathrm{N}$ \\
\hline $\begin{array}{l}\text { Pedestrian/Bicycle Planning Language in } \\
\text { Comprehensive Plan/Transportation Plan }\end{array}$ & $\mathrm{Y}$ \\
\hline Complete Streets Plan (Local) & $\mathrm{Y}$ \\
\hline Plan Funding Component & $\mathrm{Y}$ \\
\hline$\%$ of Commuter Mode Share - Bicycle & $</=5 \%$ \\
\hline$\%$ Commuter Modal Share - Walking & $>/=5 \%$ \\
\hline$\%$ Commuter Modal Share - Transit & $>/=5 \%$ \\
\hline$\%$ of Elementary Schools offering Bike Education & $<50 \%$ \\
\hline$\%$ of Middle Schools offering Bike Education & $<50 \%$ \\
\hline$\%$ of Arterial Streets with Bike Lanes & $<50 \%$ \\
\hline Total Score & 7 points \\
\hline
\end{tabular}

\subsubsection{Population and Demographics}

Washington, D.C., has a population of 601,723 and covers a total area of 68.0 acres with a population density of 9,830 , and a median age of 34 years. The racial demographics are $38.5 \%$ White, 50.7\% Black, 0.3\% American Indian, 3.5\% Asian, and 0.1\% Native Hawaiian (U.S. Census, 2010). Of the total population, 9.1\% classify themselves as Hispanic or Latino (U.S. Census, 2010).

\subsubsection{Policy Implementation}

- Comprehensive Plan - Transportation Element. The transportation element of the District's comprehensive plan identifies the need to increase bicycle and pedestrian connections, routes and facilities as a critical issue facing the District of Columbia (District of Columbia, 2012). This element also seeks to support major action projects identified in 
the 2030 Transportation Vision Plan, which include multimodal centers, pedestrian node improvements, and a bicycle network expansion (District of Columbia, 2012).

- Center City Action Agenda 2008. This is an extensive redevelopment plan for downtown neighborhoods in the District of Washington D.C. The agenda advocates public and private development investment to generate expanded district revenues. Related recommended actions described in the Agenda include (District of Columbia, 2008):

- Bicycling as transportation - Continue to invest in the necessary infrastructure, route definition on city streets, and trail development off-road, to support convenient and safe bicycling conditions.

- Walking as transportation - Aggressively enforce district regulations and public space standards to ensure that walkability and pedestrian experience are protected and enhanced and that investment in corridor upgrades address traffic function and calming, and retail development

- Bicycle Plan. The 2005 Bicycle Master Plan identifies three major milestones for measuring long-term progress (District of Columbia, 2005):

- 50 miles of DC Streets will have better Bicycle Level of Service by 2010 and 100 miles will have better Bicycle LOS ratings by 2015.

- Proportion of bicycle trips will increase from $1 \%$ in 2000 to $3 \%$ in 2010 , and to $5 \%$ by 2015 .

- The rate of bicycle collisions with motor vehicles will reduce from 26 reported bike crashes per 1 million bike trips in 2000 to 20 per 1 million in 2010 , and to 15 per 1 million in 2020.

- The master plan also identifies annual physical improvements and program recommendations with cost estimates.

- Pedestrian Plan. The Pedestrian Master Plan vision states that, "Washington, DC will be a city where any trip can be taken on foot safely and comfortably, and where roadways equally serve pedestrians, bicyclists, transit users and motorists (District of Columbia, 
2009)." The Pedestrian Master Plan identified eight priority pedestrian corridors, where poor conditions for walking exist in locations with high levels of pedestrian activity (District of Columbia, 2009). The Master Plan also identifies performance measures, physical improvements and policies with cost estimates.

- Great Streets. The Great Streets program is a "multi-year, multi-agency commercial revitalization initiative to transform emerging corridors into thriving and inviting neighborhood centers" (District of Columbia, n.d.). This initiative includes capital infrastructure projects that improve corridors through "streetscape design elements, including improvements to sidewalks, curbs, gutters, streets, tree boxes, replace street trees and install other streetscape elements" (District of Columbia, 2913). Among other objectives, project construction is intended to provide bicycle lanes and improve pedestrian circulation.

\subsubsection{Local Funding Sources}

The District of Columbia funds bicycle and pedestrian infrastructure through a combination of General Obligation Bonds, Paygo, and Local Transportation Revenues.

General Obligation Bonds (GO Bonds) are "sold by [the] municipal government to private investors to provide long-term financing for capital project needs. Repayment of the principal and interest is made from General Fund revenue" (District of Columbia, 2013).

Paygo, or pay-as-you-go, financing is a payment in lieu of taxes from the developer for the new headquarters for the U.S. Department of Transportation (US DOT) (District of Columbia, 2013).

Local Transportation Revenues are generated from a portion of ROW occupancy fees, public inconvenience fees, and utility marking fees (District of Columbia, 2013).

Major future investment in bicycle and pedestrian capital projects is structured under the Great Streets projects, the Kennedy Street Streetscapes, and the Rhode Island Avenue NE Small Area Plan. These are estimated to receive $\$ 43,328,000$ in funding over the 6 year period from FY 2014 to FY 2019 (District of Columbia, 2013). An estimated $\$ 31$ million of those Great Streets projects 
will be funded by the PAYGO program (District of Columbia, 2013). Proposed local funding is broken down as follows (District of Columbia, 2013), and as shown using relevant proposed fund figures in Table 30 below:

- Great Streets Initiative Infrastructure - Proposed $\$ 31,040,000$ local funding from Paygo.

- Pedestrian \& Bicycle Enhancements - Proposed \$5,967,000 from GO Bonds, $\$ 2,133,000$ from Paygo, \$1,054,000 from Local Transportation Revenue.

- Kennedy Street Streetscapes - Proposed \$3,000,000 from GO Bonds in FY 2014.

- Rhode Island Avenue NE Small Area Plan Streetscape Improvements - Proposed \$2,000,000 from GO Bonds in FY 2014.

Table 30 - District of Columbia Bicycle and Pedestrian Capital Projects - Proposed Local Funding

\begin{tabular}{|c|c|c|c|c|c|c|c|}
\hline Local Funding Sources & FY 2014 & FY 2015 & FY 2016 & FY 2017 & FY 2018 & FY 2019 & 6 Yr. Total \\
\hline Pay Go & $5,108,000$ & $5,228,000$ & $6,049,000$ & $6,824,000$ & $6,824,000$ & $5,624,000$ & $35,657,000$ \\
\hline GO Bonds & $5,000,000$ & 908,000 & 925,000 & 150,000 & 150,000 & - & $7,133,000$ \\
\hline $\begin{array}{l}\text { Local Transportation } \\
\text { Revenue }\end{array}$ & 904,000 & - & - & - & - & 150,000 & $1,054,000$ \\
\hline & & & & & & & $43,844,000$ \\
\hline
\end{tabular}

Note: Adopted from District of Columbia, 2013

\subsubsection{Proposed Local Funding Sources}

The transportation plan includes suggested roadway pricing approaches, such as cordon pricing, to charge for "wear-and-tear on the roadway system, air and noise pollution, imposition of congestion, etc." (District of Columbia, 2012). This roadway pricing approach includes policy action T-3.1.B, which calls for the implementation of a roadway pricing technique by 2030 (District of Columbia, 2012). Whether or not roadway pricing revenues are expected to be distributed to multimodal infrastructure is not addressed in the planning document. 


\section{Case Study Findings}

\subsection{Small City Findings - Population 1,000 to 49,999}

Three of the cities selected for further evaluation in a case study fell into the smallest population group of 1,000 to 49,999 . These cities were evaluated based on their level of commitment to facilities, financing, and planning. These cities stood out for their implemented policy, budget measures, existing modal share, Safe Routes to School Programming, and/or percentage of arterial streets with bicycle lanes.

Analysis of these cities found common priorities for identified bicycle and pedestrian capital expenditures. These were the need to complete bicycle and pedestrian networks, and the need to add corner ramps to make existing sidewalk networks ADA accessible. Secondary projects included streetscape plans and trail networks.

While all cities were receiving federal and state funding for infrastructure projects, they also identified funding shortfalls, and the need to find additional creative local funding approaches. One of the surprising results of this case study analysis, as illustrated in Table 1, was that only two of the three small cities had one local funding mechanism in common. This commonality was the use of bond issues to fund bicycle and pedestrian capital projects.

Table 31 - Small City Existing Local Bicycle and Pedestrian Funding Mechanisms

\begin{tabular}{|c|c|c|c|c|c|c|c|c|}
\hline City, STATE & Pop. & $\begin{array}{l}\text { County } \\
\text { Sales } \\
\text { Tax } \\
\text { Measure } \\
\end{array}$ & $\begin{array}{l}\text { General } \\
\text { Fund }\end{array}$ & $\begin{array}{l}\text { Bond } \\
\text { Issue } \\
s \\
\end{array}$ & $\begin{array}{l}\text { Tax } \\
\text { Increment } \\
\text { Financing } \\
\text { District } \\
\end{array}$ & $\begin{array}{l}\text { Marine } \\
\text { Passenger } \\
\text { Fees }\end{array}$ & $\begin{array}{l}\text { Developer } \\
\text { In-Lieu } \\
\text { Fees }\end{array}$ & $\begin{array}{l}\text { Capital } \\
\text { Improve. } \\
\text { Fund } \\
\end{array}$ \\
\hline $\begin{array}{l}\text { Charlottesville, } \\
\text { VA }\end{array}$ & 43,475 & No & Yes & Yes & No & No & No & Yes \\
\hline Juneau, AK & 31,275 & Yes & No & No & No & Yes & Yes & No \\
\hline $\begin{array}{l}\text { Shorewood, } \\
\text { WI }\end{array}$ & 13,162 & No & No & Yes & Yes & No & No & No \\
\hline \multicolumn{2}{|l|}{ Totals } & 1 & 1 & 2 & 1 & 1 & 1 & 1 \\
\hline
\end{tabular}

This suggests that for small cities, local funding sources are unique to the needs of city and region. It also suggests that smaller cities may have more flexibility to adapt policy to their needs. 


\subsection{Trends}

This case study analysis of eleven cities across the U.S. proved cities with extensive planning, policy, Safe Routes to School programming and higher than normal bicycle and pedestrian modal shares still struggle to find funding for their bicycle and pedestrian capital projects. Without heavily augmenting state and federal funding sources with local sources, many projects languish. Review of each city's CIP revealed extensive bicycle and pedestrian infrastructure projects that requested funding but did not end up on the final budget due to lack of available funding. Or, many other projects in the CIP included a note that projects had submitted requests for federal and/or state funding and were awaiting results.

Analysis of all eleven cities found common priorities similar to those identified for the smaller cities. These priorities included the need to complete bicycle and pedestrian networks, and the need to add corner ramps to make existing sidewalk networks ADA accessible. Secondary priorities, however, varied greatly. Bicycle and pedestrian projects in the two larger population categories benefited from connection to large inter-city or regional transit projects. All cities with a population larger than 50,000 were also concerned with solving issues of livability and congestion management by improving bicycle and pedestrian networks and environments.

Review of the eleven case study cities revealed a heavy reliance on local financing mechanisms to implement bicycle and pedestrian infrastructure projects. According to population grouping, as shown in Table 32, the most popular local funding mechanisms are:

- $\quad 1,000-49,999$ - Bond Issues (used by 2 of 3 cities)

- 50,000 - 99,999 - County Sales Tax Measure (used by both cities)

- $\quad$ 100,000 - 299,999 - General Fund and Transportation Impact Fees (used by both cities)

- $\quad>300,000$-Bond Issues (used by 3 of 4 cities) 
Table 32 - Existing Local Bicycle and Pedestrian Funding Mechanisms by Population Group

\begin{tabular}{|l|l|l|l|l|}
\hline Population size & $\begin{array}{l}\mathbf{1 , 0 0 0}- \\
\mathbf{4 9 , 9 9 9}\end{array}$ & $\begin{array}{l}\mathbf{5 0 , 0 0 0}- \\
\mathbf{9 9 , 9 9 9}\end{array}$ & $\begin{array}{l}\mathbf{1 0 0 , 0 0 0}- \\
\mathbf{2 9 9 , 9 9 9}\end{array}$ & $\mathbf{3 0 0 , 0 0 0}$ \\
\hline \# of Case Study Cities & 3 & 2 & 2 & 4 \\
\hline County Sales Tax Measure & $1 / 3$ & $\mathbf{2} / \mathbf{2}$ & $1 / 2$ & $\mathbf{2}$ \\
\hline General Fund & $\mathbf{2 / 3}$ & $0 / 2$ & $\mathbf{2} / \mathbf{2}$ & $1 / 4$ \\
\hline Transportation Impact Fees & $0 / 3$ & $1 / 2$ & $\mathbf{2} / \mathbf{2}$ & $1 / 4$ \\
\hline Bond Issues & $\mathbf{2 / 3}$ & $0 / 2$ & $0 / 2$ & $\mathbf{3} / 4$ \\
\hline $\begin{array}{l}\text { Tax Increment Financing } \\
\text { District }\end{array}$ & $1 / 3$ & $0 / 2$ & $1 / 2$ & $0 / 4$ \\
\hline Developer Agreements & $0 / 3$ & $1 / 2$ & $0 / 2$ & $0 / 4$ \\
\hline Utility User Tax & $1 / 3$ & $1 / 2$ & $0 / 2$ & $0 / 4$ \\
\hline Marine Passenger Fees & $1 / 3$ & $0 / 0$ & $0 / 2$ & $0 / 4$ \\
\hline Developer In-Lieu Fees & $1 / 3$ & $0 / 0$ & $0 / 2$ & $1 / 4$ \\
\hline Re-development Agency & $0 / 3$ & $0 / 0$ & $0 / 2$ & $1 / 4$ \\
\hline Capital Improvement Fund & $1 / 3$ & $0 / 0$ & $0 / 2$ & $0 / 4$ \\
\hline $\begin{array}{l}\text { Local Transportation } \\
\text { Revenues }\end{array}$ & $0 / 3$ & $0 / 0$ & $0 / 2$ & $1 / 4$ \\
\hline
\end{tabular}

A review of the most widely used local funding mechanisms across all eleven case study cities (as shown in Table 33 below) revealed that reliance on funding from a county sales tax measure was the most popular mechanism - used by six out of eleven cities studied. Bond issues were the second most widely used approach, used by five out of eleven cities. General fund allocations and transportation impact fees followed as the third most widely employed funding methods used by four out of eleven cities studied.

The total list also shows a wide variance of approaches available to cities of all size for local funding methods. From the study of eleven cities there were twelve different existing local funding mechanisms in use. 
Table 33 - Existing Local Bicycle and Pedestrian Funding Mechanisms by Local Funding Mechanism

\begin{tabular}{|c|c|c|c|c|c|c|c|c|c|c|c|c|c|}
\hline City, STATE & Population & $\begin{array}{l}\text { County } \\
\text { Sales } \\
\text { Tax } \\
\text { Measure }\end{array}$ & $\begin{array}{l}\text { Bond } \\
\text { Issues }\end{array}$ & $\begin{array}{l}\text { General } \\
\text { Fund }\end{array}$ & $\begin{array}{l}\text { Transportation } \\
\text { Impact Fees }\end{array}$ & $\begin{array}{l}\text { Tax } \\
\text { Increment } \\
\text { Financing } \\
\text { District }\end{array}$ & $\begin{array}{l}\text { Developer } \\
\text { In-Lieu } \\
\text { Fees }\end{array}$ & $\begin{array}{l}\text { Developer } \\
\text { Agreements }\end{array}$ & $\begin{array}{l}\text { Utility } \\
\text { User } \\
\text { Tax }\end{array}$ & $\begin{array}{l}\text { Marine } \\
\text { Passenger } \\
\text { Fees }\end{array}$ & $\begin{array}{l}\text { Re- } \\
\text { development } \\
\text { Agency }\end{array}$ & $\begin{array}{l}\text { Capital } \\
\text { Improvement } \\
\text { Fund }\end{array}$ & $\begin{array}{l}\text { Local } \\
\text { Transportation } \\
\text { Revenues }\end{array}$ \\
\hline $\begin{array}{l}\text { Charlottesville, } \\
\text { VA }\end{array}$ & 43,475 & No & Yes & Yes & No & No & No & No & No & No & No & Yes & No \\
\hline Juneau, AK & 31,275 & Yes & No & No & No & No & Yes & No & No & Yes & No & No & No \\
\hline Shorewood, WI & 13,162 & No & Yes & No & No & Yes & No & No & No & No & No & No & No \\
\hline $\begin{array}{l}\text { Santa Barbara, } \\
\text { CA }\end{array}$ & 88,410 & Yes & No & No & No & No & No & No & Yes & No & No & No & No \\
\hline $\begin{array}{l}\text { Santa Monica, } \\
\text { CA }\end{array}$ & 89,736 & Yes & No & No & Yes & No & No & Yes & No & No & No & No & No \\
\hline Fort Collins, CO & 143,986 & Yes & No & Yes & Yes & No & No & No & No & No & No & No & No \\
\hline Gainesville, FL & 124,354 & No & No & Yes & Yes & Yes & No & No & No & No & No & No & No \\
\hline Long Beach, CA & 462,257 & Yes & No & No & Yes & No & No & No & No & No & Yes & No & No \\
\hline Minneapolis, MN & 382,578 & No & Yes & No & No & No & No & No & No & No & No & No & No \\
\hline $\begin{array}{l}\text { San Francisco, } \\
\text { CA }\end{array}$ & 805,235 & Yes & Yes & Yes & No & No & No & No & No & No & No & No & No \\
\hline Washington, DC & 601,723 & No & Yes & No & No & No & Yes & No & No & No & No & No & Yes \\
\hline \multicolumn{2}{|l|}{ Totals } & 6 & 5 & 4 & 4 & 2 & 2 & 1 & 1 & 1 & 1 & 1 & 1 \\
\hline
\end{tabular}

7.3. Opportunities

In addition to local funding mechanisms used by the eleven case study cities, creative mechanisms were cited by these case study cities as possible future approaches.

Possible future funding mechanisms listed by case study cities included:

- Cost sharing programs

- Joint Development Projects 
- Neighborhood Impact Fees

- $\quad$ Private Funding

- Public/private partnerships

- Special service improvement districts

- Synergies among capital street improvement projects

- Cordon/congestion pricing

\subsection{Conclusions}

The analysis of eleven different sized case study cities across the United States revealed that cities are sharing common infrastructure needs and funding shortfalls. While the case study analysis did not find a common funding factor across all eleven cities, it did illustrate that for the case study cities, voter approved measures such as county sales tax measures and bond issues are the most heavily relied upon approaches to local source funding bicycle and pedestrian capital project implementation. It also illustrated that implementation success is not only commensurate with funding, but that it requires the backing of intention in the form of planning and policy documents. Due to the variety in funding approaches, this thesis would recommend a full review of all thirty-six bicycle and pedestrian friendly communities to determine if case study trends towards the use of sales tax measures and bond issues remain constant a larger grouping. This expanded study would also help identify additional trends for some of the lesser used funding approaches found amongst these eleven case study cities. 


\section{Additional Conclusions, Recommendations and Further Study}

\subsection{Voter Approved Funding}

The fact that voters are willing to approve local funding mechanisms for transportation illustrates a growing public awareness of the funding gap faced in their cities and counties. It also illustrates a willingness by the public to pay more for congestion relief, improved roadway surfaces and multi-modal transportation options to improve quality of life. On November 4,2104 , " $72 \%$ of all transit or multi-modal measures were approved this year, including [November $4^{\text {th }}$ ] results similar to the trend of recent years (Davis, 2014)." In addition to the two measures passed in San Francisco, other transportation bonds, amendments and measures approved by voters on November 4' 2014, were:

- Alameda County, CA: Sales Tax Measure BB. 30 year transportation expenditure plan. This sales tax measure renewed Measure B, which was approved in 2000, and increased that existing tax by a half-cent, for a combined total of a one cent sales tax ((Alameda County Transportation Commission, n.d.). Plan priorities include improvement to bicycle and pedestrian safety (Alameda County Transportation Commission, n.d.).

- Fairfax County, VA - Transportation Bond Referendum. \$100 million bond which specifies connectivity improvement, capacity improvement and facility development for pedestrians and bicyclists (2014 Fairfax County transportation bond referendum, n.d.).

- Seminole County, FL - One Cent Infrastructure Tax - Sales tax measure whose language includes construction and rehabilitation of bicycle and pedestrian facilities and trails (One Cent Infrastructure Tax, 2014).

\subsection{Recommendations and Further Investigation}

This study could be expanded by soliciting interviews with City staff, which would help develop a fuller picture of the role private funding, and public-private funding, plays in bicycle and pedestrian project development and implementation. While most planning documents reference these as preferred methods, it was difficult to find public documentation that outlined these contributions. It would also be instructive to investigate blanket policy changes that Cities could make to allow them to treat available funding mechanisms as tools available to them to use where suitable. 
Lastly, the reliance on voter approved funding mechanisms suggests the importance of agency and project transparency; strong and consistent communication with the public (including postproject implementation budget reviews and user feedback); and targeted project marketing. Many of the case study cities reviewed that had consistent, long-term support for bicycle and pedestrian projects, also had regular and easy to read reporting, public-focused communication, and ample avenues for feedback. A targeted study that analyzed the key tools and methods used for reporting, transparency and public outreach efforts of cities like Fort Collins, CO, San Francisco, CA and Santa Monica, CA could help other agencies expand their effectiveness with their existing funding mechanisms. 


\section{References}

2014 Fairfax County transportation bond referendum. (n.d.). Retrieved November 26, 2014, from http://www.fairfaxcounty.gov/bond/

akpedbikealliance. (2011, May 4). Juneau receives recognition for being a bicycle and walk friendly community. Retrieved October 25,2014 , from http://akpedbikealliance.wordpress.com/2011/05/04/\%e2\%80\%a2-juneau-receivesrecognition-for-being-a-bicycle-and-walk-friendly-community/

Alameda County Transportation Commission. (n.d.). Measure B : Alameda CTC. Retrieved November 26, 2014, from http://www.alamedactc.org/app_pages/view/4617

Alameda County Transportation Commission. (n.d.). Yes on BB. Retrieved December 10, 2014, from http://www.yesonbb.org/

American Planning Association. (2010). Complete streets : best policy and implementation practices (No. 559). Chicago, IL.

Andersen, M. (2013, October 15). Memphis is about to build the country's first crowdfunded bike lane. Retrieved November 26, 2014, from http://www.peopleforbikes.org/blog/entry/memphis-is-about-to-build-the-countrys-firstcrowdfunded-bike-lane

Andersen, M. (2014, November 10). How Denver got an oil company to help crowdfund a protected bike lane. Retrieved November 26, 2014, from http://www.peopleforbikes.org/blog/entry/how-denver-got-an-oil-company-to-helpcrowdfund-a-protected-bike-lane?utm source=twitterfeed\&utm medium=twitter

Arapahoe Street protected bike lane. (2014). Retrieved November 26, 2014, from https://ioby.org/project/arapahoe-street-protected-bike-lane

City and Borough of Juneau, Alaska. Chapter 69.20, 69.20.005 Marine passenger fee (2000).

City and Borough of Juneau, Alaska. (2004, November 22). Long range waterfront plan for the City and Borough of Juneau. Retrieved October 25, 2014, from http://www.juneau.org/plancomm/Final LRWP 112204.php

City and Borough of Juneau, Alaska. (2005, October 10). Ordinance of the City and Borough of Juneau, Alaska: Serial no. 2005-(am). Retrieved October 25, 2014, from http://www.juneau.org/clerk/Ordinances/Ord2005-29\%28am\%29-Seawalk.pdf

City and Borough of Juneau, Alaska. (2009, November 2). Juneau non-motorized transportation plan. Retrieved October 20, 2014, from http://www.juneau.org/cddftp/documents/JNMTPFinalwithMaps.pdf

City and Borough of Juneau, Alaska. (2013, January 15). Comprehensive annual financial report: Fiscal year July 1, 2011 to June 30, 2012. Retrieved October 20, 2014, from http://www.juneau.org/financeftp/cafr2012/CompleteCAFR.pdf 
City and Borough of Juneau, Alaska. (2014, June 30). CBJ capital improvement program: Fiscal years 2015-2020. Retrieved October 25, 2014, from http://www.juneau.org/engineering/CIP/FINAL/2015-2020.php

City of Austin. (2012). Great street standards. Retrieved November 26, 2014, from http://www.austintexas.gov/sites/default/files/files/Planning/Urban Design/great street si te overview 0512.pdf

City of Austin. (2014). Great Streets. Retrieved November 26, 2014, from http://www.austintexas.gov/page/great-streets

City of Boulder, CO. (2003). Peer city analysis: Fort Collins, Colorado. Retrieved November 1, 2014, from https://bouldercolorado.gov/pages/peer-city-analysis-fort-collins-colorado

City of Charlottesville. (2003). Charlottesville : 2003 bicycle and pedestrian facilities master plan. Retrieved July 19, 2014, from http://www.charlottesville.org/Index.aspx?page=3559

City of Charlottesville. (2013). Charlottesville strategic investment area plan. Retrieved July 21,2014 , from http://www.charlottesville.org/Modules/ShowDocument.aspx?documentid=27996

City of Charlottesville. (2014). Charlottesville: Complete Streets. Retrieved July 31, 2014, from http://www.charlottesville.org/lndex.aspx?page=3573

City of Charlottesville. (2013, August 19). Comprehensive plan. Retrieved December 10, 2014, from http://www.charlottesville.org/index.aspx?page $=3523$

City of Charlottesville. (2013). Operating and capital improvement budget; Adopted; FY 20132014. Retrieved July 19, 2014, from http://www.charlottesville.org/Modules/ShowDocument.aspx?documentid=26280

City of Fort Collins. (2011a, February 15). Pedestrian plan. Retrieved from http://www.fcgov.com/planfortcollins/pdf/ped-plan.pdf

City of Fort Collins. (2011b, February 15). Transportation master plan. Retrieved October 27, 2014 from http://www.fcgov.com/planfortcollins/pdf/tmp.pdf

City of Fort Collins. (2012, December). Appendix F: Capital improvement plan documentation. Retrieved October 27, 2014, from http://www.fcgov.com/planfortcollins/pdf/cip-doc2012.pdf

City of Fort Collins. (2014a, June 2). Street oversizing program summary. Retrieved November 1 , 2014, from http://www.fcgov.com/engineering/pdf/oversizing-summary.pdf

City of Fort Collins. (2014e, June 3). Street oversizing program responsibilities. Retrieved November 1, 2014, from http://www.fcgov.com/engineering/pdf/oversizingresponsibilities.pdf 
City of Fort Collins. (2014b, August 7). Voter approved sales tax initiatives 1973-2021. Retrieved November 1, 2014, from http://www.fcgov.com/bob/pdf/voter-approved-tax-initiatives.pdf

City of Fort Collins. (2014c, August 29). City manager's recommended biennial budget: 2015 2016. Retrieved October 27, 2014, from http://www.fcgov.com/citymanager/pdf/city-manager-recommended-budget-2015-2016web.pdf

City of Fort Collins. (2014d, October 15). Bicycle plan (draft). Retrieved October 27, 2014, from http://www.fcgov.com/bicycling/pdf/draft-bicycle-master-plan_v2.pdf

City of Gainesville. (2002, March 4). Comprehensive plan: Capital improvements data analysis. Retrieved November 2, 2014, from http://www.cityofgainesville.org/portals/0/plan/docs/capitalimp02.pdf

City of Gainesville. (2012, October 1). FY 2013-14 Financial \& Operating Plan. Retrieved November 2, 2014 from http://www.cityofgainesville.org/Portals/0/bf/FY\%202013\%20\%20FY\%202014\%20Adopted\%20Financial\%20Operating\%20Plan_OPT3.pdf

City of Gainesville. (2013a, September 30). 2013 Comprehensive annual financial report. Retrieved November 2, 2014, from http://www.cityofgainesville.org/Portals/0/bf/2013\%20CAFR.pdf

City of Gainesville. (2013b, October 12). Transportation mobility element: Goals, objectives, and policies. Retrieved November 2, 2014, from http://www.cityofgainesville.org/Portals/0/plan/2014\%20Web\%20Update/TRANSPORTAT ION\%20MOBILITY 2Printable.pdf

City of Gainesville. (2013c, November 17). Future land use element: Goals, objectives, and policies. Retrieved November 2, 2014, from http://www.cityofgainesville.org/Portals/0/plan/FUTURE\%20LAND\%20USE\%20ELEMEN T Printable 140826.pdf

City of Gainesville. (2014, November 17). Capital improvements element: Goals, objectives, and policies. Retrieved November 2, 2014, from http://www.cityofgainesville.org/Portals/0/plan/CAPITAL\%20IMPROVEMENTS Printable. pdf

City of Long Beach. (2011). Adopt the principles for active living and complete streets for inclusion in the update to the Long Beach general plan. Retrieved November 2, 2014, from http://www.publichealth.lacounty.gov/place/docs/LongBeach ActiveLivingPrinciples.pdf

City of Long Beach. (2013a, June 2). FY 2014 adopted budget. Retrieved November 2, 2014, from http://www.longbeach.gov/civica/filebank/blobdload.asp?BloblD=37980

City of Long Beach. (2013b, October). General plan: Mobility element. Retrieved November 2, 2014, from http://www.lbds.info/civica/filebank/blobdload.asp?BloblD=4112 
City of Long Beach. (2014, January 21). FY 14 adopted CIP book. Retrieved November 2, 2014, from http://www.longbeach.gov/civica/filebank/blobdload.asp?BloblD=38420

City of Long Beach. (n.d.). Bicycle master plan. Retrieved November 3, 2014, from http://www.longbeach.gov/pw/traffic/projects/bicycle master plan.asp

City of Minneapolis. (2009, October 16). Pedestrian master plan. Retrieved November 3, 2014, from http://www.minneapolismn.gov/pedestrian/projects/pedestrian pedestrian-Master plan

City of Minneapolis. (2011, June). Bicycle master plan. Retrieved November 3, 2014, from http://www.minneapolismn.gov/bicycles/projects/plan

City of Minneapolis. (2013, December 11). 2014 Council adopted budget. Retrieved November 3, 2014, from http://www.minneapolismn.gov/finance/budget/WCMS1P-119069

City of Minneapolis. (2014a, June 5). Protected bikeways. Retrieved November 3, 2014, from http://www.minneapolismn.gov/bicycles/projects/WCMS1P-123828

City of Minneapolis. (2014b, September 30). Minneapolis parklet pilot program. Retrieved November 3, 2014, from http://www.minneapolismn.gov/pedestrian/WCMS1P-130301

City of Minneapolis. (2014c, October 23). ACCESS Minneapolis - City of Minneapolis. Retrieved November 3, 2014, from http://www.minneapolismn.gov/publicworks/transplan/index.htm

City and County of San Francisco. (2013a, April 16). FY2014-23 ten-year capital plan. Retrieved November 4, 2014, from http://onesanfrancisco.org/fy2014-23-ten-year-capital-plan/

City and County of San Francisco. (2013b, July 23). Adopted budget: FY 2013-2014 and 20142015. Retrieved November 4, 2014, from http://sfcontroller.org/modules/showdocument.aspx?documentid=4497

City and County of San Francisco, CA. (2013, May 1). Adopted five-year financial plan: FY 2013/14 through 2017/18. Retrieved November 3, 2014, from http://sfmayor.org/Modules/ShowDocument.aspx?documentID=258

City and County of San Francisco. (2014). Consolidated general election summary report. Retrieved November 26, 2014, from http://sfgov2.org/ftp/uploadedfiles/elections/ElectionsArchives/2014/Nov/Summary6.pdf

City of San Francisco. Transit-first policy, Article VIIIA (2007). Retrieved November 4, 2014, from http://www.amlegal.com/nxt/gateway.dll/California/transportation/transportationcode?f=te mplates $\$$ fn $=$ default.htm $\$ 3.0 \$ v i d=a m l e g a l:$ sanfrancisco ca $\$ a n c=J D$ Transportation

City of San Francisco. (2010, December). Better streets plan. Retrieved November 4, 2014, from http://www.sf-planning.org/ftp/BetterStreets/proposals.htm\#Final Plan 
City of San Francisco. (2013, February). San Francisco parklet manual. Retrieved November 3, 2014, from http://pavementtoparks.sfplanning.org/docs/SF_P2P_Parklet_Manual_1.0_FULL.pdf

City of San Francisco. (2014a, March 6). Walk first. Retrieved November 4, 2014, from http://walkfirst.sfplanning.org/

City of San Francisco. (2014b, March 14). Invest in neighborhoods - 2013 grant awards. Retrieved November 3, 2014, from http://investsf.org/wordpress/wp-content/uploads/2014/03/IIN-2013-NeighborhoodImprovment-Project-Grant-Awards.pdf

City of San Francisco. (2014c, August 14). San Francisco general plan. Retrieved November 4, 2014, from http://www.sf-planning.org/ftp/General_Plan/index.htm

City of Santa Barbara. (2013, March). 2014-2019 capital improvement program. Retrieved October 25, 2014, from http://santabarbaraca.gov/SBdocuments/Advisory Groups/Budget/Adopted/04 SixYear Capital Improvement Program for Fiscal Years 2014 - 2019/0000000000 SixYear CIP - Narrative.pdf

City of Santa Barbara. (2014, June 17). Adopted operating and capital budget for fiscal year 2015. Retrieved October 25, 2014, from http://www.santabarbaraca.gov/SBdocuments/Advisory Groups/Budget/Adopted/02 Ado pted Budget Document for Fiscal Year 2015/0000000000 Adopted Operating and Capital Budget for Fiscal Year 2015.pdf

City of Santa Monica. (2010, July 6). Land use and circulation element. Retrieved October 26, 2014, from http://www.smgov.net/uploadedFiles/Departments/PCD/Plans/General-Plan/Land-Useand-Circulation-Element.pdf

City of Santa Monica. (2011, June). Adopted CIP bienniel budget FY 2014-16. Retrieved from http://www.smgov.net/uploadedFiles/Departments/Finance/Annual Budgets/20132015 Budget/2013-2015 Adopted Budget/Adopted\%20CIP\%20Budget\%20Book\%201416.pdf

City of Santa Monica. (2011, June). FY 2013-15 adopted bienniel budget. Retrieved October 26, 2014, from http://www.smgov.net/uploadedFiles/Departments/Finance/Annual Budgets/20132015 Budget/2013-2015 Adopted Budget/FY2013-15 Adopted Budget.pdf

City of Santa Monica. (2011, November). Santa Monica bike action plan. Retrieved October 26, 2014, from http://www.smgov.net/uploadedFiles/Departments/PCD/Plans/Bike-Action-Plan/BicycleAction-Plan.pdf 
City of Santa Monica. Transportation impact fee program (2013). Retrieved October 26, 2014, from

http://www.smgov.net/departments/Council/agendas/2013/20130312/s2013031207-B$1 . \mathrm{htm}$

Clark, A. (2014, November 4). Transportation tax soundly defeated in Alachua County. Gainesville.com. Retrieved November 4, 2014, from http://www.gainesville.com/article/20141104/ARTICLES/141109836

Complete Streets Act: AB 1358., Pub. L. No. 1358 (2008). Retrieved December 9, 2013, from http://www.leginfo.ca.gov/pub/07-08/bill/asm/ab 13511400/ab 1358 bill 20080930 chaptered.pdf

Cradock, A. L., Troped, P. J., Fields, B., Melly, S. J., Simms, S. V., Gimmler, F., \& Fowler, M. (2009). Factors associated with federal transportation funding for local pedestrian and bicycle programming and facilities. Journal of Public Health Policy, 30, S38-S72. doi:10.1057/jphp.2008.60

Congress for the New Urbanism. (1999). Charter of the New Urbanism. Retrieved November 26, 2014, from http://www.cnu.org/sites/files/charter book.pdf

Congress for the New Urbanism. (2012, January 19). Sustainable street network principles. Retrieved November 26, 2014, from http://www.cnu.org/sites/www.cnu.org/files/sustainable street network principles op.pdf

Coté, M. C. and J. (2013, November 25). Task force: billions needed to fix transit in S.F. SFGate. Retrieved January 12, 2014, from http://www.sfgate.com/bayarea/article/Task-forcebillions-needed-to-fix-transit-in-S-F-5008878.php\#src=fb

Davis, S. L. (2014, November 5). Important transportation ballot measures decided yesterday. Retrieved November 16, 2014, from http://t4america.org/2014/11/05/importanttransportation-ballot-measures-decided-yesterday/

De Zeeuw, D., \& Flusche, D. (2011). How a bill becomes a bike lane: federal legislation, programs, and requirements of bicycling and walking projects. Planning \& Environmental Law, 63(8), 8-11.

District of Columbia. (2005, April). Bicycle master plan. Retrieved December 5, 2014, from http://ddot.dc.gov/sites/default/files/dc/sites/ddot/publication/attachments/bicycle master plan 2005 final document 0 .pdf

District of Columbia. (2008, March 5). Transportation focused resources. Retrieved December 5, 2014, from http://planning.dc.gov/sites/default/files/dc/sites/op/publication/attachments/transportation focused resources ccaa.pdf

District of Columbia. (2009, April). Pedestrian master plan. Retrieved December 5, 2014, from http://ddot.dc.gov/sites/default/files/dc/sites/ddot/publication/attachments/pedestrianmast erplan 2009.pdf

District of Columbia. (2012, March 1). Transportation element. Retrieved December 6, 2014, from http://planning.dc.gov/sites/default/files/dc/sites/op/publication/attachments/vol 1 transpo rtation.pdf 
District of Columbia. (2013, August 8). Annual operating budget and capital plan - FY 2014.

Retrieved December 12, 2014, from http://cfo.dc.gov/page/annual-operating-budget-andcapital-plan-2013pdfs

District of Columbia. (n.d.-b). Great streets. Retrieved December 13, 2014, from http://greatstreets.dc.gov/

Elias, A. (2011). Key factors affecting multimodal level of service. In Transportation Research Board 90th annual MEETING, Washington, DC. Retrieved November 26, 2014, from http://www.kittelson.com/system/images/122/original/Key Factors Affecting MMLOS FI NAL 11-14-10.pdf

Federal Highway Administration. (2013, November 12). Interim program guidance under MAP-21. Federal Highway Administration. Retrieved January 4, 2014, from http://www.fhwa.dot.gov/environment/air_quality/cmaq/policy_and_guidance/2013_guida nce/index.cfm

Federal Highway Administration. (2013, November 21). Federal-aid highway program funding for pedestrian and bicycle facilities and programs. Retrieved January 14, 2014, from http://www.fhwa.dot.gov/environment/bicycle pedestrian/funding/bipedfund.cfm

Federal Highway Administration. (2014, July 1). Integrating context sensitive solutions in transportation planning. Retrieved November 27, 2014, from http://www.fhwa.dot.gov/planning/csstp/

Florida Department of Revenue. (2013, December 4). 2014 Fuel tax rates. Retrieved November 2, 2014, from http://dor.myflorida.com/dor/tips/pdf/13b05-01 chart.pdf

Goldman, T., Corbett, S., \& Wachs, M. (2001). Local option transportation taxes in the United States (part two: "state-by-state findings"). Institute of Transportation Studies. Retrieved November 30, 2013, from http://escholarship.org/uc/item/3tz3c4c0\#page-3

Goldman, T., \& Wachs, M. (2003). A quiet revolution in transportation finance: The rise of local option transportation taxes. Transportation Quarterly, 57, No.1(Winter 2003), 19-32. Retrieved December 9, 2013, from http://escholarship.org/uc/item/2gp4m4xa.pdf

Gopalakrishna, D., Schreffler, E., Vary, D., Friedenfeld, D., Kuhn, B., Dusza, C., Rosas, A. (2012). Integrating demand management into the transportation planning process: a desk reference (No. FHWA-HOP-12-035). Retrieved August 31, 2012, from http://www.ops.fhwa.dot.gov/publications/fhwahop12035/fhwahop12035.pdf

Grant, M. (ICF), D'Ignazio, J. (ICF), \& McKeeman, A. (ICF). (2013). Performance based planning and programming guidebook (No. FHWA-HEP-13-041). Retrieved January 14, 2014, from

http://www.fhwa.dot.gov/planning/performance_based_planning/pbpp_guidebook/page00 .cfm

Handy, S. L., Cao, X., \& Mokhtarian, P. L. (2008). The causal influence of neighborhood design on physical activity within the neighborhood: evidence from Northern California. American Journal of Health Promotion, 22(5), 350-358

Hoene, C. W., \& Pagano, M. A. (2013). Research brief on America's cities. Washington, D.C.. Retrieved May 21, 2014, from http://www.nlc.org/Documents/Find\%20City\%20Solutions/Research\%20Innovation/Finan ce/Final CFC2013.pdf 
Hurst, N. (2013, October 21). Congress eyes Virginia's model for funding transportation projects. Roll Call. Retrieved November 6, 2013, from http://www.rollcall.com/news/congress eyes virginias model for funding transportation projects-228557-1.html

Kelly, N. M. (2014, May 23). Amendment to the Capital Plan FY 2014 - FY 2023. Retrieved November 4, 2014, from http://onesanfrancisco.org/wp-content/uploads/City-Administrator-Transmittal-Letter-forCapital-Plan-Amendment.pdf

Komanoff, C. (2013, February 15). Lessons from London after 10 years of the congestion charge. Retrieved December 16, 2014, from http://www.streetsblog.org/2013/02/15/lessons-fromlondon-after-10-years-of-the-congestion-charge/

Laing, K. (2013, November 15). Bill would eliminate federal transportation funding. TheHill. Text. Retrieved January 12, 2014, from http://thehill.com/blogs/transportationreport/infrastructure/190402-bill-would-eliminate-federal-transportation

League of American Bicyclists. (n.d.). Award database: bicycle friendly America. Retrieved December 9, 2013, from http://www.bikeleague.org/bfa/awards\#community

Lillis, R. (2013, October 22). Council votes to launch bike corrals, plan parklets in Sacramento. The Sacramento Bee. Retrieved November 7, 2013, from http://www.sacbee.com/2013/10/22/5844018/council-votes-launch-bike-corrals.html

Litman, T. (2006). London congestion pricing. Implications for Other Cities. Retrieved December 16, 2014, from http://www.mumbaidp24seven.in/reference/london congestion pricing.pdf

Liu, Z., Wang, S., Qu, X., \& Shiwakoti, N. (2014). Congestion pricing with distance tolls: a review and new developments. In CICTP 2014: Safe, smart and sustainable multimodal transportation systems (pp. 3459-3469). American Society of Civil Engineers. Retrieved December 16, 2014, from http://ascelibrary.org/doi/abs/10.1061/9780784413623.331

Los Angeles County Metropolitan Transportation Authority. (2008, July 24). Proposed one-half cent sales tax for transportation outline of expenditure categories: FY 2010-2039.

Retrieved October 26, 2014, from

http://media.metro.net/measure R/documents/expenditure plan.pdf

Luskin School of Public Affairs. (2012, September). Reclaiming the right of way: A toolkit for creating and implementing parklets. Retrieved December 16, 2014, from http://books.google.com/books?hl=en\&lr=\&id=rfSJAwAAQBAJ\&oi=fnd\&pg=PA295\&dq=\% 22Luskin+School+of+Public\%22+\%22Department+of+Urban\%22+\%22Companion+to+U rban+Design\%22+\%22Luskin+School+of+Public\%22+\%22in+Minority\%22+\%22Departm ent+of+Urban\%22+\%22resident.+Her+books+include\%22+\%22Luskin+School+of+Public \%22+\&ots=2In3GNyhyW \&sig=iqfILICc4B 1TYZI7MK6mazXVn8

May, A. D., Liu, R., Shepherd, S. P., \& Sumalee, A. (2002). The impact of cordon design on the performance of road pricing schemes. Transport Policy, 9(3), 209-220. doi:10.1016/S0967-070X(02)00031-8

Measure R: Traffic relief and rail expansion ordinance (2009). Retrieved October 26, 2014, from http://media.metro.net/measureR/images/ordinance.pdf 
Metro. (2013, October 9). Measure R. Retrieved October 27, 2014, from http://www.metro.net/projects/measurer/

Molenaar, P. C. M., Lerner, R. M., \& Newell, K. M. (2013). Handbook of Developmental Systems Theory and Methodology. Guilford Publications.

Moving ahead for progress in the 21st century act. , Pub. L. No. H.R. 4348 (2012). Retrieved January 4, 2014, from http://www.gpo.gov/fdsys/pkg/BILLS-112hr4348enr/pdf/BILLS-112hr4348enr.pdf

Moving Ahead for Progress in the 21st Century Act (MAP-21). (n.d.). Retrieved January 5, 2014, from http://www.dot.gov/map21

Overtonbroad. (n.d.). The Hampline. Retrieved November 26, 2014, from https://ioby.org/project/hampline

Pearson, S. (2013, October 31). Virginia may charge tolls for $\$ 2$ billion tunnel project. Bloomberg. Retrieved November 7, 2013, from http://www.bloomberg.com/news/2013-10-31/virginiawins-high-court-leave-to-charge-tunnel-tolls.html

Pedestrian and Bicycle Information Center. (n.d.-b). Walk friendly communities. Walkfriendly.org. Retrieved December 9, 2013, from http://www.walkfriendly.org/communities/list.cfm

Peters, S. (2012). Impact fees for complete streets. University of California, Los Angeles. Retrieved October 16, 2013, from http://164.67.121.27/files/Lewis_Center/CompleteStreetsInitiative/Peters_report.pdf

Puentes, R., \& Prince, R. (2003). Fueling transportation finance: a primer on the gas tax. Retrieved November 29, 2013, from http://www.brookings.edu/es/urban/publications/gastax.pdf

Sacramento Area Council of Governments. (2012, March 23). MTP 2035 issue papers: road maintenance. Retrieved December 9, 2013, from h ttp://www.sacog.org/mtp/pdf/MTP2035/lssue\%20Papers/Road\%20Maintenance.pdf

Saelens, B. E., Sallis, J. F., \& Frank, L. D. (2003). Environmental correlates of walking and cycling: findings from the transportation, urban design, and planning literatures. Annals of Behavioral Medicine, 25(2), 80-91.

Sakash, T. (2013, February 6). Deferred care of streets, bike paths creates costly backlog. Davis Enterprise. Retrieved December 9, 2013, from http://www.davisenterprise.com/localnews/city/deferred-care-of-streets-bike-paths-creates-costly-backlog/

San Francisco Municipal Transportation. (2009, June 26). 2009 San Francisco bicycle plan [Text]. Retrieved November 4, 2014, from http://www.sfmta.com/projects-planning/projects/2009-san-francisco-bicycle-plan

San Francisco Municipal Transportation Agency. (2013, April). SFMTA bicycle strategy. Retrieved November 4, 2014, from http://sfmta.com/sites/default/files/BicycleStrategyFinal_0.pdf 
Santa Barbara County Local Transportation Authority. (2012, January 19). An ordinance of the Santa Barbara County Local Transportation Authority implementing the road repair, traffic relief and transportation safety measure. Retrieved October 25, 2014, from http://www.measurea.net/PDFs/Ord\%205\%20as\%20Amended\%20January\%202012\%20 .pdf

Smart Growth America. (2012). Complete streets policy analysis 2011. Retrieved December 8 , 2013, from http://www.smartgrowthamerica.org/documents/cs/resources/cspolicyanalysis.pdf

Smart Growth America. (2013). Complete streets policy adoption (p. 14). Retrieved December 8 , 2013, from http://www.smartgrowthamerica.org/documents/cs/policy/cs-chartallpolicies.pdf

Southworth, M., \& Ben-Joseph, E. (1995). Street standards and the shaping of suburbia. Journal of the American Planning Association, 61(1), 65-81. doi:10.1080/01944369508975620

State of Alaska Department of Transportation \& Public Facilities. (2014, September 16). 2012 2015 Statewide transportation improvement program (STIP). Retrieved October 25, 2014, from http://www.dot.state.ak.us/stwdplng/cip/stip/assets/STIP.pdf

Surface Transportation Program (STP). (2013, September 12). Retrieved January 14, 2014, from http://www.fhwa.dot.gov/map21/factsheets/stp.cfm

Title 23, United States code. , Title 23, U.S.C. (2012). Retrieved January 4, 2014, from http://www.fhwa.dot.gov/map21/docs/title23usc.pdf

Transport for London. (2008, July). Impacts monitoring. Retrieved December 16, 2014, from http://www.tfl.gov.uk/cdn/static/cms/documents/central-london-congestion-chargingimpacts-monitoring-sixth-annual-report.pdf

Transportation Research Board. (n.d.). Highway Capacity Manual 2010. Retrieved November 27, 2014, from http://hcm.trb.org/?qr=1

U.S. Census Bureau; 2008-2012 DP03-Selected Economic Characteristics-Charlottesville city, Virginia: 5-Year American Community Survey; Table DP03: Retrieved March 17, 2014 from http://factfinder2.census.gov/faces/nav/isf/pages/index.xhtml

U.S. Census Bureau; 2008-2012 DP03-Selected Economic Characteristics-Fort Collins city, Colorado: 5-Year American Community Survey; Table DP03: Retrieved March 15, 2014 from http://factfinder2.census.gov/faces/nav/jsf/pages/index.xhtml

U.S. Census Bureau; 2008-2012 DP03-Selected Economic Characteristics-Gainesville city, Florida: 5-Year American Community Survey; Table DP03: Retrieved February 19, 2014 from http://factfinder2.census.gov/faces/nav/jsf/pages/index.xhtml

U.S. Census Bureau; 2008-2012 DP03-Selected Economic Characteristics- Juneau city and borough, Alaska: 5-Year American Community Survey; Table DP03: Retrieved March 8, 2014 from http://factfinder2.census.gov/faces/nav/jsf/pages/index.xhtml

U.S. Census Bureau; 2008-2012 DP03-Selected Economic Characteristics-Long Beach city, California: 5-Year American Community Survey; Table DP03: Retrieved March 9, 2014 from http://factfinder2.census.gov/faces/nav/isf/pages/index.xhtml 
U.S. Census Bureau; 2008-2012 DP03-Selected Economic Characteristics-Minneapolis city, Minnesota: 5-Year American Community Survey; Table DP03: Retrieved February 20, 2014 from http://factfinder2.census.gov/faces/nav/jsf/pages/index.xhtml

U.S. Census Bureau; 2008-2012 DP03-Selected Economic Characteristics-Santa Barbara city, California: 5-Year American Community Survey; Table DP03: Retrieved February 23, 2014 from http://factfinder2.census.gov/faces/nav/isf/pages/index.xhtml

U.S. Census Bureau; 2008-2012 DP03-Selected Economic Characteristics-San Francisco city, California: 5-Year American Community Survey; Table DP03: Retrieved February 20, 2014 from http://factfinder2.census.gov/faces/nav/jsf/pages/index.xhtml

U.S. Census Bureau; 2008-2012 DP03-Selected Economic Characteristics-Santa Monica city, California: 5-Year American Community Survey; Table DP03: Retrieved February 23, 2014 from http://factfinder2.census.gov/faces/nav/isf/pages/index.xhtml

U.S. Census Bureau; 2008-2012 DP03-Selected Economic Characteristics-Shorewood Village, Wisconsin: 5-Year American Community Survey; Table DP03: Retrieved March 15, 2014 from http://factfinder2.census.gov/faces/nav/jsf/pages/index.xhtml

U.S. Census Bureau; 2008-2012 DP03-Selected Economic Characteristics-Washington city, District of Columbia: 5-Year American Community Survey; Table DP03: Retrieved February 20, 2014 from http://factfinder2.census.gov/faces/nav/isf/pages/index.xhtml

U.S. Census Bureau; 2010 DP-1-Geography-Charlottesville city, Virginia: Profile of General Population and Housing Characteristics; Table DP-1: Retrieved March 17, 2014 from http://factfinder2.census.gov/faces/nav/jsf/pages/index.xhtml

U.S. Census Bureau; 2010 DP-1-Geography-Fort Collins city, Colorado: Profile of General Population and Housing Characteristics; Table DP-1: Retrieved March 15, 2014 from http://factfinder2.census.gov/faces/nav/jsf/pages/index.xhtml

U.S. Census Bureau; 2010 DP-1-Geography-Gainesville city, Florida: Profile of General Population and Housing Characteristics; Table DP-1: Retrieved March 1, 2014 from http://factfinder2.census.gov/faces/nav/jsf/pages/index.xhtml

U.S. Census Bureau; 2010 DP-1-Geography-Juneau city and borough, Alaska: Profile of General Population and Housing Characteristics; Table DP-1: Retrieved March 8, 2014 from http://factfinder2.census.gov/faces/nav/jsf/pages/index.xhtml

U.S. Census Bureau; 2010 DP-1-Geography-Long Beach city, California: Profile of General Population and Housing Characteristics; Table DP-1: Retrieved March 9, 2014 from http://factfinder2.census.gov/faces/nav/isf/pages/index.xhtml

U.S. Census Bureau; 2010 DP-1-Geography-Minneapolis city, Minnesota: Profile of General Population and Housing Characteristics; Table DP-1: Retrieved February 20, 2014 from http://factfinder2.census.gov/faces/nav/jsf/pages/index.xhtml

U.S. Census Bureau; 2010 DP-1-Geography-Santa Barbara city, California: Profile of General Population and Housing Characteristics; Table DP-1: Retrieved February 23, 2014 from http://factfinder2.census.gov/faces/nav/isf/pages/index.xhtml

U.S. Census Bureau; 2010 DP-1-Geography-San Francisco city, California: Profile of General Population and Housing Characteristics; Table DP-1: Retrieved February 20, 2014 from http://factfinder2.census.gov/faces/nav/jsf/pages/index.xhtml 
U.S. Census Bureau; 2010 DP-1-Geography-Santa Monica city, California: Profile of General Population and Housing Characteristics; Table DP-1: Retrieved February 23, 2014 from http://factfinder2.census.gov/faces/nav/jsf/pages/index.xhtml

U.S. Census Bureau; 2010 DP-1-Geography-Shorewood Village, Wisconsin: Profile of General Population and Housing Characteristics; Table DP-1: Retrieved March 15, 2014 from http://factfinder2.census.gov/faces/nav/isf/pages/index.xhtml

U.S. Census Bureau; 2010 DP-1-Geography-Washington city, District of Columbia: Profile of General Population and Housing Characteristics; Table DP-1: Retrieved February 20, 2014 from http://factfinder2.census.gov/faces/nav/jsf/pages/index.xhtml

U.S. Department of Transportation. (2011). Uses of Surface Transportation Program funds for projects not on the national highway system, by improvement category 1/Fiscal year 2011 obligations of federal funds. Retrieved November 29, 2013, from http://www.fhwa.dot.gov/policyinformation/statistics/2011/pdf/stp1.pdf

U.S. Geological Survey. (n.d.). Retrieved December 8, 2013, from http://www.usgs.gov/

U.S. Department of Commerce, N. (n.d.). National Oceanic and Atmospheric Administration (NOAA) Home Page. Retrieved December 8, 2013, from http://www.noaa.gov/

U.S. Department of Transportation. (2013, August 14). Moving ahead for progress in the 21st century act (MAP-21). United States Department of Transportation. Retrieved January 4, 2014, from http://www.dot.gov/map21

Village of Shorewood. (2011a, January 18). Comprehensive plan: Transportation element. Retrieved November 16, 2014, from http://www.villageofshorewood.org/DocumentCenter/Home/View/1068

Village of Shorewood. (2011b, March 3). Comprehensive bike study. Retrieved November 16, 2014, from http://www.villageofshorewood.org/documentcenter/view/241

Village of Shorewood. (2011c, June 8). Tax incremental district no.1, project plan amendment no. 3. Retrieved November 23, 2104, from http://www.villageofshorewood.org/DocumentCenter/View/1867

Village of Shorewood. (2012, June 18). Sustainable Shorewood: Sustainability action plan. Retrieved November 26, 2014, from http://www.villageofshorewood.org/DocumentCenter/View/1536

Village of Shorewood. (2013, November 18). 2014 Budget. Retrieved from http://www.villageofshorewood.org/documentcenter/view/428

Village of Shorewood. (2014a, August 25). Central district master plan. Retrieved November 3 , 2014, from http://www.villageofshorewood.org/documentcenter/view/1997

Village of Shorewood. (n.d.). Tax increment districts. Retrieved November 23, 2014, from http://www.villageofshorewood.org/563/Tax-Increment-Districts 